\title{
EFEITOS DA CONCENTRAÇÃO DE MATÉRIA SECA E DO USO DE INOCULANTE BACTERIANO-ENZIMÁTICO, NA SILAGEM DE TIFTON 85 (Cynodon spp.), SOBRE A DIGESTÃO DE NUTRIENTES, PARÂMETROS RUMINAIS E COMPORTAMENTO INGESTIVO EM NOVILHOS DE CORTE EM CRESCIMENTO
}

RODRIGO MICHELINI COELHO

Dissertação apresentada à Escola Superior de Agricultura "Luiz de Queiroz", Universidade de São Paulo, para obtenção do título de Mestre em Agronomia, Área de Concentração: Ciência Animal e Pastagens.

P I R A C I C A B A

Estado de São Paulo - Brasil

Julho -2002 


\title{
EFEITOS DA CONCENTRAÇÃO DE MATÉRIA SECA E DO USO DE INOCULANTE BACTERIANO-ENZIMÁTICO, NA SILAGEM DE TIFTON 85 (Cynodon spp.), SOBRE A DIGESTÃO DE NUTRIENTES, PARÂMETROS RUMINAIS E COMPORTAMENTO INGESTIVO EM NOVILHOS DE CORTE EM CRESCIMENTO
}

\section{RODRIGO MICHELINI COELHO}

\author{
Zootecnista
}

Orientador: Prof. Dr. LUIZ GUSTAVO NUSSIO

\author{
Dissertação apresentada à Escola Superior \\ de Agricultura "Luiz de Queiroz", \\ Universidade de São Paulo, para obtenção \\ do título de Mestre em Agronomia, Área de \\ Concentração: Ciência Animal e Pastagens. \\ P I R A C I C A B A \\ Estado de São Paulo - Brasil \\ Julho -2002
}


Dados Internacionais de Catalogação na Publicação (CIP)
DIVISÃO DE BIBLIOTECA E DOCUMENTAÇÃO - ESALQ/USP

Coelho, Rodrigo Michelini

Efeitos da concentração de matéria seca e do uso de inoculante bacteriano-enzimático, na silagem de Tifton 85 (Cynodon spp.), sobre a digestão de nutrientes, parâmetros ruminais e comportamento ingestivo em novilhos de corte em crescimento / Rodrigo Michelini Coelho. - - Piracicaba, 2002.

$122 \mathrm{p}$.

Dissertação (mestrado) - - Escola Superior de Agricultura Luiz de Queiroz, 2002.

Bibliografia.

1. Aditivos alimentares para animal 2. Cinodonte 3. Crescimento animal 4. Digestibilidade 5. Ensilagem 6. Forragem - Conservação I. Título

CDD 636.2085

"Permitida a cópia total ou parcial deste documento, desde que citada a fonte - $O$ autor" 


\begin{abstract}
"Porque vocês não sabem do lixo ocidental não precisam mais temer não precisam da solidão todo dia é dia de viver
\end{abstract}

$$
\begin{gathered}
\text { Porque você não verá } \\
\text { meu lado ocidental } \\
\text { não precisa medo não } \\
\text { não precisa da timidez } \\
\text { todo dia é dia de viver }
\end{gathered}
$$

\title{
Eu sou da América do Sul
}

eu sei vocês não vão saber mas agora eu sou "cowboy" sou do ouro, eu sou vocês sou do mundo, sou Minas Gerais" (Lô Borges, Márcio Borges e Fernando Brant) 
Aos meus pais, Lucas e Maria Helena, meus irmãos Lucas, Marcus e Márcio, minha família. Pela força e carinho que sempre me deram em todos os momentos da minha caminhada. 


\section{AGRADECIMENTOS}

À Andrea Brasil José pelo carisma, solidariedade e companheirismo durante a travessia de todos os momentos difíceis da elaboração desta dissertação.

Ao Prof. Dr. Luiz Gustavo Nussio pela orientação na elaboração do projeto, condução do experimento, análises laboratoriais e redação da dissertação.

Ao Dr. José Manuel de Corrêa Simas pelo auxílio na elaboração do projeto, condução do experimento, análises laboratoriais e, principalmente, pela grande amizade.

Ao colega de curso Flávio Geraldo Ferreira Castro pela amizade e auxílio na condução do experimento, análises laboratoriais.

À colega de curso Carla Maris Bittar Nussio pela amizade e auxílio na condução das análises laboratoriais.

Ao colega Fábio Prudêncio pela amizade e apoio durante a conclusão da dissertação.

Ao Professor Irineu Packer, Cláudio de Melo e Érica Baron, pela grande colaboração na condução das análises estatísticas.

Aos meus companheiros de caminhada: Simone Gisele, Francisco Dias, Mário Márcio e Ricardo Manzano, por sempre me proporcionarem momentos de alegria.

Aos professores e funcionários do Departamento de Produção Animal da ESALQ/USP que contribuíram de alguma forma para a realização do presente trabalho. 
Ao funcionário Carlos César Alves do Laboratório de Bromatologia do Departamento de Produção Animal da ESALQ/USP, pela orientação e ajuda na realização das análises laboratoriais.

Ao amigos e companheiros do grupo de trabalho e pesquisa, por toda colaboração e amizade nas horas de descontração: Lucas, Daniele, Solidete, Maurício, André e Rodrigo.

Aos estagiários de Clube de Práticas Zootécnicas (CPZ/ESALQ/USP) pelo auxílio na condução do experimento.

A Fazenda Água Comprida que possibilitou a realização do experimento.

A CAPES pela concessão da bolsa de estudos. 


\section{SUMÁRIO}

\section{Página}

LISTA DE FIGURAS............................................................ ix

LISTA DE TABELAS............................................................. xii

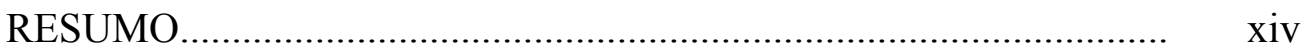

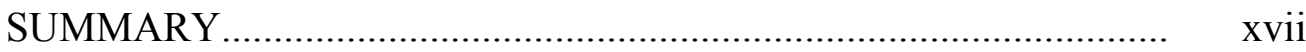

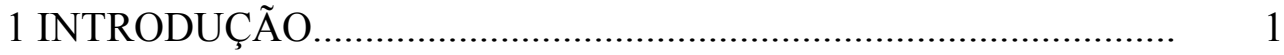

2 REVISÃO DE LITERATURA.................................................... 3

2.1 Estacionalidade de produção das plantas forrageiras e a necessidade de estratégias conservacionistas..................................... 3

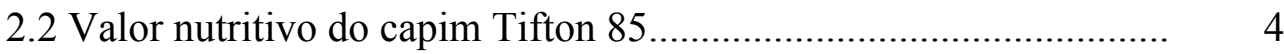

2.3 Adequação de gramíneas tropicais ao processo de ensilagem......... 6

2.4 Emurchecimento................................................................. 9

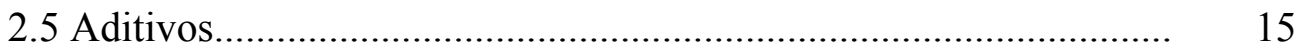

2.5.1 Inoculantes bacterianos...................................................... 16

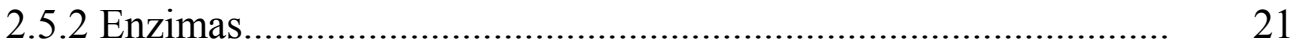

2.6 Vedação do silo...................................................................... 26

2.7 Fatores que interferem na resposta animal................................... 27

2.7.1 Consumo de matéria seca......................................................... 27

2.7.2 Parâmetros microbiológicos do rúmen........................................ 29 
2.7.3 Aspectos da cinética ruminal........................................................ 30

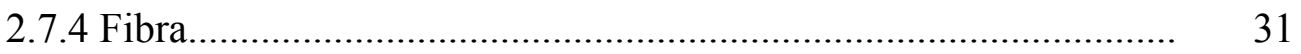

2.7.5 Proteína...................................................................................... 34

3 MATERIAL E MÉTODOS.......................................................... 36

3.1 Local do experimento........................................................... 36

3.1.1 Condução agronômica................................................................... 36

3.2 Confecção da silagem emurchecida................................................ 37

3.3 Período experimental, animais utilizados e ração teste..................... 39

3.4 Comportamento ingestivo........................................................... 42

3.5 Determinação do consistência do conteúdo ruminal (Mat).............. 43

3.6 Parâmetros ruminais........................................................................ 43

3.7 Avaliação da taxa de passagem....................................................... 45

3.8 Avaliação da digestibilidade aparente.................................................. 46

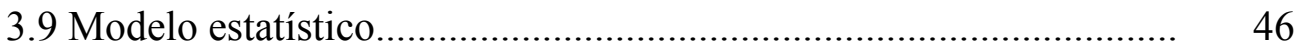

4 RESULTADOS E DISCUSSÃO....................................................... 48

4.1 Composição bromatológica das rações experimentais...................... 48

4.2 Eficiência de utilização das silagens................................................ 54

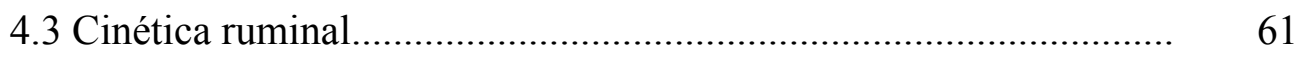

4.3.1 Consistência Ruminal.................................................................. 61

4.3.2 Taxa de passagem........................................................................ 66

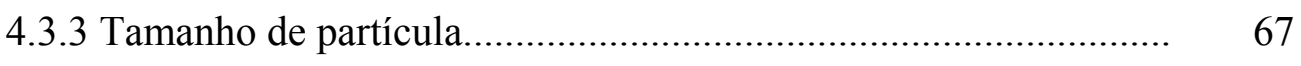

4.4 Comportamento do animal............................................................. 68

4.5 Ingestão de matéria seca...............................................................

4.6 Parâmetros Ruminais..................................................................... $\quad 80$

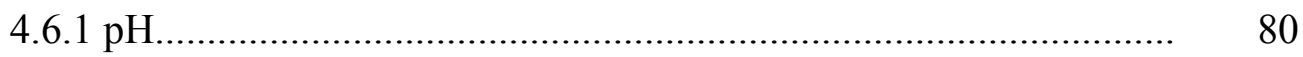

4.6.1.1 Evolução temporal sobre a concentração do $\mathrm{pH}$......................... $\quad 84$

4.6.2 Ácidos graxos voláteis............................................................... 85

4.6.2.1 Evolução temporal da concentração de ácidos graxos voláteis.. $\quad 87$

4.6.3 Nitrogênio amoniacal.................................................................... 91 
4.6.3.1 Evolução temporal sobre a concentração de nitrogênio

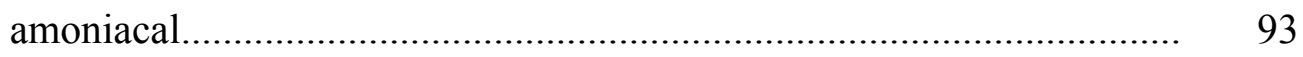

4.7 Digestibilidade aparente no trato digestivo.................................. 94

5 CONCLUSÕES.................................................................... 100

REFERÊNCIAS BIBLIOGRÁFICAS........................................... 102 


\section{LISTA DE FIGURAS}

Página

1 Porcentagem de perdas em matéria seca nos fardos contendo silagens de capim Tifton 85 comparadas sob o efeito de aditivo bacteriano-enzimático e de concentrações de MS.

2 Quantidade $(\mathrm{kg})$ de matéria seca útil, perdida e total contida nos fardos tratados com inoculante bacteriano-enzimático sob diferentes concentrações de MS

3 Quantidade $(\mathrm{kg})$ de matéria seca útil, perdida e total contida nos fardos não tratados com inoculante bacteriano-enzimático sob diferentes concentrações de MS

4 Quantidade $(\mathrm{kg})$ de matéria natural útil, perdida e total contida nos fardos não tratados com inoculante bacteriano-enzimático sob diferentes concentrações de MS. 
5 Quantidade $(\mathrm{kg})$ de matéria natural útil, perdida e total contida nos fardos tratados com inoculante bacteriano-enzimático sob diferentes concentrações de MS.

6 Efeito das dietas experimentais sobre a evolução diária do $\mathrm{pH}$, no fluido ruminal.

7 Efeito das dietas experimentais sobre a evolução diária da concentração molar de ácidos graxos voláteis totais, no fluido ruminal.

8 Efeito das dietas experimentais sobre a evolução diária da concentração molar de ácido acético, no fluido ruminal

9 Efeito das dietas experimentais sobre a evolução diária da concentração molar de ácido propiônico, no fluido ruminal

10 Efeito das dietas experimentais sobre a evolução diária da concentração molar da relação ácido acético:propiônico, no fluido ruminal

11 Efeito das dietas experimentais sobre a evolução diária da concentração molar de ácido butírico, no fluido ruminal

12 Efeito das dietas experimentais sobre a evolução diária da concentração molar de ácido isobutírico, no fluido ruminal

13 Efeito das dietas experimentais sobre a evolução diária da concentração molar de ácido valérico, no fluido ruminal. 
14 Efeito das dietas experimentais sobre a evolução diária da concentração molar de ácido isovalérico, no fluido ruminal..............................................................

15 Efeito das dietas experimentais sobre a evolução diária da concentração de nitrogênio amoniacal, no fluido ruminal............................................................. 


\section{LISTA DE TABELAS}

1 Valores relativos às medidas do peso, volume e densidade dos fardos

Página avaliados no experimento com ou sem aditivo bacteriano-enzimático......

2 Composição percentual da ração experimental oferecida aos animais.........

3 Médias das variáveis de composição bromatológica observadas para ingredientes concentrados e para as silagens de capim Tifton 85 .

4 Médias dos quadrados mínimos para as variáveis de eficiência de utilização de fardos contendo silagens de capim Tifton 85

5 Médias dos quadrados mínimos para variáveis de cinética ruminal observadas em bovinos e caracterização física de frações contendo silagens de capim Tifton 85 
6 Médias dos quadrados mínimos para as variáveis de comportamento ingestivo de bovinos recebendo rações contendo silagens de capim Tifton 85

7 Médias dos quadrados mínimos para o consumo de matéria seca e ingestão de FDN observado em bovinos recebendo rações contendo silagens de capim Tifton 85 .

8 Médias dos quadrados mínimos para as variáveis ruminais observadas em bovinos recebendo rações contendo silagens de capim Tifton 85

9 Evolução temporal das médias dos quadrados mínimos para as variáveis ruminais observadas em bovinos recebendo rações contendo silagens de

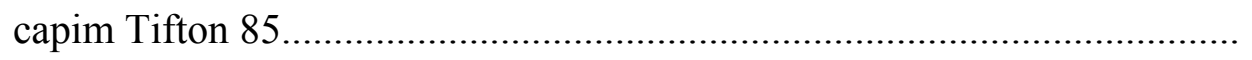

10 Médias dos quadrados mínimos para os coeficientes de digestibilidade, NDT estimado e ingestão de nutrientes digestíveis para matéria seca, matéria orgânica, proteína bruta, FDN, FDA e hemicelulose em rações contendo silagens de capim Tifton 85 


\section{EFEITOS DA CONCENTRAÇÃO DE MATÉRIA SECA E DO USO DE INOCULANTE BACTERIANO-ENZIMÁTICO, NA SILAGEM DE TIFTON 85 (Cynodon spp.), SOBRE A DIGESTÃO DE NUTRIENTES, PARÂMETROS RUMINAIS E COMPORTAMENTO INGESTIVO EM NOVILHOS DE CORTE EM CRESCIMENTO}

Autor: RODRIGO MICHELINI COELHO Orientador: Prof. Dr. LUIZ GUSTAVO NUSSIO

\section{RESUMO}

O presente trabalho teve como objetivo avaliar o efeito do emurchecimento da forragem associado ou não ao uso do aditivo bacteriano-enzimático na ensilagem do capim Tifton 85 (Cynodon spp.). Foi realizada avaliação de perdas nos painéis das silagens experimentais, assim como da composição bromatológica e do tamanho de partículas das mesmas. Ocorreram observações periódicas de comportamento ingestivo, consistência ruminal, consumo voluntário, parâmetros de fermentação ruminal, digestibilidade dos nutrientes, taxa de passagem de sólidos e líquidos ruminais em novilhos que receberam rações contendo $80 \%$ desses volumosos na base seca. Foram utilizados sete novilhos da raça Nelore, distribuídos ao acaso em um experimento do tipo quadrado latino $7 \times 7$. Os tratamentos avaliados foram resultantes da combinação de 3 concentrações de matéria seca (MS) na silagem do capim Tifton 85 (25, 45 e 65\%) 
associadas (CA) ou não (SA) ao aditivo bacteriano-enzimático. Um tratamento adicional contendo 55\% MS sem aditivo também foi avaliado. $\mathrm{O}$ aditivo utilizado foi o produto comercial SIL-ALL ${ }^{\circledR}$, contendo cepas de Streptococcus faecium, Lactobacillus plantarum, Pediococcus acidilactici e as enzimas hemicelulase, celulase e amilase, aplicadas na dosagem de $250 \mathrm{~g}$ de SIL-ALL ${ }^{\circledR}$ diluídas em 50 litros de água por tonelada de forragem, imediatamente antes da ensilagem. A técnica de emurchecimento possibilitou elevar o teor de matéria seca mas, da mesma maneira que a adição do inoculante bacteriano-enzimático, provocou alterações pouco pronunciadas na composição química da silagem. Nas silagens SA o aumento da concentração de MS foi acompanhado de elevação no teor de FDN resultando em redução do teor de carboidratos não fibrosos (CNF). A fração protéica $\mathrm{B}_{3}$ nas silagens apresentou tendência de aumento com a elevação na concentração de MS, em função da progressiva elevação da fração $\mathrm{N}$ insolúvel no $\mathrm{FDN}$, simultaneamente à redução $\mathrm{N}$ insolúvel no FDA. $\mathrm{A}$ avaliação dos silos após abertura, indicou aumento de perdas com a elevação da concentração de MS que, entretanto, podem ter sido decorrentes de uma menor taxa de utilização dos fardos contendo silagens com menor umidade. Tanto a consistência ruminal, avaliada como o tempo de ascensão do pêndulo no interior do rúmen (1194 seg.), como os parâmetros de cinética de passagem de sólidos $\left(3,09 \%\right.$ hora $\left.^{-1}\right)$ e de líquidos $\left(4,37 \%\right.$ hora $\left.^{-1}\right)$ foram similares para os tratamentos avaliados. O comportamento ingestivo dos animais não foi alterado com a elevação da concentração de MS da silagem, sendo observados tempos (minutos $\mathrm{dia}^{-1}$ ) e taxas $\left(\operatorname{min~} \mathrm{kg} \mathrm{MS}^{-1}\right)$ de ingestão de MS $(324 ; 47)$, ruminação $(518 ; 75)$ e mastigação $(841 ; 123)$, respectivamente. O consumo diário de MS das rações, pelos animais, foi semelhante para os tratamentos avaliados, resultando em média de $6,95 \mathrm{~kg}$ equivalente a 1,88\% do peso corpóreo. As concentrações molares (mM) individuais e totais $(140,29)$ dos ácidos graxos voláteis, a relação acetato:propionato $(4,2: 1)$, concentração de nitrogênio amoniacal $\left(6,31 \mathrm{mg} \mathrm{dL}^{-1}\right)$ e o $\mathrm{pH}(6,76)$, do fluido ruminal, não foram alterados pelos tratamentos estudados. As digestibilidades da matéria orgânica $(71,5 \%)$, proteína bruta $(69,1 \%)$, FDN $(71,3 \%)$, FDA $(64,9 \%)$ e hemicelulose $(83,3 \%)$ não foram, em geral, fortemente influenciadas pela concentração de MS da silagem do capim Tifton 85 , aditivadas ou não. No entanto, 
a digestibilidade da MS $(71,0 \%)$ apresentou um comportamento quadrático $(\mathrm{P}<0,05)$, com ligeira elevação ao redor de $45 \%$ de concentração de MS, nas silagens. Diante destas observações, pode-se concluir que o emurchecimento da forragem e o uso de aditivo bacteriano-enzimático não resultaram em alterações expressivas nos parâmetros ruminais, digestivos e no comportamento ingestivo dos animais. 


\section{EFFECTS OF THE DRY MATTER CONCENTRATION AND USE OF \\ BACTERIAL-ENZYMATIC INOCULANT, IN TIFTON 85 (Cynodon spp.) SILAGE, ON THE NUTRIENT DIGESTION, RUMINAL PARAMETERS AND INGESTIVE BEHAVIOR IN GROWING BEEF STEERS.}

Author: RODRIGO MICHELINI COELHO Adviser: Prof. Dr. LUIZ GUSTAVO NUSSIO

\section{SUMMARY}

The present trial aimed to study the effects of forage wilting associated or not with a bacterial-enzymatic inoculant on ensiling Tifton 85 grass. Front panel of experimental silos (325 kg square wrapped bales) were daily scored for fungi development and weekly sampled for chemical composition analysis and particle chop length measurements. In a randomized 7 × 7 Latin square design, seven ruminal cannulated growing beef steers were assigned to diets (treatments) containing 80\% silage. Periodically chewing behavior, feed intake, ruminal mat consistency, ruminal fermentation parameters, nutrient digestibility and ruminal rate of passage of solids and liquids phases were evaluated. Treatments combined 3 planned dry matter (DM) concentrations $(25,45$ and $65 \%)$ of Tifton 85 grass silage associated (CA) or not (SA) with the bacterial-enzymatic (BE) inoculant source. An additional treatment containing 
wilted silage $(55 \% \mathrm{DM})$ without $(\mathrm{BE})$ was also studied. SIL-ALL ${ }^{\circledR}$, the BE source used, was sprayed onto chopped forage just before silage packing at a rate of $250 \mathrm{~g}$ diluted in $50 \mathrm{~L}$ of deionized water per ton of wet forage. The commercial BE showed the following composition: Streptococus faecium, Lactobacillus plantarum, Pediococcus acidilactici plus hemicellulase, cellulase and starch degrading enzymes. The wilting of forage allowed to increase the DM concentration of silages, however, as well as BE addition, it was not effective to promote major changes on chemical composition of silages. On SA silages, higher NDF levels were observed as the DM level of the wilted silage increased, which resulted in lower non-fiber carbohydrate (NFC) fraction. The $\mathrm{B}_{3}$ protein fraction (NDIN minus ADIN) showed an increase as the DM concentration of wilted silage was raised, probably as result of an opposite trend between neutral detergent insoluble nitrogen (NDIN) and acid detergent insoluble nitrogen (ADIN) across DM levels. Silage losses, measured as both, fungi scored at bale front panel and percentage of spoiled silage, indicated higher levels associated with increased DM concentration. It might be explained by the lower bale unloading rate observed during the feeding trial, mainly in higher DM wilted silages. Both, ruminal mat consistency, measured as time required to weight ascension into the rumen (1194 sec.) as well as ruminal kinetics, evaluated as passage rate of solid $\left(3.09 \%\right.$ hour $\left.^{-1}\right)$ and liquid $\left(4.37 \%\right.$ hour $\left.^{-1}\right)$ phases were similar for all treatments. Animal ingestive behavior measured as total time (minutes day ${ }^{-1}$ ) and rate (minutes $\mathrm{DM} \mathrm{kg}{ }^{-1}$ ) was not changed across silages DM concentration, averaging DM eating $(324 ; 47)$, DM ruminating $(518 ; 75)$ and DM chewing $(841 ; 123)$, respectively. Residual daily time was spent with drinking and idling activities. The DM intakes observed among experimental diets, containing wilted silages, were not statistically different and averaged $6.95 \mathrm{~kg}^{-1 a y}{ }^{-1}$ or $1.88 \%$ as body weight basis. Individual and total (140.29) molar concentration (mM) of volatile fatty acids (VFA), acetate:propionate ratio $(4,2: 1)$, ammonia- $\mathrm{N}\left(6.31 \mathrm{mg} \mathrm{dL}^{-1}\right)$ and average daily $\mathrm{pH}$ (6.76) of ruminal fluid were similar across silages diets. Nutrient digestibilities were, also, not significantly affected by the increased DM concentration in wilted silages or by the BE inoculation, as follows: organic matter (71.5\%), crude protein (69.1\%), NDF (71.3\%), ADF (64.9\%) and hemicellulose $(83.3 \%)$. DM digestibilities, however, performed a quadratic pattern 
$(\mathrm{P}<0.05)$, with a slight increase at $45 \% \mathrm{DM}$ concentration in silages. According to the results it may be concluded that neither the increase of DM concentration of grass silages nor the addition of bacterial-enzymatic inoculant changed animal ingestive behavior or improved ruminal and digestive parameters analyzed. 


\section{INTRODUÇÃO}

A pecuária nacional passa por uma rápida transformação em que o tradicionalismo cede espaço a uma moderna cadeia produtiva, pressionada por fatores de ordem mercadológica e sanitária. Neste contexto, objetivos devem ser definidos e avaliados especialmente para componentes limitantes do sistema produtivo, que coloquem em risco o sucesso da atividade.

A maioria dos sistemas de produção de ruminantes, no Brasil, são baseados na utilização de forrageiras tropicais, fato que merece relevância, pois a dinâmica de crescimento e produção de biomassa vegetal é controlada por variáveis edafo-climáticas, ocasionando uma produtividade sazonal. Com o intuito de superar períodos críticos, algumas técnicas conservacionistas como ensilagem e/ou fenação passam a ser importantes ferramentas para que os produtos de origem animal sejam competitivos no novo cenário.

O princípio da conservação de forragens, como a ensilagem, é baseado na fermentação anaeróbica, visando fornecer uma quantidade suficiente de ácido lático para inibir microrganismos indesejáveis, bem como a atividade endógena de enzimas catalíticas, com o objetivo de manter as características do alimento próximas ao original.

Historicamente, o capim elefante (Pennisetum purpureum, Schum) foi a primeira gramínea tropical perene de interesse para ensilagem, por apresentar elevado potencial de produtividade de matéria seca, quando bem manejada, e por se estabelecer em muitas regiões do país. Recentemente, com o aparecimento de novas introduções de gramíneas

dos gêneros Brachiaria, Cynodon, Panicum e Pennisetum cresceu o interesse pela exploração destas, nas propriedades onde se pratica a conservação de forragens. 
Entretanto, o elevado teor de umidade contido nas plantas, no momento da ensilagem, favorece o desenvolvimento de microrganismos indesejáveis, perdas por efluente, alterações nas frações protéicas e redução no consumo voluntário de matéria seca. Devido a necessidade de se atenuar este efeito, a técnica do emurchecimento tem se mostrado como um método eficiente na elevação do teor de matéria seca. Contudo, é fundamental que os processos mecanizados associados ao emurchecimento procurem evitar perdas na captação da forragem, no campo.

Ultimamente, com os avanços tecnológicos no setor agro-industrial, surgiram inoculantes bacterianos-enzimáticos com a finalidade de melhorar o padrão fermentativo e preservação de silagens e, consequentemente, melhora do desempenho animal. Entretanto, seu efeito tem sido contraditório em inúmeros trabalhos realizados.

São objetivos gerais desta investigação determinar se o emurchecimento e o uso de aditivo bacteriano-enzimático na ensilagem de capim Tifton 85 (Cynodon spp.) alteram os parâmetros de fermentação ruminal, o consumo voluntário de matéria seca, digestibilidade dos nutrientes, parâmetros de cinética ruminal e comportamento ingestivo de novilhos Nelore, em crescimento, bem como a avaliação das perdas nas silagens, após abertura dos fardos ensilados. 


\section{REVISÃO DE LITERATURA}

\subsection{Estacionalidade de produção das plantas forrageiras e a necessidade de estratégias conservacionistas}

A maioria dos sistemas de produção de animais ruminantes, no Brasil, são baseados na utilização de forrageiras tropicais perenes. A eficiência produtiva e econômica deste tipo de exploração torna-se dependente das condições climáticas intrínsecas às estações do ano, pois a deficiência ou abundância dos recursos naturais determinam o ritmo de crescimento vegetal, principal componente alimentar na dieta de bovinos, ovinos e caprinos.

Estudos sobre a dinâmica de crescimento e acúmulo de matéria seca em pastagens, apontam para uma distribuição desuniforme de produção forrageira, perfazendo 75 a $85 \%$ do total no verão e 25 a $30 \%$ no inverno, indicando grande estacionalidade e potencial para conservação, através da ensilagem e/ou fenação.

A fenação é um processo de conservação baseado na desidratação, em que a forragem depois de cortada é disposta, nos processos tradicionais, em camadas sobre o terreno, sendo mais tarde revolvida o quanto for necessário, para que a perda de umidade se processe com regularidade conveniente.

É importante salientar que nas condições climáticas do Brasil Central, durante os meses de verão, observa-se que há ocorrência de $50 \%$ de dias propícios à secagem do material, no campo, ou seja com ausência de chuvas, temperatura elevada, umidade relativa baixa e ocorrência de ventos (Reis \& Rodrigues, 1998).

Segundo de Faria (1994) a aceitação desta suposição, contribuiu para que as técni- 
cas de produção de fenos fossem relegadas a plano secundário ou então executadas no início da época seca.

O objetivo da ensilagem é a preservação da forragem pela estimulação da fermentação lática através da população de bactérias epifíticas produtoras de ácido lático (BAL), as quais proporcionam uma rápida redução do $\mathrm{pH}$, minimizando mudanças no valor nutritivo da planta (Davies et al., 1996). As silagens de gramíneas tropicais perenes passaram a ter projeção em planos nutricionais, nos últimos anos, devido ao surgimento ou melhoria das condições de colheita e processamento físico, da forragem, na estocagem. Os principais avanços tecnológicos que levaram a melhoria do sistema de conservação de forragens são descritos como sendo: melhoramento genético de plantas forrageiras associado às práticas de manejo de pastagens, surgimento de equipamentos de colheita com desempenho favorável, redução da área de plantio, custo e risco quando comparada à cultura tradicional, como a do milho.

Da necessidade de buscar mecanismos viáveis para produção de volumosos em quantidade e com qualidade no verão, a silagem emurchecida surge como alternativa para programas exclusivos de fenação. A técnica do emurchecimento possibilita a ensilagem de plantas forrageiras, com teor de matéria seca intermediário, num processo em que as fermentações indesejáveis são controladas através da diminuição da atividade da água ou elevação da pressão osmótica (McDonald et al., 1991).

\subsection{Valor nutritivo do capim Tifton 85}

O valor nutritivo dos alimentos é um tanto complexo para ser definido mas, para a maioria dos nutricionistas, ele envolve três componentes básicos: digestibilidade, eficiência energética e consumo (Mattos, 1992).

A exploração do potencial de silagens, como alimento para ruminantes, depende do consumo de matéria seca e valor nutritivo (Thomas \& Chamberlain, 1992). Segundo Erdman (1993), o consumo de matéria seca é influenciado diretamente pela porcentagem de umidade do material armazenado, onde o baixo teor de matéria seca na forragem afeta negativamente o consumo, sendo os subprodutos das fermentações secundárias 
responsáveis pelos efeitos observados. O valor nutritivo é determinado pelo conteúdo de nutrientes da silagem, pela sua disponibilidade e eficiência de utilização pelos animais em condições de manutenção, crescimento, lactação e gestação (Thomas \& Chamberlain, 1992).

A conservação de forragem produzida no verão, para fornecimento durante o inverno é possível com plantas do gênero Cynodon. Esta prática, quando executada adequadamente poderá produzir alimentos volumosos de valor nutritivo elevado compatível às alternativas tradicionais (Corsi \& Marta, 1998).

O capim bermuda Tifton-85 é um híbrido do PI 290884 da África do Sul com o Tifton 68. É uma planta perene, estolonífera e rizomatosa apresentando colmos e folhas mais finos dos que o capim Tifton 68, e maiores do que os do capim Coastcross 1. Os estolões apresentam coloração verde e pigmentação roxa pouco intensa. É um capim recomendado para fenação e para pastejo em decorrência da boa relação folha/colmo que possui, sendo aceito por eqüinos, bovinos, e caprinos (Rodrigues et al., 1998).

O capim Tifton 85 foi selecionado por sua alta produtividade e digestibilidade, quando comparada com a maioria das outras plantas do gênero Cynodon (Pedreira, 1996). Comparando com o Coastal, por exemplo, o Tifton 85 produziu $26 \%$ mais matéria seca e foi $11 \%$ mais digestível (Burton ${ }^{1}$, citado por Pedreira, 1996).

As plantas forrageiras do gênero Cynodon são eficientes produtores de matéria seca superando 20 toneladas $\mathrm{ha}^{-1} \mathrm{ano}^{-1}$, principalmente sob manejo que envolve adubação nitrogenada. Embora as hastes em crescimento desta gramínea, apresentem elevada digestibilidade (75 a $85 \%$ ), a maturação ocorre rapidamente e com isso a digestibilidade sofre redução para valores próximos de 30\%. Este decréscimo é associado ao aumento no conteúdo de parede celular, que perde valor nutritivo continuamente ao longo da maturação (Nussio et al.,1998).

Ribeiro (2000), avaliando o rendimento forrageiro e o valor nutritivo do Tifton 85, sob diferentes doses de nitrogênio e idades de rebrota, concluiu que: a produtividade variou de 5,751 a 20,466 , de 8,138 a 22,852 e de 10,525 a $25,239 \mathrm{~kg} \mathrm{ha}^{-1}$ ano $^{-1}$ de

${ }^{1}$ BURTON, G.W.; GATES, P.N.; HELL, G.M. Registration of "Tifton 85 " bermudagrass. Crop Science, Madison, v.33, p.644-645, 1993. 
matéria seca, em função das doses de nitrogênio $0,100,200,300$, e $400 \mathrm{~kg} \mathrm{ha}^{-1}$ ano $^{-1}$ colhidas no intervalo de 28, 42 e 56 dias, respectivamente; a relação lâmina/colmo do capim Tifton 85 é considerada intermediária, pois se aproximam de 1, o que corresponde a $50 \%$ de lâminas e $50 \%$ de colmos, tendendo a aumentar com a sucessão de cortes; os rendimentos protéicos do Tifton 85 variaram de $135 \mathrm{~kg} \mathrm{ha}^{-1}$ corte $^{-1}$, quando não adubado e colhido com 56 dias de rebrota, a $633 \mathrm{~kg} \mathrm{ha}^{-1}$ corte $^{-1}$, adubado com $100 \mathrm{~kg} \mathrm{ha}^{-1}$ corte $^{-1}$ de nitrogênio e colhido com 28 dias de rebrota, descritos conforme a equação $\hat{Y}=438,6$ $+3,47 \mathrm{~N}-50,41 \mathrm{I},\left(\mathrm{r}^{2}=0,83\right)$. Em geral, o rendimento de proteína na planta inteira de capim aumentou 3,47 $\mathrm{kg} \mathrm{ha}^{-1}$, para cada quilo de nitrogênio aplicado e decresceu $5,42 \mathrm{~kg}$ $\mathrm{ha}^{-1}$, por dia. Os rendimentos médios de proteína bruta encontrados nos $1^{\mathrm{o}}$ e $3^{\mathrm{o}}$ cortes, foram de 313 e $398 \mathrm{~kg} \mathrm{ha}^{-1}$ ano $^{-1}$, respectivamente; de modo geral, os teores de FDN foram reduzidos com o aumento das doses de nitrogênio e apresentaram incrementos com o avanço da idade da planta, variando de 71,3\% (lâminas) a 87,9\% (colmos), com 28 e 56 dias de idade, respectivamente, na ausência da adubação nitrogenada; os teores de FDA aumentaram, aproximadamente, 0,044 e 0,037 unidades percentuais $\mathrm{kg}^{-1}$ de nitrogênio aplicado, assim os teores de FDA variaram de 40,2 a 48,7\% no colmo e de 38 a 45,3\% na planta inteira. Verificou-se o teor médio de FDA de 38,6\% em lâminas e que os teores de lignina no colmo e na planta inteira aumentaram 0,0021 e 0,0019 unidades percentuais por dia, respectivamente. As doses crescentes de nitrogênio, estimularam a síntese de lignina traduzida por aumentos de 3,96\% em plantas colhidas com 28 dias de rebrota e na ausência de nitrogênio, o valor foi de 7,23\% em plantas colhidas com 56 dias de rebrota, recebendo $100 \mathrm{~kg} \mathrm{ha}^{-1}$ corte $^{-1}$; encontrou-se forte correlação entre os teores de lignina e os coeficientes de DIVMS dos colmos $\left(\mathrm{r}^{2}=0,81\right)$. Contudo, a redução na DIVMS dos colmos não interferiu na DIVMS da planta inteira de Tifton 85.

\subsection{Adequação de gramíneas tropicais ao processo de ensilagem}

Quantidades adequadas de substrato fermentecível (carboidratos solúveis), poder tampão relativamente reduzido e porcentagem de matéria seca acima de $30 \%$ são 
reconhecidas como características importantes na obtenção de padrões desejáveis de fermentação e conservação de forragem, através da ensilagem (McDonald, 1991).

$\mathrm{Na}$ ensilagem de plantas que apresentam teores de matéria seca inferiores a $21 \%$, concentrações de carboidratos solúveis inferiores a 2,2\% na base de matéria verde e associadas à baixa relação entre carboidratos e poder tampão, aumentam os riscos de fermentação secundária, sendo aconselhável a utilização de recursos que atenuem este cenário (Wilkinson ${ }^{2}$ et al., citados por Vilela, 1989). Em situações adversas, deve-se procurar estimular a produção de ácido lático, para inibir a fermentação secundária. Neste caso, a presença de carboidratos solúveis, assim como a população de bactérias láticas, podem auxiliar na obtenção de sucesso, neste processo (Vilela, 1998).

Considerando a importância dos fatores inerentes à forragem tropical deve-se ressaltar que esta apresenta concentração marginal de carboidratos solúveis, na matéria seca, nos estádios de crescimento em que apresenta um bom valor nutritivo (Vilela, 1998, Umanã et al., 1991). Esta característica coloca em risco o processo de conservação, com probabilidade de surgirem fermentações secundárias, refletindo negativamente nas perdas de matéria seca (Vilela, 1998). Limitações dessa natureza, podem ser parcialmente controladas pelo aumento na concentração de matéria seca, através do emurchecimento, ou pela utilização de aditivos que possam contribuir para acelerar e estabilizar a fermentação, como no caso dos inoculantes bacterianos e enzimas.

As plantas forrageiras tropicais, em geral, apresentam níveis elevados de fibra e baixas concentrações de conteúdo celular, que refletem negativamente na sua digestibilidade e, consequentemente, na digestibilidade da silagem. O método de conservação normalmente afeta mais o consumo do que a digestibilidade da forragem. Assim os subprodutos da fermentação, no silo, correlacionam-se negativamente com o consumo de silagem.

\footnotetext{
${ }^{2}$ WILKINSON, J.M.; CHAPMAN, P.F.; WILKNS, R.J.; WILSON,R.F. Interrelations between pattern of fermentation during ensilage and initial crop composition. In: INTERNATIONAL GRASSLAND CONGRESS, 1981. Lexington. Proceedings. Boulden:Westview, 1982. p.631-634.
} 
Um fator que influi na digestibilidade das forrageiras é a temperatura, principalmente a ambiente, onde a cada $10^{\circ} \mathrm{C}$ de aumento na temperatura por unidade de tempo, ocorre decréscimo na digestibilidade, devido à maior lignificação da parede celular da planta, em conseqüência da maior velocidade no metabolismo dos açúcares. Desta forma a qualidade da silagem é duplamente afetada, pela baixa digestibilidade ou pelo baixo teor de carboidratos solúveis que servirá de substrato para microrganismos (Vilela, 1994).

O estádio de maturidade da planta forrageira, na colheita, influencia seu valor nutritivo. A medida que a planta cresce e se desenvolve, os teores de lignina e FDN aumentam, enquanto o teor de proteína bruta e a digestibilidade da matéria seca são reduzidos. As plantas forrageiras maduras apresentam um menor consumo voluntário pelo animal, devido às mudanças estruturais e bromatológicas ocorridas com o avanço da maturidade, que decresce a taxa de digestão, retarda a passagem e, consequentemente, reduz o consumo. Portanto é relevante o conhecimento do momento de colheita, pois a forragem de melhor valor alimentício certamente promoverá maior consumo e desempenho animal (Ribeiro et al., 2001b).

O teor de proteína das forragens tropicais raramente é superior a $12 \%$ e na maioria das vezes os valores são menores que 7\%. Em muitos casos, as silagens de gramíneas tropicais mostram teores de proteína abaixo de $6 \%$, pois estes materiais são ensilados na maior parte das vezes em estádio fisiológico avançado. As plantas tropicais, além de apresentarem baixos teores de proteína, também apresentam baixos teores de nitrogênio como proteína verdadeira (solúvel). A maior parte do nitrogênio nestas gramíneas está relacionado a fração não protéica, porém é provável que isso seja aceitável somente para plantas muito novas, que ainda não tivessem atingido o ponto de ensilagem. Deste modo, plantas aptas a serem ensiladas apresentam as frações associadas à parede celular (N-FDN e N-FDA), em maiores proporções. O N-FDN tem ampla variação entre as análises bromatológicas encontrando-se valores entre 25 a $70 \%$ do nitrogênio total, sendo a maior freqüência na faixa de 40 a 60\% (Balsalobre et al., 2001).

Keady \& O’Kiely (1996), na tentativa de aumentar produção por área, concluíram que o aumento da fertilização nitrogenada proporciona um efeito quadrático na produção 
de plantas forrageiras. Mas este efeito não implica em crescimento da rebrota subsequente. A taxa e extensão do declínio de $\mathrm{pH}$ de plantas ensiladas que receberam doses de nitrogênio foi reduzido com o aumento da aplicação de nitrogênio associado à alta capacidade tampão e decréscimo da concentração de matéria seca da massa ensilada. Estes autores sugeriram que a aplicação de altas doses de nitrogênio pode ter efeito negativo sobre o consumo de silagem e desempenho de animais produzindo carne e leite.

Maiores períodos de descanso para rebrota da forragem estão associados com maiores produtividades de matéria seca. No entanto, plantas de maior idade fisiológica apresentam aumento de proporção de hastes e isto reduz o valor alimentar da forragem, provocando a redução no teor de carboidratos solúveis, que em se tratando de silagem, é prejudicial a boa fermentação (Balsalobre et al., 2001).

Em síntese, uma das possíveis razões do baixo desempenho de animais alimentados com as silagens de gramíneas tropicais perene é o baixo valor nutritivo na idade normalmente recomendada para o seu corte, associado com efeitos fisiológicos provocado pelas interações com o meio ambiente.

\subsection{Emurchecimento}

A técnica do emurchecimento, ou secagem possibilita a ensilagem de forrageiras colhidas com baixo teor de matéria seca, num processo em que as fermentações indesejáveis são controladas através da elevação da pressão osmótica (de Faria \& Corsi, 1992). Com isto, poderá ocorrer aumento no consumo voluntário da silagem e na eficiência de utilização da sua proteína, pelo animal. No entanto, a desidratação da planta dificulta o seu corte em partículas pequenas, bem como a compactação e a exclusão do ar da massa ensilada. A redução no teor de umidade das plantas a serem ensiladas poderá ser realizada através do emurchecimento por exposição ao sol ou pela utilização de aditivos que contenham elevada concentração de matéria seca (Vilela, 1984). Tosi (1997), trabalhando com capim elefante cortado com 48 dias de rebrota, para ensilagem, sob os seguintes tratamentos: 0, 20,30, e 40\% de sabugo de milho 
triturado, emurchecimento por 12 ou 24 horas, e esmagamento mais emurchecimento por 24 horas, verificou a elevação no teor de matéria seca para os tratamentos com adição de 30 e $40 \%$ de sabugo de milho ou com emurchecimento por 24 horas, entretanto houve redução no teor de ácido lático em todos os níveis de inclusão de sabugo, queda na digestibilidade in vitro da matéria seca e ineficiência na limitação da proteólise, bem como o desenvolvimento de clostrídeos. Concluindo, assim, que o tratamento que mais preservou as propriedades químicas e microbiológicas da silagem foi o emurchecimento por 12 horas sem o esmagamento dos talos.

Wilkinson (1985) de acordo com Chamberlain \& Wilkinson (2000), propuseram um período máximo de secagem, no campo, de 24 horas. Pois longos períodos de secagem podem resultar em grandes perdas de matéria seca, principalmente de proteína, alterando a proporção do N-protéico que proporcionará redução no consumo de matéria seca e carboidratos, reduzindo o valor energético da silagem, enquanto curtos períodos proporcionam pequenas perdas pela respiração com aumento significativo na concentração de matéria seca da forragem.

O benefício do emurchecimento, em termos de consumo voluntário pelo animal, é variável de acordo com as condições climáticas ocorridas durante a perda de água, pela forragem. A magnitude de resposta à secagem é correlacionada com a taxa de secagem no campo e aumento na concentração de matéria seca, mais propriamente, do que alteração da composição da matéria seca. O emurchecimento resultou em aumento proporcional no consumo de matéria seca e energia digestível de 0,21 e 0,20, respectivamente, quando comparado com a silagem convencional. Este aumento foi observado no consumo de energia digestível, estimado na matéria seca, para novilhos de corte e na digestibilidade energética obtida por carneiros alimentados ao nível de mantença (Dawson et al., 1999).

Dawson et al. (1999) comparando a secagem artificial e o emurchecimento, não observaram efeito no consumo de matéria seca. Entretanto, a ensilagem direta de gramínea reduziu o consumo em 19\%. O emurchecimento também melhorou o consumo estimado de energia digestível em 7\% quando comparado com a secagem artificial, e para a gramínea ensilada diretamente, houve redução em 11\%. 
A utilização de condicionadores na confecção da silagem emurchecida promove a melhoria na taxa de secagem, como na digestibilidade da forragem seca, mas este dispositivo não se mostrou efetivo na alteração da digestibilidade de nutrientes ou no desempenho de vacas em lactação recebendo alfafa emurchecida (Shinner et al., 2000). Segundo Frost et al. (1995) o emurchecimento tende a reduzir a concentração dos produtos fermentados na silagem, indicado pela discreta redução na concentração de ácidos orgânicos, sendo a desidratação da massa o efeito mais importante, resultante da ação direta do tratamento.

As melhores relações funcionais utilizadas para descrever o aumento do consumo de matéria seca, quando se utiliza a silagem emurchecida, consideram a extensão e taxa de perda da água a campo, $\mathrm{r}^{2}=0,34$ e 0,39 , respectivamente, sendo que o aumento de ambas resulta em aumento do consumo de matéria seca. Das variáveis associadas à fermentação de silagens que não sofreram ação da desidratação, a concentração de Namoniacal foi a que mais se correlacionou com o aumento do consumo de matéria seca $\left(r^{2}=0,24\right)$. Entre outras variáveis com menor importância, mas com significado estatístico, o aumento da concentração de ácido acético e a elevada umidade das silagens convencionais foram associadas ao menor consumo de matéria seca (Wright et al., 2000).

O emurchecimento em gramíneas ou leguminosas pode melhorar a qualidade da silagem, reduzindo ou eliminando perdas por efluentes, restringindo a fermentação, aumentando a pressão osmótica e melhorando a estabilidade aeróbica. Como resultado, as silagens produzem poucos ácidos orgânicos e se estabilizam com $\mathrm{pH}$ mais alto. Em silagem bem preservada, carboidratos e proteínas são pouco afetados pela fermentação, proporcionando um bom alimento para o animal, geralmente palatável, possibilitando melhores consumos (Van Soest, 1994). Entretanto, segundo a avaliação de Wright et al. (2000) a digestibilidade da matéria seca de silagens emurchecidas, em média, esteve inferior a da silagem com umidade original, resultando em correlação negativa com o consumo voluntário de matéria seca. Este fato poderia ser parcialmente explicado pela respiração das plantas durante a secagem a campo. 
Os resultados experimentais decorrentes da prática de emurchecimento, após o corte do capim-elefante, no campo, têm sido contraditórios. Além de alguns cultivares de capim-elefante apresentarem o colmo relativamente espesso e resistente, nesses trabalhos a planta foi cortada somente na altura da base, $10 \mathrm{~cm}$ do solo, e o período de emurchecimento, geralmente permitido, foi de quatro a seis horas de exposição ao sol, o que tem permitido que o teor de matéria seca da planta não aumente em mais do que três a oito unidades percentuais. No entanto, a exposição ao sol após a picagem, permitiria perdas de umidade com maior facilidade (Vilela, 1984).

Andrade et al. (1997), comparando a produção de matéria seca e o valor nutritivo do capim Coastcross $\mathrm{n}^{\circ} 1$, sob as formas de preservação como feno, silagem e silagem emurchecida, observaram que o teor de matéria seca na forma de silagem úmida e emurchecida após abertura com 28,35, 42 e 49 dias foi de 30,8; 27,9; 31,7 e 35,7\% e 49,$8 ; 48,2 ; 50,9$ e $51,2 \%$, respectivamente. Constataram que o consumo de nutrientes digestíveis totais da silagem emurchecida foi superior ao observado para o feno e para a silagem, não havendo diferenças para a digestibilidade da proteína e da FDN. A menor digestibilidade da silagem úmida quando comparada com a emurchecida pode ser explicada pela produção de calor durante a fermentação.

da Rocha et al. (2001) observaram um ganho médio diário de 83,3 g, 80,1 g e 67,8 g, para cabritos alimentados com feno, silagem emurchecida com $45 \%$ e $65 \%$ de MS respectivamente. O consumo de matéria seca e conversão alimentar também não apresentaram diferenças significativas entre os tratamentos. Segundo os autores a utilização do Tifton-85 na alimentação de cabritos em crescimento é viável, obtendo-se índices de desempenho satisfatórios.

Martins (1997) notou aumento no teor de matéria seca de forragem e redução da concentração de nitrogênio amoniacal $\left(\mathrm{N}-\mathrm{NH}_{3}\right)$, em silagem emurchecida, enquanto na úmida foi observado alto teor de NIDA (nitrogênio insolúvel em detergente ácido) o que pode ser devido ao aquecimento durante a fermentação.

A qualidade de silagem com alto teor de matéria seca ( $>30 \%)$ é dependente de dois fatores principais: o efeito termodinâmico e presença de oxigênio, em contrapartida silagens úmidas produzem calor provindo não necessariamente, de processos 
fermentativos, mas apenas da presença de radiação solar. A importante causa de perda de matéria seca por calor não envolve reação biológica, inclui a reação de Maillard (Van Soest, 1994).

Segundo Nunes \& Baptista (2001) as modificações no valor nutritivo por tal série de reações incluem decréscimo na digestibilidade protéica, redução da biodisponibilidade da lisina e de outros aminoácidos essenciais e mesmo, possivelmente, a formação de substâncias que podem ser inibidoras do crescimento microbiano, como por exemplo a lisino-alanina. Pelo menos três mecanismos são responsáveis pelo défícit assim induzido: a implicação de uma cadeia lateral de aminoácidos na reação (bloqueamento do aminoácido), formação de ligações cruzadas entre as cadeias peptídicas por condensação e uma diminuição global da digestibilidade da proteína. Logicamente, a conseqüência negativa mais óbvia da reação de Maillard nos alimentos, é a diminuição da valor nutritivo das fontes de proteína.

Segundo Minson (1990) o alto conteúdo de água não é fator limitante. Silagens frescas ou emurchecidas, na ração de bovinos, que consumiram quantidades iguais destes volumosos, verificaram que a adição de água, na silagem emurchecida, não apresentou efeito no consumo voluntário. Assim, a depressão no consumo voluntário está mais associada a mudanças na estrutura física do alimento, na quebra de proteínas, na redução de pH e na produção de ácidos orgânicos.

Em forragem fresca, o N-protéico compreende 75 a 90\% do N-total, mas durante a fermentação de silagens com alta umidade, enzimas da própria planta e de origem bacteriana causam extensa degradação protéica. $\mathrm{O}$ estímulo à produção de ácido lático em silagens de alfafa, com diferentes teores de matéria seca, devido ao uso de inoculante bacteriano, se mostrou mais efetivo para silagens com alto teor de matéria seca. Não apresentando efeito consistente no metabolismo de compostos nitrogenados durante a fermentação (Kung Júnior et al., 1994).

Durante a ensilagem, há um aumento na proporção de amônia, nitrogênio não protéico e aminoácidos livres. No emurchecimento de L. perene, a degradação de proteína bruta à amônia foi reduzida, proporcionalmente, ao teor de proteína bruta 
presente. Havendo, assim, aumento de 0,30 para 0,45 de proteína verdadeira, devido a este processamento (Minson, 1990).

O aumento do consumo de energia metabólica associado à desidratação da planta significou aumento variável na produção de leite. A correlação entre resposta energética para produção de leite e aumento do consumo de energia metabólica, indica que a perda de água resulta em uma redução de energia para produção de leite em $0,92 \mathrm{MJ} \mathrm{d}^{-1}$, mantendo o consumo de energia metabólica constante. Esta correlação também indica que o consumo de energia metabólica para animais recebendo dietas baseadas em silagem emurchecida, requer um aumento de $4,8 \mathrm{MJ} \mathrm{d}^{-1}$ para produzir quantidade equivalente de leite, às vacas alimentadas com silagem convencional (Wright et al., 2000).

Para bovinos de corte, alimentados com silagem emurchecida, a correlação linear entre aumento de consumo de energia metabólica e ganho de peso ou ganhos em carcaça, foram associados à desidratação da forragem (Wright et al., 2000).

A secagem de gramíneas produz efeito positivo no consumo de matéria seca, mas a resposta no desempenho animal, geralmente é pequena ou negativa. O resultado da avaliação de quatro silagens (silagem com inoculante, silagem acidificada com ácido fórmico, silagem emurchecida com inoculante e emurchecida e acidificada com ácido fórmico) mostrou alguns aspectos: não houve interação significativa do emurchecimento com o uso de aditivo; o tipo de aditivo não provocou efeito significativo na digestibilidade ou na utilização de energia; o emurchecimento não influenciou o consumo de energia metabólica; produção de calor; retenção de energia; sendo a digestibilidade da matéria orgânica e energia bruta significativamente menor. Assim, o consumo de energia metabólica não foi influenciado pela secagem nem pelo tipo de aditivo quando utilizado na alimentação de bovinos de corte, em crescimento (Yan et al., 1997).

Kung Júnior et al. (1994) avaliando o efeito da concentração de matéria seca (30, 40, 50, 60\% MS) com doses crescentes de inoculante bacteriano e amônia, como tratamentos, sobre os parâmetros de fermentação em silagem de alfafa, observaram que a interação entre o alto teor de matéria seca e a adição de inoculante bacteriano aumenta 
efetivamente a concentração de ácido lático devido a elevada abundância de resíduos de carboidratos solúveis. Após 21 dias da ensilagem, a silagem com $60 \%$ de matéria seca apresentou $6,09 \%$ de carboidrato solúvel comparado aos 2,19\% para silagem contendo $30 \%$ de matéria seca. Comparando as silagens com alta e baixa umidade, houve maior consumo do carboidrato solúvel original, nas silagens mais úmidas, possibilitando um decréscimo suficiente de $\mathrm{pH}$, causando inibição da fermentação microbiana (Kung Júnior et al., 1994).

Em observações preliminares (Kung Júnior et al., 1994) sugeriram que a possibilidade do prolongamento da secagem da forragem a campo reduz a população microbiana, em relação ao padrão encontrado na cultura, mas a melhor fermentação observada nas forragens emurchecidas indica a maior importância da redução de umidade de forragem, em relação à população microbiana.

\subsection{Aditivos}

Aditivos são usados na ensilagem com objetivos de melhorar a qualidade da fermentação no silo; reduzir a perda de nutrientes, pelo controle da respiração e da fermentação durante o período de armazenamento; aumentar o consumo de matéria seca e melhorar o desempenho animal (Vilela, 1984; Wilkinson, 1998). Segundo McDonald et al. (1991) os aditivos para silagem podem ser classificados em cinco categorias principais: 1) estimulantes que atuam positivamente sobre a fermentação lática. Pitt (1990a) caracteriza este grupo como estimulante ao desenvolvimento de colônia de bactérias láticas e a produção de ácidos orgânicos, que reduzem o pH; 2) inibidores que atuam inibindo parcialmente ou completamente o crescimento microbiano. Pitt (1990a) informa que os inibidores atuam tanto seletivamente, sobre processos indesejáveis tais como o crescimento aeróbico ou solubilização de proteínas, como indistintamente sobre todos os processos da fermentação; 3) inibidores da deterioração aeróbica, pois controla a deteriorização da silagem exposta ao ar; 4) nutrientes, melhora do valor nutricional da silagem e 5) os absorventes com a finalidade de reduzir a perda de nutrientes por efluentes e reduzir a incidência da poluição ambiental. 
Falhas nas legislações governamentais de diversos países tem permitido a entrada no mercado de produtos não devidamente testados. A falta de informações técnicas confiáveis sobre o produto levam o produtor à substituição de boas técnicas de manejo do silo, por aditivos, o que certamente resulta numa diminuição da qualidade do produto ensilado (Morais, 1995). Vale ressaltar, que aditivos não devem ser utilizados com o objetivo de compensar práticas inadequadas na produção e utilização de silagens (Mahanna, 1993; Muck, 1993; Pitt, 1990a). Entre os resultados experimentais, alguns são contraditórios e a recomendação do melhor aditivo dependerá; entre outros aspectos, da disponibilidade na região e das características produtivas de cada propriedade (Vilela, 1984).

\subsubsection{Inoculantes bacterianos}

Aditivos biológicos apresentam as seguintes vantagens: facilidade de uso, ser seguro, não ser corrosivo, não poluir o meio ambiente e conservar naturalmente o produto (Filya et al., 2000).

No grupo dos estimulantes, os inoculantes bacterianos são adicionados em silagem para estimular a fermentação lática, resultando em uma rápida e intensiva produção de ácido láctico acelerando a queda de $\mathrm{pH}$, melhorando a preservação e minimizando perdas (Pitt, 1990a e Weinberg et al., 1995).

Uma vez que a silagem é preservada pela fermentação lática, as bactérias homofermentativas são desejáveis, sendo que outros microrganismos causam fermentação ineficiente ou levam a silagem à deterioração (McDonald, 1991).

Stirling \& Whittenbury ${ }^{3}$, citados por McDonald (1991) mostraram em extensa revisão a ocorrência de Lactobacillus, Leuconostoc e Pediococus em plantas em crescimento, sendo inferior a $10^{2} \mathrm{~g}^{-1} \mathrm{e}$, quando presentes, na maioria das vezes, encontravam-se na bainha, na base das gramíneas, ou em material parcialmente decomposto.

\footnotetext{
${ }^{3}$ STIRLING, A.C.; WHITTENBURY, R. Journal of Applied Bacteriology, v.26, p.86-90, 1963.
} 
Foram isoladas cerca de 400 colônias e $80 \%$ destas foi representada pelos Leuconostoc, sendo as restantes originados por Lactobacillus e Pediococus. Os microrganismos são afetados pela espécie da forragem, estágio de maturidade, condições ambientais, colheita, desidratação a campo e processamento da forragem (Lin et al., 1992a,b).

Os estágios iniciais de ensilagem são críticos para o êxito da fermentação, pois a atividade enzimática da planta ainda continua e grande número de Enterobactérias podem estar fermentando açúcares solúveis. Os inoculantes são colocados para restringir esta atividade indesejável podendo conter número suficiente de bactérias homofermentativas viáveis, que possam rapidamente dominar a microflora natural (Moraes, 1995). Fenton ${ }^{4}$, citado por McDonald (1991), relatou que parece haver um aumento na contagem de bactérias láticas entre a colheita e a ensilagem do material, podendo este fato ser atribuído a inoculação realizada pela colhedora de forragem da fazenda, juntamente a multiplicação devido a liberação de conteúdo celular durante a colheita.

O mesmo autor examinando a contagem de bactérias láticas na forragem, desde a planta a campo até o segundo dia de ensilagem, observou que o número de microrganismos foi muito menor na planta a campo (10 a $\left.250 \mathrm{~g}^{-1}\right)$. No entanto, este número aumentou dez vezes imediatamente após picagem deste material. $\mathrm{O}$ número de microrganismos permaneceu estável após o início da ensilagem, onde então rapidamente começou a se multiplicar. A análise do material mostrou que a maior parte das bactérias láticas presentes, antes da colheita, originalmente era do gênero Streptococcus (80 a $100 \%$ do total). Após a colheita, o número de microrganismos aumentou de $10^{6}$ para $10^{10}$, mas a proporção de Streptococcus diminuiu para menos de $50 \%$ e os outros gêneros, especialmente Lactobacilus, tornaram-se dominantes. Novamente, concluí-se que as colhedoras constituem-se em fonte de inóculo da forragem. Inoculantes para silagem são bactérias desidratadas ou inativadas, as quais se tornam viáveis quando adicionadas à água ou à forragem (Pitt, 1990b). A maioria dos inoculantes de silagem

${ }^{4}$ FENTON, M.P. Journal of Applied Bacteriology, v.56, p. 373-379, 1987. 
consiste de culturas de bactérias láticas homofermentativas dos gêneros Lactobacillus, Streptococcus e Pediococus (Mahanna, 1993 e Pitt 1990b). Os inoculantes que contém microrganismos L. buchneri tem como finalidade a produção ácido lático e acético. Embora, o ultimo ácido seja mais fraco que o primeiro, tornando menos eficiente para garantir uma boa fermentação, este tem duas funções adicionais, melhorar a estabilidade aeróbica e inibir o crescimento de leveduras após a abertura do silo (Driehuis et al., 1999). Um dos fatores a ser considerado na adição destes inoculantes é a contagem original das bactérias láticas epifíticas na forragem colhida. Segundo McDonald (1991) as espécies mais desejáveis durante a ensilagem, estão normalmente presentes na forragem em um número 1000 vezes menor do que seus principais competidores, os fungos e Enterobactérias. Um padrão normalmente aceito pelas indústrias é de que o inoculante deve adicionar no mínimo $10^{5}$ unidades formadoras de colônia (ufc) por grama de forragem. Segundo Pitt (1990b), experimentos de campo mostraram que para um inoculante alterar a fermentação do material, a adição do inoculante deveria ser de no mínimo 0,1 variando até 10 vezes a contagem da microflora epifítica. Para alterar positivamente o desempenho animal, este nível deveria ser de 10 vezes a colonização inicial. Desta forma, para prevalecer a efetividade do inoculante seria necessário conhecer o nível de bactérias láticas epifíticas da forragem no momento da ensilagem. Rooke (1990), determinou que inoculante bacteriano deve adicionar à forragem $10^{6}$ bactérias láticas $\mathrm{g}^{-1}$ para que haja uma predominância destes microrganismos na silagem.

Weinberg \& Muck (1996) comparando diversos experimentos com linhagens de inoculantes bacterianos, diferentes condições de ensilagem, tipos de silo e combinação de inoculantes com outros tratamentos, obtiveram as mais variadas respostas, tornando difícil a comparação dos resultados. Os fatores que afetam o padrão de fermentação (e.g. presença de ar, bactérias láticas no processo de fermentação de hexoses a ácido lático e acético, etc.) e/ou qualidade final da silagem são principalmente associados a práticas de manejo, assim, se o meio não propicia condições de crescimento e multiplicação para microrganismos benéficos, mínima porção do inoculante contendo bactérias láticas poderá afetar o domínio de bactérias epifíticas ou propiciar uma possível melhora na conservação da massa ensilada. 
$\mathrm{O}$ uso de inoculantes tem demostrado ser eficiente em acelerar o processo de fermentação e reduzir a perda de nutrientes, melhorando desta forma o valor nutritivo de silagens (Mahanna, 1993). Em um levantamento de estudos publicados no período de 1990 a 1995 sobre o uso de inoculantes de gramíneas e leguminosas, Muck \& Kung (1997) concluíram que em $60 \%$ dos casos houve redução do pH e mudança na fermentação em direção ao aumento na produção de ácido lático. Além disso, os níveis de amônia foram reduzidos com o mesmo grau de intensidade, indicando maior preservação da proteína nas silagens inoculadas (Muck \& Kung, 1997). Além de alterar a fermentação, o uso de inoculantes pode condicionar o desempenho do animal. Em um levantamento de trabalhos publicados no período de 1985 a 1992 sobre a influência dos inoculantes na fermentação de forragens, valor nutritivo da silagem e desempenho do animal, concluiu-se que este último fator sofreu menor impacto (Muck, 1993). O consumo e o ganho médio diário em bovinos e ovinos aumentaram significativamente em $25 \%$ dos experimentos. A produção de leite e eficiência alimentar foram melhoradas em menos de $50 \%$ dos estudos. Quando foram observados efeitos significativos, o consumo de matéria seca, ganho médio diário, produção de leite e eficiência alimentar foram amplificados em 11, 11,5 e 9\%, respectivamente (Muck, 1993). Os benefícios sobre o desempenho foram explicados principalmente por aumentos de digestibilidade (Muck, 1993).

Kung Júnior \& Ranjit (s.d.) avaliando o efeito do Lactobacillus buchneri em silagem de cevada, obtiveram as seguintes tendências após 69 dias da ensilagem: aplicado exclusivo ou associado com enzima mostrou aumento linear na concentração de ácido acético assim como uma concentração mais acentuada de ácido propiônico e etanol quando comparado com a silagem controle; nos tratamentos com o inoculante ou contendo ácidos fracos a queda no $\mathrm{pH}$ se deve à alta concentração de ácido lático em comparação com a silagem controle; a concentração de $5 \times 10^{5}$ ufc $\mathrm{g}^{-1}$ melhorou a estabilidade aeróbica da silagem, e manteve baixa a contagem de fungos após a abertura do silo, por um longo período.

A aplicação do inoculante bacteriano em silagem de sorgo apresentou efeito variável sobre a qualidade nutricional e parâmetros de fermentação, considerando-se a 
média dos resultados em três períodos de coleta, onde alguns aspectos benéficos foram observados, como menor concentração de cinzas (3,55 vs. 3,96\% da MS) e nitrogênio amoniacal ( 0,07 vs. $0,08 \%$ da MS), entretanto, a silagem apresentou menor teor de ácido lático $(4,11$ e 4,78\% da MS) que o controle. Para os parâmetros nutricionais mostrou níveis elevados de FDN (41,28 vs. 39,14\% da MS) e FDA (24,89 vs. 22,53\% da MS), evidenciando maior perda de conteúdo solúvel, apesar de não ter havido diferença para proteína bruta (7,93 vs. $7,99 \%$ da MS) e energia bruta (4,46 vs. 4,44 $\mathrm{kcal} \mathrm{g}^{-1}$ da MS) em relação ao controle (Pedroso et al., 2000).

O inoculante bacteriano não alterou a composição bromatológica de plantas de milho ensilados com diferentes proporções de espigas: $100 \%, 75 \%, 50 \%, 25 \%$ e $0 \%$ em termos de MS, MO, FDA, NDT e DIVMO, mas apresentou efeito positivo no teor de $\mathrm{PB}$, possivelmente devido à menor proteólise, pois houve queda no teor de $\mathrm{N}-\mathrm{NH}_{3}$, principalmente para o nível de $100 \%$ de espiga em relação a $0 \%$ e $25 \%$. (da Silva et al., 1997).

As estirpes de bactérias láticas adicionadas às silagens de milho com alto e baixo teor de matéria seca, não apresentaram efeito no processo de fermentação, e o benefício observado na digestibilidade da fibra in vivo, utilizando carneiros, não repercutiu em melhor desempenho, digestibilidade in vivo e in situ, bem como não houve alteração na taxa de passagem para novilhos da raça Nelore (Morais, 1995).

Silagens inoculadas com aditivo proporcionaram aumento no teor de matéria seca, carboidratos solúveis, $\mathrm{N}$-amoniacal e etanol em relação as não inoculadas, promoveram redução significativa na capacidade tampão e conteúdo de cinzas. Não ocorreram diferenças para $\mathrm{pH}$, proteína bruta e FDA, entretanto foram observados aumentos na concentração de energia bruta e redução na produção de ácido lático e propiônico, bem como do $\mathrm{AGV}$ total. A digestibilidade in vitro da matéria orgânica nas silagens oferecidas a ovinos não diferiram estatisticamente (Agnew \& Carson, 2000).

O tratamento com inoculantes melhorou a fermentação da silagem no intervalo de 56 a 227 dias de estocagem, mas este efeito não foi observado no intervalo de 252 a 324 dias pós ensilagem. Entretando, apesar da aparente ausência na melhora da fermentação das silagens quando foi fornecida como alimento, o tratamento contendo inoculante, 
aumentou a digestibilidade, em particular a fração fibra, de silagens utilizadas exclusivas ou acompanhadas de suplementação concentrada. O melhor desempenho do animal, devido ao tratamento com inoculante, possivelmente advém do aumento do consumo de matéria seca e, consequentemente, do aumento da energia metabolizável, sugerindo que houve aumento na digestibilidade da fibra (Keady \& Steen, 1995).

\subsubsection{Enzimas}

A possibilidade de síntese e secreção de uma enzima complexa como a 1-4 celulase por microrganismos do rúmen, permite a hidrólise da parede celular, sendo entretanto, baixa a conversão alimentar de alimentos fibrosos. Somente 10 a $35 \%$ da energia consumida é utilizada pelo animal sendo que 20 a $70 \%$ da celulose, contida no alimento, não pode ser digerida. Os principais fatores que regulam a degradação da fibra no rúmen são: estrutura e composição da planta que pode interferir ou mesmo bloquear o acesso dos microrganismos ruminais aos nutrientes; a densidade populacional de microrganismos que utilizam os componentes da parede celular como substrato; fatores microbianos que controlam a ação enzimática, e o fator animal que pode melhorar a disponibilidade de nutrientes através da mastigação, salivação e cinética de digestão (Vargas \& Kolver, 1997).

As enzimas são aditivos que pertencem ao grupo dos estimulantes e as classes mais comum, em produtos comerciais, são as celulases e hemicelulases (Muck \& Kung, 1997). Apesar da considerável diversidade de enzimas, o número de famílias (onze) é restrito. Dentro de cada família, os dados disponíveis sugerem que várias enzimas apresentam um mesmo padrão tridimensional, os mesmos resíduos catalíticos e o mesmo mecanismo de ação. Enzimas pertencentes a diferentes famílias são encontradas no mesmo organismo, o que sugere que a grande variedade de domínios catalíticos das celulases e hemicelulases derivam de um número limitado de padrões básicos, e que as diferentes especificidades e modos de ação destas enzimas poderão ser conseqüência de alterações mínimas da sua estrutura tridimensional, em vez de uma total alteração da conformação protéica (Ferreira et al., 1999). 
Tradicionalmente, muitos pesquisadores questionam a eficiência de utilização do complexo enzimático sobre o alimento, devido à potencialidade de degradação da fibra, por microrganismos do rúmen. Outros acreditam que a inclusão de enzimas em silagens aumentem a disponibilidade de substrato para bactérias láticas para produção de ácido lático, pela degradação de carboidratos complexos em carboidratos solúveis e também contribuem para reduzir o conteúdo de fibra da forragem (Mahanna, 1993 e Muck \& Kung, 1997).

Três tipos de enzimas participam na degradação da celulose: endoglucanase, que de uma forma aleatória clivam as ligações glicosídicas internas deste polímero; exoglicanas, também referidas como celobiohidrolases que, seqüencialmente, removem dímeros de celobiose de uma das terminações da celulose; e as $\beta$-glucosidases que são responsáveis pela hidrólise da celobiose. Enquanto as endoglucanas agem somente nas regiões não cristalinas da celulose (também designada de regiões amorfas), as celobiohidrolases atuam sobre as terminações não redutoras da celulose, independente da forma física apresentada por este polímero. A degradação das hemiceluloses é mais complexa, já que a cadeia polimérica se encontra ligada a numerosas cadeias laterais (Fontes et al., 1996).

Em estudos conduzidos entre 1990 e 1995 sobre os efeitos de enzimas na composição e fermentação de silagens, observou-se que em $90 \%$ dos casos esses produtos foram efetivos na redução do conteúdo de fibra de silagens de gramíneas. Entretanto, a fermentação, avaliada através do $\mathrm{pH}$, concentração de amônia e da relação ácido lático:ácido acético foi favorecida em menos de 50\% dos casos (Muck \& Muck, 1997). Quanto à produção do animal, a partir de resultados apresentados na literatura, concluiu-se que o uso de enzimas apresentou efeito positivo sobre o consumo de matéria seca, ganho de peso, produção de leite e eficiência alimentar em 21, 40, 33 e 27\% dos casos, respectivamente (Muck \& Muck, 1997; Nussio et al., 1997).

O método de aplicação de enzimas exógenas na dieta de vacas em lactação é fator crucial para sua ação. Sua aplicação nos ingredientes concentrados da dieta, pode ser traduzida pelo efeito positivo na produção de leite, como pelo aumento da digestibilidade de nutrientes, no trato digestivo total. Entretanto, a aplicação de enzimas, 
em ração de mistura total, provocou melhora na digestibilidade, mas não houve efeito na produção de leite (Yang et al., 2000). Com relação à concentração de enzimas fibrolíticas exógenas, altas dosagens não proporcionaram efeito na digestibilidade total de nutrientes, em cordeiros. Enzimas geralmente causam aumento da digestão de nutrientes para vacas, devido ao baixo potencial de degradação ruminal, quando comparada com a digestibilidade observada em ovinos ou à digestibilidade in vitro. Com isto, acredita-se que os ovinos não constituem um modelo adequado para se extrapolar dados da ação enzimática para bovinos (Yang et al., 2000). Segundo Gilbert \& Hazlewood $^{5}$, citado por Fontes et al. (1996), as condições para a degradação da celulose e hemicelulose in vivo podem implicar na especialização das isoenzimas a condições para a reação enzimática muito diferenciadas, até agora impossíveis de serem simuladas ou observadas nos ensaios in vitro.

Evidências indicam melhores ganhos de peso e produção de leite para ruminantes alimentados com forragens e grãos tratados por enzimas fibrolíticas. Alguns dados sugerem que o tratamento com altas doses enzimáticas pode ser prejudicial, e a combinação de várias enzimas pode melhorar a eficiência de outras, por sinergismo. $\mathrm{O}$ aumento na produção de leite pode ocorrer sem mudanças aparentes na ingestão de matéria seca ou na fração fibrosa do alimento. Nesse estudo, silagem de milho e feno de alfafa tratados com enzimas melhoraram a produção de leite sem causar mudanças na composição da forragem (Kung Júnior et at., 2000).

Lewis et al. (1999) mostraram efeito benéfico na aplicação de enzimas diretamente sobre os ingredientes de dietas de vacas em lactação. Foram observados aumentos significativos para a produção, proteína e gordura do leite. Em um segundo experimento realizado pelos mesmos pesquisadores, detectou-se melhora na produção de leite corrigida. A melhor resposta de desempenho em lactação foi obtida com $2,5 \mathrm{~mL} \mathrm{~kg}^{-1}$ de matéria seca de forragem indicando a importância em se determinar, com exatidão, a quantidade de enzima para se obter a resposta desejada.

\footnotetext{
${ }^{5}$ GILBERT, H.J.; HAZLEWOOD, G.P. Bacterial cellulases and xylanases. Journal Gen. Microbiology, v139, p.187-194, 1993.
} 
O efeito adaptativo da população microbiana pode ser resultado do consumo prolongando do alimento sob a ação da enzima, que condiciona a maior digestão da fibra e alteração da dinâmica da população microbiana (Wallace et al., 2001). A aplicação direta de enzimas sobre feno de gramínea geralmente promove benefícios sobre a digestão de nutrientes. Entretanto, a razão da menor eficiência enzimática através da infusão, no rúmen, não é conhecida, embora por hipótese haja insuficiência de contato entre a enzima e a partícula (Lewis et al., 1996).

Foi proposto um mecanismo de degradação da celulose em aerobiose, que se inicia pela ação das endoglucanases sobre as regiões amorfas deste polissacarídeo. Este processo resulta na criação de novas terminações não redutoras, no polímero, que serve de substrato para a ação das celobiohidrolases. Estas enzimas atuam na degradação da celulose, independentemente, da forma física do polissacarídeo. Este fato caracteriza a ação sinergística entre endoglucanases e celobiohidrolases. Finalmente, as $\beta$ glucosidases presentes no citoplasma das células microbianas degradam as moléculas de celobiose, prevenindo o seu acúmulo, com conseqüente, das celobiohidrolases (Béguin $\&$ Aubert $^{6}$ e Coughlan ${ }^{7}$, citados por Fontes et al., 1996).

O ambiente ruminal é muito competitivo sujeitando as enzimas, individualmente, a condições físico-químicas que podem comprometer sua viabilidade. Por outro lado, a agregação enzimática poderá ser um meio eficiente de manter estes biocatalizadores associados aos microrganismos, tornando os produtos de hidrólise da parede celular vegetal, mais facilmente utilizáveis pelas células microbianas (Fontes et al., 1996).

O efeito pós-ruminal não pode ser ignorado uma vez que as enzimas são pouco suscetíveis a inativação no duodeno e intestino delgado. Como exemplo, pode ser citado o aumento da atividade da xilanase, em comparação com as enzimas microbianas do rúmen (Wallace et al., 2001).

Considerando que a baixa concentração de carboidratos solúveis representa um fator limitante para o desenvolvimento de bactérias homoláticas, presentes nos

\footnotetext{
${ }^{6}$ BÉGUIN, P.; AUBERT, J-.P. The biological degradation of cellulose. FEMS Microbiology Review, v.13, p.25-58, 1994.

${ }^{7}$ COUGHLAN, M.P. Animal Feed Science Technology, v.32, p.77-86, 1991.
} 
inoculantes para silagens, pode-se especular que a associação de inoculantes e enzimas deveria estimular a fermentação de forragens pobres em substratos prontamente fermentescíveis (gramíneas tropicais). O uso de inoculante e enzima, isoladamente ou associados, na silagem do Tifton 85 e Coastal Bermuda foi estudado por Mandebvu et al. (1997). Estes autores concluíram que o desaparecimento da matéria seca in vitro e in situ e a concentração de fibra não foram afetados pelos tratamentos. Em avaliação similar, a digestibilidade da fibra foi significativamente aumentada pelo uso de enzimas durante a ensilagem (Mandebvu et al., 1998).

A utilização de enzimas, se mostra benéfica para ensilagem de culturas com baixa concentração de açúcares solúveis como no caso de gramíneas e leguminosas com baixo teor de matéria seca, devido a liberação de açúcares provenientes da hidrólise da parede celular, que promovem substrato adicional para produção de ácido lático, pelas bactérias. A elevada produção de ácido lático diminui o $\mathrm{pH}$ para um valor próximo de quatro, restringindo a atividade proteolítica.

Nadeau et al. (2000) avaliando a ação isolada ou associada de enzimas com outros aditivos em silagem de alfafa e grama de pomar, obteve as seguintes respostas: a enzima celulase na dose $10 \mathrm{~mL} \mathrm{~kg}^{-1}$ pode ser aplicada exclusiva ou combinada com pectinase, inoculante ou ácido fórmico; a ação isolada da celulase possibilita diminuição no teor de FDN; melhora nas características de fermentação de silagem com a aplicação $2 \mathrm{~mL} \mathrm{~kg}^{-1}$ de celulase combinada com inoculante microbiano. Contudo, o decréscimo de FDN e aumento na concentração de açúcar solúvel não melhoraram a digestibilidade da fibra de silagens tratadas com celulase. Ensaios similares utilizando plantas em diferentes graus de maturidade sugerem que pode haver redução da hidrólise enzimática na parede celular, principalmente pela ação da lignina que diminui a área de superfície acessível às enzimas celulolíticas.

A quantidade de enzimas ativas aplicadas atualmente nos alimentos, se constitui em um fator importante na determinação da eficiência do tratamento. A dificuldade em se mensurar a eficiência de distribuição de pequenas quantidades de líquidos ou sólidos, nos alimentos, reflete a grande proporção da razão líquidos:sólidos usados em experimentos: $0,05 \mathrm{~mL}$ de enzimas diluída para cada 0,5 gramas de alimento, 
equivalente a 100 litros por tonelada; diluição muito superior àquela recomendada para aplicação comercial de 1,5 ou 2,0 $\mathrm{L}$ tonelada ${ }^{-1}$. Além disso, há maior facilidade em se misturar pequena quantidade de enzimas aos alimentos, que grandes quantidades usadas em fazendas com baixo nível tecnológico (Wallace \& Hartnell, 2001). A distribuição eficiente do aditivo enzimático é um ponto crítico, para sua eficácia, que por sua vez é dependente do seu modo de ação. A eficiência dos aditivos enzimáticos é dependente do manejo pré-alimentar, havendo a necessidade de uma distribuição homogênea no alimento antes do consumo que pode ser crucial para a efetividade do tratamento (Wallace \& Hartnell, 2001).

\subsection{Vedação do silo}

De acordo com o manual de revestimento de fardos Trioplast $\mathrm{AB}$, durante os anos de 1970, as primeiras embalagens de silagem em polietileno foram usadas no Reino Unido, gerando resultados variáveis, principalmente, devido à quantidade excessiva de ar remanescente na embalagem, e a dificuldade em se obter eficiente vedação do sistema. No decorrer dos anos, os equipamentos utilizados no revestimento de fardos foram sendo aperfeiçoados, tornando o sistema totalmente automatizado. A popularização desta técnica se deu pelas seguintes vantagens: silagem revestida pode ser facilmente comercializada com base no seu valor nutritivo, pois os fardos podem ser embalados gradativamente associando parâmetros quantitativos e qualitativos da forragem; o sistema requer menores investimentos fixos e os custos podem ser limitados usando-se a terceirização ou parceria na utilização dos equipamentos; cada fardo é uma unidade vedada, geralmente muito mais desidratada do que a silagem à granel, onde a probabilidade de efluentes é extremamente pequena e há facilidade de armazenamento e transporte.

Segundo Chamberlain \& Wilkinson (2000), a silagem revestida por lona apresenta vantagens quanto a qualidade nutricional da silagem uma vez que a melhor vedação leva a um padrão de fermentação mais restrito, onde o aumento do consumo se deve à menor acidez da silagem. 
De acordo com as recomendações da empresa Trioplast, o emurchecimento é importante para se atingir uma adequada fermentação e densidade do fardo, sendo os melhores resultados obtidos com uma concentração igual ou superior a 45\% MS, e não havendo necessidade de aditivos para concentração acima de 40\%. O emurchecimento utilizado de forma adequada poderia ajudar a aumentar a densidade do fardo uma vez que dificilmente a ação da enfardadeira poderia desidratar as células vegetais inteiramente, durante o curto período envolvido, na compressão da silagem.

\subsection{Fatores que interferem na resposta animal}

\subsubsection{Consumo de matéria seca}

O consumo voluntário diz respeito à ingestão ad libitum de um único alimento e sua determinação é influenciada por fatores como variação animal, palatabilidade e capacidade de seleção. Sem dúvida, o maior determinante no consumo é a qualidade do alimento ou dieta, mas o consumo voluntário pode variar também em função do animal, sua demanda energética e mesmo sua individualidade (Mattos, 1992).

O máximo consumo de uma forragem pelo ruminante depende das taxas de desaparecimento de celulose e hemicelulose, no rúmen. Estas taxas dependem de vários fatores que interferem na atividade da flora microbiana do rúmen, como: estágio de maturação das forrageiras; ausência de nutrientes para a microflora como nitrogênio ou minerais e a presença, de agentes bacteriostáticos (Thiago, 1984). Em forragens de baixa taxa inicial de ingestão, a distensão ruminal parece ser o fator mais importante limitando o consumo (ocorrendo antes que as necessidades energéticas do animal sejam atendidas), mas com forragens de alta taxa de digestão (e.g. leguminosas ou silagem) o consumo parece estar mais relacionado com a liberação de nutrientes no rúmen, ao invés do simples efeito físico de distensão ruminal (Thiago \& Gill, 1990).

O consumo de silagem, com freqüência, tende a ser abaixo do esperado quando se compara com feno com similar conteúdo de FDN e digestibilidade. O menor consumo é provavelmente resultado do desbalanço metabólico induzindo perdas na fermentação 
(Van Soest, 1994). Este resultado geralmente é caracterizado por mudanças na fração dos carboidratos solúveis e proteína. Em silagens, carboidratos solúveis e proteínas são transformados em ácidos orgânicos e nitrogênio não protéico, respectivamente.

O volume ruminal limita o consumo de dietas com alta proporção de forragens. Entretanto, este volume não traduz a completa ação ruminal, porque sólidos e líquidos ainda que misturados no rúmen continuamente, possuem taxas diferentes de passagem e desaparecimento. Ambos, volume e taxa de passagem devem ser combinados para determinar a quantidade de material que pode ser ingerido diariamente (Church, 1993).

A quantidade de silagem ingerida por bovinos aumenta quando diminui a incidência de produtos de fermentação secundária. Portanto, se eleva com o aumento do teor de matéria seca. Para alcançar o máximo consumo de silagem a sua concentração de matéria seca deve estar próxima de 35\%. Ao contrário, os ovinos são menos sensíveis ao teor de MS sendo o tamanho de partícula, o principal elemento que regula o consumo de silagem. Em média, a ingestão de silagem é 45\% maior para um tamanho de partícula reduzido (1 a $2 \mathrm{~cm})$, quando comparada a um tamanho de corte superior $(\sim 10 \mathrm{~cm})$. Para os bovinos essa diferença oscila de $15 \%$ a 20\% (Minson, 1990).

Segundo o NRC (2001), o consumo de matéria seca correlaciona-se negativamente com o teor de umidade do alimento, ocorrendo decréscimo de $2 \%$ no consumo para cada $1 \%$ de umidade contida no alimento. Há redução no consumo de matéria seca em forragens conservadas pelo processo de silagem, com alto teor de umidade, em decorrência da fermentação. Em silagens bem conservadas o consumo de matéria seca tende a ser máximo quando o teor de umidade está abaixo de 60 a 65\%. Entretanto, torna-se importante lembrar que a ensilagem de forragens com teor de umidade inferior a $55-60 \%$ requer cuidados especiais, podendo afetar seriamente a digestibilidade (Peixoto et al., 1988).

Em rações balanceadas contendo alimentos fermentados (silagem), a ingestão aumenta com o aumento do teor de matéria seca da ração total até cerca de $45 \%$ de matéria seca, aproximadamente (Boin, s.d.). 


\subsubsection{Parâmetros microbiológicos do rúmen}

A ecologia da fermentação, no silo, é diferente da fermentação ruminal pois um reduzido grupo de microrganismos tende a se desenvolver sobre o substrato. $\mathrm{O}$ ácido lático produzido por microrganismos na silagem realiza rápida diminuição do $\mathrm{pH}$, este processo é pouco eficiente do ponto de vista energético, visto que a concentração final de ácido lático, no rúmen, tem importante efeito no balanço ecológico. Tanto a fermentação no silo como a ruminal se desenvolvem na ausência de ar, entretanto a utilização de celulose como substrato só ocorre no rúmen, e resulta na síntese de proteína microbiana, fonte de proteína para o animal hospedeiro (Van Soest, 1994).

Nos ruminantes, a maior parte da celulose é digerida no rúmen, contudo, a capacidade das enzimas em digerir a celulose envolve somente a habilidade para romper as ligações $\beta-1,4$. Este processo depende também da ação cooperativa de diversos microorganismos, já que nenhum organismo isoladamente produz o conjunto de enzimas responsáveis pela degradação dos componentes celulolíticos e hemicelulolíticos, da parede celular. Entende-se que a degradação eficiente da celulose e hemicelulose depende da ação sinergística do complexo de todas as enzimas requeridas para a hidrólise, de ambos os substratos. Aos sistemas celulolíticos estão de fato sempre associados sistemas hemicelulolíticos, particularmente xilonolíticos, devido às interações que se estabelecem na parede celular entre a celulose e as hemiceluloses. Assim, através desta rede complexa, uma parte substancial da hemicelulose escapa à degradação ruminal, sendo fermentada no intestino grosso. Existem poucas evidências para explicar o motivo pelo qual grupos arabinose são timidamente digeridos no rúmen (Ferreira et al.,1999).

O pH ruminal é uma variável ecológica que pode influenciar profundamente a população microbiana. Estudos mostram que a eficiência de crescimento e a predominância de bactérias, no rúmen, varia com o $\mathrm{pH}$. Bactérias celulolíticas e metanogênicas são severamente afetadas por um $\mathrm{pH}$ abaixo de seis. Os protozoários são também afetados pelo abaixamento de $\mathrm{pH}(5,5)$ ou excesso de concentrado na dieta (Church, 1993). 
$\mathrm{O}$ decréscimo do $\mathrm{pH}$, até níveis críticos para a população fibrolítica, afeta as atividades polissacaridase microbiana, e sua capacidade de adesão. Este distúrbio pode ocorrer em caso de forragens com alto conteúdo em açúcares solúveis e parede celular facilmente degradável, assim como a incorporação de concentrado energético na dieta (Nogueira Filho, 2001).

Dehority \& Tirabasso (2001) demostraram que em animais recebendo alimentação volumosa, uma única vez ou várias vezes ao dia, houve pequeno efeito na concentração de bactérias e fungos no rúmen. Em contraste, o maior número de refeições diminuiu o $\mathrm{pH}$ e aumentou o teor de matéria seca, no rúmen, não sendo observado efeito consistente da freqüência de alimentação sobre o volume ruminal ou na reciclagem do fluido ruminal.

\subsubsection{Aspectos da cinética ruminal}

O alimento consumido pode sofrer transformações físicas e metabólicas, até ser absorvido pelo animal. Características do sistema digestivo são atribuídas a uma dinâmica interativa com o alimento que resulta em crescimento e manutenção do ecossistema ruminal promovendo a chegada de nutrientes que suprirão as exigências nutricionais do ruminante. A maior parte dos nutrientes, potencialmente não degradados na dieta, é originado na fração FDN, indicado como uma medida para determinar o tempo de resistência do alimento à degradação, do mesmo modo que seus resíduos de digestão produzem efeitos de resistência física, no rúmen, regulando a ação do "turn over" de massa. Interpretações sugerem que o ecossistema ruminal pode ser considerado contínuo, cujo tempo de resistência, em média, pode ser regulado pelo nível de consumo e composição da dieta promovendo, assim, uma melhor utilização dos nutrientes pelos tecidos (Ellis et al., 2000).

Eventos físicos relacionados com a redução do tamanho de partícula ou redução da fibra indigestível no rúmen são importantes reguladores do consumo de forragem, e consequentemente, da produtividade de ruminantes que se alimentam de forragens. A redução do tamanho de partícula é um processo limitado pela digestibilidade da fibra, no 
rúmen. Acidose e alta pressão osmótica podem inibir a atividade de ruminação, e esta exclusivamente não é capaz de manter a produção de ácidos graxos voláteis no seu nível normal. A redução do tamanho de partícula é necessária para a saída da forragem, no rúmen, e depende da ação de microrganismos e da fratura física de partículas pelos movimentos do rúmen. $\mathrm{O}$ tamanho específico da partícula que ultrapassa o rúmen é normalmente crítico, pois atua como um importante controlador do apetite, para ruminantes (Welch, 1982).

Os efeitos físicos da hidrólise de carboidratos estruturais determinam o fluxo de nutrientes potencialmente hidrolisáveis, como carboidratos e proteína bruta. Assim, o fluxo ruminal de aminoácidos e energia atuam sobre o nível de consumo. Biologicamente, o nível de consumo sugere interação com as exigências de aminoácidos, em contraste com os efeitos físicos, capacidade metabólica ou balanço incorreto de nutrientes que podem ser metabolizados. Resultados de pesquisa sugerem que o consumo de alimentos é regulado, provavelmente, pela exigência em energia e aminoácidos consumidos no metabolismo aeróbico, do ruminante. A maior incerteza envolvida na predição do nível de consumo, em ruminantes, reside na predição da produção de nutrientes metabolizáveis providos pelo sistema (Ellis et al., 2000).

O tempo de trânsito pós-ruminal é, em média, semelhante ao tempo de resistência na fase de aderência e colonização microbiana no rúmen e, este conjunto, não é afetado pelo nível de FDN indigestível, apresentando-se constante em torno de 10 horas. Em contraste, o tempo de resistência média, tem ação na reciclagem apresentando relação positiva e linear com a concentração de fibra indigestível da dieta (Ellis et al., 2000).

\subsubsection{Fibra}

Fibra pode ser considerada como uma unidade biológica, não uma entidade química. As características e valor nutritivo dos alimentos e forragens são determinados por dois fatores: a proporção da parede celular lignificada e a quantidade de conteúdo celular (Van Soest, 1994). 
O consumo reduzido de forragem é geralmente inferior ao potencial previsto, especialmente devido à baixa qualidade da forragem. Porém, existem dúvidas sobre a afirmação de que este consumo reduzido é devido ao volume da parede celular da planta. Contudo, a real possibilidade da contribuição do efeito da parede celular seria devido à uma interação de massa, extensão da parede ruminal e densidade energética que pode apresentar ação independente do conteúdo da parede celular (Minson, 1990).

Neste contexto, o NRC (1989) recomenda o uso de 21\% de FDA e 28\% de FDN na dieta de vacas leiteiras, no início da lactação (primeiras três semanas). Porém, vacas com elevadas produções de leite necessitam de uma concentração ainda mais reduzida, na ordem de $19 \%$ de FDA e de $25 \%$ de FDN, de forma a aumentar a concentração da energia metabolizável da dieta, sem causar danos à produção atual e futura, bem como minimizar a possibilidade de futuros distúrbios metabólicos. Com o avanço da lactação, os níveis de fibra deverão ser aumentados, a fim de buscar a manutenção do teor de gordura do leite e diminuição da ingestão de energia, devido as exigências nutricionais dos animais serem decrescentes nesta fase. Esta recomendação, ainda enfoca que pelo menos $75 \%$ do FDN seja oriundo de forragem.

No entanto, dietas formuladas com baixa contribuição de FDN proveniente de forragens e alta participação de FDN de concentrados, podem ser adequadamente balanceadas em situações onde há baixa disponibilidade de forragem ou quando as forragens são de baixo valor nutritivo, ou ainda quando se objetiva maximizar o número de animais por unidade de forragem produzida (Pereira \& Armentano, 1997).

Fisicamente, o efeito da fração fibra no alimento é de estimular a atividade de mastigação. Esta, altera os estímulos de secreção de saliva, cujos sais de bicarbonatos e fosfatos servem para neutralizar ácidos produzidos na fermentação ruminal. O balanço entre a produção de ácidos oriundos da fermentação e a secreção de tampões é o maior determinante do $\mathrm{pH}$ ruminal. A queda no $\mathrm{pH}$ diminui o consumo de matéria seca, a digestibilidade da fibra, produção microbiana, decréscimo na produção de leite e finalmente eleva o custo de produção. A produção de ácidos, no rúmen, deve ser atribuída primeiramente à fermentação de carboidratos, perfazendo $65 \%$ da matéria seca 
da dieta de vacas, e sua degradabilidade ruminal pode ser variável para diferentes dietas (Allen, 1997).

A densidade da parede celular está relacionada com a lignificação. Isto conduz a um potencial contraditório da teoria do enchimento desde que a parede celular das plantas não tenha densidade uniforme e a parede celular madura lignificada é mais densa do que as imaturas. Gramíneas tropicais $\mathrm{C}_{4}$ tendem a ter alto conteúdo de FDN e variação considerável em lignificação e, possivelmente, na densidade da parede celular. Ambas, densidade da forragem e densidade da parede celular, tem pouca correlação com consumo voluntário $(\mathrm{r}=0,3$ e 0,4$)$ e com o conteúdo da parede celular $(\mathrm{r}=0,76)$ (Minson, 1990).

No ataque microbiano da parede celular, particular importância tem sido dada à associação física entre as células bacterianas e vegetais (fenômeno de aderência). Vários tipos de bactérias aderem às superfícies da planta ingerida, invadem os estômatos, e proliferam-se, atingindo os tecidos internos. Esta fragmentação facilita e torna mais rápido o acesso às áreas intercelulares, sendo um requisito para as relações simbióticas entre microrganismos. A ruptura das paredes celulares parece variar ligeiramente com a família vegetal, não havendo a necessidade de adesão das bactérias celulolíticas para efetuar a digestão. $\mathrm{O}$ estudo microscópio da parede celular permitiu constatar que existem dois modos principais de atuação: formação de cavidades, localizadas principalmente na parede celular secundária e erosão das superfícies (Ferreira et al., 1999).

A extensão da digestão da parede celular é o resultado da interação entre a taxa de digestão e a taxa de passagem, não assumindo um valor estático. A fase líquida e, particularmente, a taxa de renovação desta fase são correlacionadas positivamente com o consumo. Assim, conforme aumenta o consumo, a digesta que deixa o rúmen irá conter partículas de nutrientes nos primeiros estágios da digestão, resultando em menor digestibilidade da matéria seca. Considerando que a taxa de degradação do carboidrato estrutural e a taxa de passagem são da mesma magnitude, e que o consumo elevado deprime a digestibilidade do carboidrato estrutural, mais intensamente que o carboidrato 
não estrutural, é natural aceitar que existe compensação no sistema, traduzida por maior ingestão de energia bruta e digestão intestinal (Vargas \& Kolver, 1997).

A estrutura da fibra longa é o maior fator limitante no consumo voluntário. A baixa ingestão voluntária pode ser em parte causada pela grande resistência à quebra no tamanho de partículas e ao seu tempo de retenção no rúmen (Minson, 1990). O tamanho de partícula influencia o FDN efetivo incluindo o grau de lignificação da fibra, o grau de hidratação e sua capacidade tamponante (Vargas \& Kolver, 1997).

\subsubsection{Proteína}

A proteína da silagem pode ser degradada em aminoácidos e ser utilizada por microrganismos, no rúmen. A hidrólise não é a melhor forma de suprir aminoácidos para síntese de proteína microbiana, uma vez que aminoácidos em excesso saem do rúmen e são absorvidos no intestino delgado. Aminoácidos em conjunto com formas de nitrogênio orgânico e solúvel, além do nitrogênio solúvel presente na forragem e saliva, podem ser convertidos em amônia e proteína microbiana. A amônia pode ser usada na produção de proteína microbiana, no rúmen, mas há um limite na quantidade de amônia a ser utilizada por essa via. O excesso de amônia é absorvido no rúmen e intestino e convertido à uréia, no fígado. Parte desta uréia pode ser reciclada, no rúmen, via saliva e a remanescente, excretada na urina (Minson, 1990). O excesso de amônia, no rúmen, pode inibir o consumo de alimentos, mas a situação pode ser amenizada com a adequada suplementação de carboidratos. Em outras circunstâncias a infusão de aminoácidos, via cânula duodenal, aumenta o consumo de silagem. Observações consistentes levam à hipótese de que a fermentação, no silo, consome a maior parte do carboidrato solúvel, levando à baixa produção e utilização do alimento pelas bactérias microbianas, no rúmen, em conjunto com o aumento do conteúdo de nitrogênio não protéico (NNP). A presença de carboidrato solúvel proveniente da dieta estimula a produção de proteína microbiana e utilização de NNP. Proteínas e aminoácidos provenientes da silagem, dificilmente atendem à exigência de nitrogênio, do animal (Van Soest, 1994). 
Rook \& Gill (1990), não observaram evidência definitiva na literatura de que a fração amônia seja um fator limitante de consumo voluntário e consideram seu efeito indireto ou associado a outras causas. Estes autores suportam a hipótese de que os ácidos graxos voláteis produzem um maior efeito supressor, sendo o ácido butírico geralmente o melhor estimador da qualidade da silagem.

A maior parte da proteína bruta de forragens frescas e silagens é degradada no rúmen, somente $25 \%$ em média, passa sem mudanças para o intestino delgado (Minson, 1990).

Uma vez que a silagem é ingerida pelo ruminante, sua extensão de degradação dependerá da atividade dos microrganismos ruminais e do tempo que a forragem ali permanece. As proteínas solúveis são inicialmente degradadas por bactérias e, posteriormente, os protozoários darão seqüência ao processo de degradação desta fração (Minson, 1990). 


\section{MATERIAL E MÉTODOS}

\subsection{Local do experimento}

O trabalho foi realizado no Departamento de Produção Animal, Setor de Ruminantes, da Escola Superior de Agricultura "Luiz de Queiroz" (ESALQ-USP), no município de Piracicaba - SP a $22^{\circ} 45^{\prime}$ de latitude Sul, $47^{\circ} 38^{\prime}$ de longitude Oeste e a uma altitude de 537 metros. As análises bromatológicas foram conduzidas no Laboratório de Bromatologia, pertencente ao mesmo Departamento.

\subsubsection{Condução agronômica}

A cultura forrageira utilizada para confecção da silagem foi proveniente de uma gleba de capim Tifton 85 (Cynodon dactylon spp.) destinada a produção de feno, estabelecida desde 1996, na Fazenda Água Comprida (Água Comprida/MG), localizada sob as coordenadas $19^{\circ} 56^{\prime} 45^{\prime \prime}$ sul de latitude e $48^{\circ} 02^{\prime} 15^{\prime \prime}$ de longitude oeste. $\mathrm{Na}$ referida base física, o solo apresentava textura argilosa, classificado como Latossolo Roxo Distrófico, clima tropical úmido, com verão chuvoso e inverno seco, precipitação média anual entre 1200 e $1500 \mathrm{~mm}$, e temperaturas médias entre 21 e $22^{\circ} \mathrm{C}$. A fertilização da área de produção do capim foi previamente corrigida com $385 \mathrm{~kg} \mathrm{ha}^{-1} \mathrm{da}$ formula 30-00-20 (N-P-K) após o último corte, que antecedeu o experimento. Além da 
correção anual da concentração de fósforo para 30 ppm, corrigiu-se também a saturação de bases para $75 \%$ e a concentração de potássio para 5\% da CTC (capacidade de troca catiônica).

\subsection{Confecção da silagem emurchecida}

A silagem emurchecida do capim do Tifton 85 foi confeccionada, no intervalo de 15 a 21 de fevereiro, no ano de 2000. As condições climáticas predominantes nesses dias foram satisfatórias, com temperatura média de $26,6^{\circ} \mathrm{C}$ e umidade relativa do ar de $73 \%$. A forragem foi colhida com idade fisiológica, em torno de 35 dias de crescimento vegetativo, através de Segadeira Condicionadora CASE (modelo 8850 HP) equipada com condicionador de rolos de metal.

O material colhido foi submetido a períodos de emurchecimento visando obter níveis progressivos de matéria seca, na ensilagem. Quando o teor de matéria seca pretendido foi alcançado, o material foi picado (oito centímetros) e enfardado, utilizando-se uma Enfardadeira CLAAS (modelo Quadrant 1200 RC). Imediatamente, os fardos foram envolvidos com Filme Plástico Trioplast AB (modelo Triowrap, $750 \mathrm{~mm}$ x $0,25 \mathrm{~mm}$ ), aplicando-se seis camadas por fardo, com 50\% de sobreposição.

Os fardos confeccionados, com formato cúbico apresentavam as seguintes medidas: $140 \mathrm{~cm}$ de comprimento, $120 \mathrm{~cm}$ de largura e $70 \mathrm{~cm}$ de altura. $O$ peso, volume e densidade dos fardos, em seus respectivos tratamentos estão apresentados na Tabela 1.

As silagens teste consistiram de concentrações crescentes de matéria seca (MS) associadas ou não à aplicação de aditivo bacteriano-enzimático. Quatro concentrações de matéria seca $(20-30 \%, 40-50 \%, 50-60 \%, 60-70 \%)$ foram avaliadas sem o uso de aditivo.

Os tratamentos com a aplicação de aditivo SIL-ALL ${ }^{\circledR}$ foram constituídos de apenas três concentrações de matéria seca $(20-30 \%, 40-50 \%, 50-60 \%)$. 
Tabela 1. Valores relativos às médias do peso, volume e densidade dos fardos avaliados no experimento com ou sem aditivo bacteriano-enzimático.

\begin{tabular}{lccc}
\hline $\begin{array}{l}\text { TEOR MS } \\
(\%)\end{array}$ & $\begin{array}{c}\text { PESO } \\
(\mathrm{kg})\end{array}$ & $\begin{array}{c}\text { VOLUME } \\
\left(\mathrm{m}^{3}\right)\end{array}$ & $\begin{array}{c}\text { DENSIDADE } \\
\left(\mathrm{kg} / \mathrm{m}^{3}\right)\end{array}$ \\
\hline SEM ADITIVO (SA) & 364 & 1,18 & 310 \\
25SA & 368 & 1,18 & 313 \\
45SA & 344 & 1,18 & 292 \\
55SA & 254 & 1,18 & 216 \\
65SA & & \\
COM SIL-ALL(CA) & 352 & 1,18 & 300 \\
25CA & 329 & 1,18 & 280 \\
45CA & 294 & 1,18 & 250 \\
65CA & & & \\
\hline
\end{tabular}

O aditivo utilizado foi o produto comercial SIL-ALL ${ }^{\circledR}$, produzido pela empresa Alltech Inc. Este produto apresentou os seguintes níveis de garantia: 10 bilhões de ufc (unidades formadoras de colônias) de Streptococcus faecium $\mathrm{g}^{-1} ; 10$ bilhões de ufc de Lactobacillus plantarum $\mathrm{g}^{-1} ; 1$ bilhão de Pediococcus acidilactici $\mathrm{g}^{-1} \mathrm{e}$ as enzimas hemicelulase, celulase e amilase. A aplicação deste produto ocorreu na dose de 2,5 litros de uma solução a $0,5 \%$ (250 g de SIL-ALL ${ }^{\circledR}$ diluídos em 50 litros de água) por tonelada de forragem. A aplicação desta solução se deu através do uso de bomba de diafragma, ligada a dois bicos aspersores acoplados a plataforma de recolhimento da enfardadeira.

A silagem do capim Tifton 85 emurchecida foi transportada da Fazenda Água Comprida até o Setor de Ruminantes, Departamento de Produção Animal da ESALQ, em Piracicaba, local onde foi armazenada, do início até o final da experimentação, com o fornecimento diário e ininterrupto aos animais. 


\subsection{Período experimental, animais utilizados e ração teste}

O período experimental foi iniciado em maio de 2000, com duração de 119 dias, dividido em 7 períodos de 18 dias, sendo 11 dias para adaptação dos animais às dietas e 7 dias para coleta de amostras.

No ensaio experimental foram utilizados sete bovinos machos inteiros da raça Nelore, com peso médio de $330 \mathrm{~kg}$, portadores de cânulas ruminal e duodenal. Os animais foram alojados em baias individuais de 1,06 metros de largura, com comprimento ajustável de acordo com o tamanho do animal e provida de comedouro, bebedouro automático e piso emborrachado tipo "tie-stall".

Os animais foram pesados ao início e final de cada período experimental sendo suplementados com injeção intramuscular de um complexo vitamínico (ADEK), sob dosagem de acordo com as recomendações do fabricante.

Os tratamentos foram estudados considerando o fornecimento da ração contendo silagem de capim Tifton 85 (Cynodon dactylon spp.) com quatro concentrações de matéria seca $(20-30 \%, 40-50 \%, 50-60 \%, 60-70 \%)$ tratadas ou não antes da ensilagem, com um aditivo bacteriano-enzimático, à exceção a silagem contendo $50-60 \%$ de matéria seca, que foi avaliada exclusivamente.

As rações experimentais foram formuladas com base na composição da matéria seca (MS), segundo o NRC-gado de corte (1996), em função da variação das concentrações de matéria seca dos fardos. A participação da silagem emurchecida do capim Tifton 85 foi de $80 \%$ da ração e $20 \%$ de ingredientes concentrados com a finalidade de suprir as exigências do animal, evitando-se o efeito de substituição da forragem. Ao início de cada período experimental foi oferecido aos animais $5 \mathrm{~kg}$ de matéria seca $\mathrm{dia}^{-1}$, seguida de quantidades crescentes da ração de acordo com o aumento do consumo até sua estabilização. A composição da ração oferecida durante o experimento encontra-se na Tabela 2. 
Tabela 2. Composição percentual da ração experimental oferecida aos animais.

\begin{tabular}{lc}
\hline Ingredientes & \% da matéria seca \\
\hline Silagem emurchecida de Tifton 85 & 80,00 \\
Milho grão triturado & 17,08 \\
Farelo de Soja & 1,82 \\
$*$ Premix mineral- vitamínico & 1,10 \\
\hline
\end{tabular}

*Obs.: Suplemento mineral para bovinos de corte Q-65 (Qualimix).

Os tratamentos foram compostos das seguintes rações oferecidas, diariamente, aos animais, conforme relacionado abaixo:

1 Tratamento 25SA: Ração composta de silagem emurchecida entre 20-30\% MS, acrescida em $20 \%$ de concentrado.

2 Tratamento 25CA: Ração composta de silagem emurchecida tratada com aditivo SIL-ALL e com uma concentração de matéria seca entre 20-30\% MS, acrescida em $20 \%$ de concentrado.

3 Tratamento 45SA: Ração composta de silagem emurchecida entre 40-50\% MS, acrescida em $20 \%$ de concentrado.

4 Tratamento 45SA: Ração composta de silagem emurchecida tratada com aditivo SIL-ALL e com uma concentração de matéria seca entre 40-50\% MS, acrescida em $20 \%$ de concentrado.

5 Tratamento 55SA: Ração composta de silagem emurchecida entre 50-60\% MS, acrescida em $20 \%$ de concentrado.

6 Tratamento 65CA: Ração composta de silagem emurchecida entre 60-70\% MS, acrescida em $20 \%$ de concentrado.

7 Tratamento 65SA: Ração composta de silagem emurchecida tratada com aditivo SIL-ALL, com uma concentração de matéria seca entre 60-70\% MS, acrescida em $20 \%$ de concentrado. 
As rações totais foram fornecidas ad libitum, duas vezes ao dia, às 7:00 e 19:00 horas, sendo $60 \%$ da quantidade total no período matutino e $40 \%$ no período noturno, permitindo-se $5 \%$ de sobras. Estas foram pesadas diariamente, na parte da manhã, para ajustar o consumo de matéria seca. Amostras das rações completas e sobras foram coletadas nos últimos 7 dias de cada período de coleta e misturadas para formação de uma amostra composta ao final de cada período, e, posteriormente, acondicionadas em sacos plásticos e armazenadas a $-20^{\circ} \mathrm{C}$, para posteriores análises laboratoriais.

Ao final dos períodos de coleta, as amostras de ração completa e sobras armazenadas foram descongeladas, secadas em estufa de circulação forçada a $65^{\circ} \mathrm{C}$ por 48 horas e, posteriormente, submetidas às seguintes análises químico-bromatológicas: matéria seca $(\mathrm{MS})$ a $105^{\circ} \mathrm{C}$ durante 24 horas, proteína bruta $(\mathrm{PB})$, matéria mineral (MM), extrato etéreo (EE), (AOAC, 1980); fibra detergente neutro (FDN), fibra detergente acido (FDA), lignina (Van Soest et al., 1991) e avaliação do tamanho de partículas (Lammers et al., 1996). Todas as amostras de alimentos sofreram moagem, após a secagem, em moinho tipo Willey contra peneira de $1 \mathrm{~mm}$. Utilizou-se de duplicatas de amostras para determinação dos teores de MS, MM, PB e EE. A fração FDN foi determinada em duplicata por amostra, e a FDA em triplicata, utilizando-se o equipamento "Fiber Analyser Ankon 200" (Holden, 1999). A lignina foi determinada através do método LDA (lignina em detergente ácido) pelo uso de solução de ácido sulfúrico a 72\%, após a determinação de FDA, utilizando o equipamento "Daisy Incubator Ankon" (Holden, 1999).

Para a determinação do nitrogênio retido na fibra em detergente ácido (N-FDA) e em fibra detergente neutro (N-FDN) foi utilizado $1 \mathrm{~g}$ de amostra (Goering \& Van Soest, 1970). Após a determinação da fibra em detergente, esta foi submetida à análise em equipamento Macro Kjeldahl, conforme método de Kryshnamoorthy et al. (1983). Da dedução da concentração do N-FDA da fração N-FDN, obteve-se a estimativa da fração $\mathrm{B}_{3}$ da proteína, segundo o sistema proposto por Cornell. A fração celulose foi deduzida das frações hemicelulose e lignina.

As silagens foram avaliadas quanto ao desenvolvimento de micélios de fungos e produção de calor no painel, de exposição dos fardos, pelo método de avaliação visual, 
adotando-se uma escala de 1 a 4 sendo: 1) presença de fungos e leveduras em poucos pontos; 2) pequena incidência de colonização; 3) média colonização e 4) alta incidência de colônias dos mesmos. Foi avaliado, de maneira subjetiva, a produção de calor por intermédio de apalpação dos fardos e descartou-se as porções que apresentavam temperatura excessiva. Após a avaliação inicial dos fardos, foram coletadas as porções remanescentes dos fardos sem problemas aparentes e quantificadas para integrar as dietas dos animais. As parcelas quantificadas e descartadas constituíram um parâmetro quantitativo de perdas diárias para cada tratamento.

\subsection{Comportamento ingestivo}

No primeiro dia de cada período de avaliação, os animais foram observados por um período de 24 horas ininterruptos, iniciando-se após o fornecimento da dieta às 7:00 horas da manhã. As anotações foram tomadas a cada 5 minutos levando em consideração os aspectos de ingestão de alimentos e água, ruminação e ócio.

$\mathrm{Na}$ tentativa de eliminar o efeito da luminosidade sobre o comportamento animal, mantiveram-se apagadas as luzes do galpão, após o trato noturno (19:00 h). Foram utilizados feixes de luz, de uma lanterna, que foram direcionados indiretamente sobre a cabeça dos animais para realizar as observações previstas no experimento.

Para a avaliação do comportamento ingestivo dos animais houve a necessidade de transformar as medidas realizadas a cada intervalo de cinco minutos, para um minuto de observação. Para isso, dividiu-se o tempo total de ingestão de alimentos e água, ruminação e ócio, por cinco. O tempo de mastigação foi determinado somando-se o tempo de ingestão do alimento com o tempo de ruminação. Assim, para efeito de cálculo, o período de 24 horas de observação, foi transformado em minutos (1440 min).

Os cálculos das taxas de ingestão, ruminação e mastigação da matéria seca foram estimados pela divisão da quantidade média de matéria seca ingerida (kg) pelo tempo, em minutos, para cada unidade experimental, em cada período e em cada tratamento avaliado. A obtenção das taxas de ingestão, ruminação e mastigação da FDN foram 
estimadas pela multiplicação das respectivas taxas pela concentração de FDN na matéria seca efetivamente ingerida pelos animais.

\subsection{Determinação da consistência do conteúdo ruminal (Mat)}

No segundo dia de coleta, três horas após a oferta matinal de alimento (7:00 h), foi inserido um pêndulo de 500 gramas (fixo em um cordão de naylon) no saco dorsal do rúmen. Este, foi mantido no rúmen por um intervalo de uma hora para que a consistência do conteúdo ruminal fosse refeita através de movimentos peristálticos. A leitura foi efetuada por intermédio de um aparato inserido ao rúmen, constituído de uma haste metálica sustentando duas roldanas nas extremidades e dois pêndulos com pesos distintos, fixos nas extremidades de um cordão. A haste foi inserida horizontalmente na cânula ruminal e fixada na face lateral da cânula para suportar o pêndulo externo de 1500 gramas.

A leitura, propriamente dita, foi efetuada pela tração do cordão de naylon seguido pelo deslocamento do pêndulo externo, que foi posicionado ao lado de uma régua graduada, em centímetros, disposta verticalmente (presa em um tripé). Marcou-se a posição inicial do peso externo seguido de sua liberação e, simultaneamente, iniciou-se a contagem do tempo pelo uso de um cronômetro. A posição final foi obtida quando o pêndulo interno tocou a haste metálica disposta na posição horizontal, no interior do rúmen. Conseqüentemente, foi determinado o deslocamento do peso externo $(\mathrm{cm}) \mathrm{em}$

função do tempo (minutos) (Welch, 1982). Desta forma, a consistência do conteúdo ruminal pode ser analisada, em função do tempo (s) ou da velocidade de deslocamento (tempo/distância).

\subsection{Parâmetros ruminais}

No terceiro dia de coleta, amostras de líquido ruminal $( \pm 100 \mathrm{~mL})$ foram tomadas diretamente de quatro pontos distintos, na região ventral do rúmen. A primeira amostra foi retirada, antes da oferta de alimento matinal (7:00 horas) e as amostra subsequentes a 
cada 2 horas, por um período de 24 horas Assim os tempos de coleta foram estabelecidos nos horários $0,2,4,6,8,10,12,14,16,18,20$ e 22 horas. A digesta foi filtrada em tecido de algodão dobrado em quatro camadas, em seguida a parte sólida foi devolvida ao rúmen, e imediatamente o líquido ruminal foi homogenizado e o $\mathrm{pH}$ mensurado através de leitura direta com potenciômetro digital (Digimed TE-902).

Após a mensuração do $\mathrm{pH}$, uma alíquota de aproximadamente $50 \mathrm{~mL}$ foi inserida em dois frascos distintos e armazenados a $-20^{\circ} \mathrm{C}$, para posterior determinação de nitrogênio amoniacal $\left(\mathrm{N}-\mathrm{NH}_{3}\right)$ e ácidos graxos voláteis (AGV). Após o descongelamento, coletou-se uma alíquota do líquido ruminal, seguindo-se centrifugação a $12000 \mathrm{x} \mathrm{g}, 4^{\circ} \mathrm{C}$, durante 20 minutos. A fração sobrenadante foi utilizada para a determinação de $\mathrm{N}_{-} \mathrm{NH}_{3}$, de acordo com o método colorimétrico descrito por Chaney \& Marbach (1962) e adaptado para ser utilizado em placas de microtítulo e, posteriormente, mensuração em Colorímetro - Elisa Reader (absorbância de 550 nanômetros).

Para determinação dos AGVs foram coletados $8 \mathrm{~mL}$ da amostra do líquido ruminal e misturados a $2 \mathrm{~mL}$ de ácido metafosfórico 25\%. Esta mistura foi centrifugada a 12000 $\mathrm{x}$ g, a $4^{\circ} \mathrm{C}$, durante 20 minutos, retirado o sobrenadante para a determinação da concentração de AGVs de acordo com Palmquist \& Conrad (1971), utilizando-se do cromatógrafo líquido gasoso, CLG (Hewlett Packard 5890, series II), equipado com HP Integrator (Hewlett Packard Company, Avondale, PA). Como padrão interno foi utilizado a solução do ácido 2-etilbutírico, composta por $10 \mathrm{~mL}$ de álcool etanol, 1,16g de ácido 2-etilbutírico e $30 \mathrm{~mL}$ de água deionizada. O gás de arraste e os comburentes foram nitrogênio, hidrogênio e oxigênio, respectivamente, e nas razões de 20, 30, e 400 $\mathrm{mL} \min ^{-1}$. A temperatura do injetor, detector e coluna, foram 150,190 e $115^{\circ} \mathrm{C}$, respectivamente. Em cada frasco de leitura no cromatógrafo, foram adicionados $100 \mu \mathrm{L}$ do padrão composto pelo AGVs referência e o padrão interno, $1000 \mu \mathrm{L}$ do sobrenadante após a centrifugação, que foi composto por $800 \mu \mathrm{L}$ de líquido ruminal e $200 \mu \mathrm{L}$ de ácido metafosfórico. As concentrações de AGVs foram corrigidas pelo fator 1,25 obtido pela adição de solução de ácido metafosfórico $25 \%$. 


\subsection{Avaliação da taxa de passagem}

Em cada período de avaliação, no quarto dia, foram introduzidos no rúmen $100 \mathrm{~g}$ amostra de silagem de capim Tifton 85 marcada com cromo mordente, antes da alimentação matutina dos animais com o objetivo de se determinar a taxa de passagem dos sólidos da digesta ruminal. Simultaneamente, 3 g de Co-EDTA diluídos em 1000 $\mathrm{mL}$ de água, foram introduzidos no rúmen para determinação da taxa de passagem da fase líquida ruminal. A obtenção da fibra marcada foi realizada de acordo com metodologia descrita por Udén et al. (1980).

Amostra de fezes foram coletadas diretamente do reto dos animais nos tempos 0 , $6,12,18,24,30,36,42,48,54,60,66,72,78,84,90$, e 96 horas após o fornecimento dos marcadores, com o objetivo de obter as concentrações de Cr e Co-EDTA, nas fezes, para posterior análise laboratorial para estimar a taxa de passagem.

As concentrações de $\mathrm{Cr}$ e Co-EDTA, nas fezes, foram determinadas através leitura em Raio-X, no Laboratório de Instrumentação Nuclear, Centro de Energia Nuclear na Agricultura da USP (CENA). O método utilizado para a determinação dos marcadores Cr e Co baseou-se na técnica de fluorescência em Raio-X, segundo Korndörfer (1999). Para o cálculo da taxa de passagem, independente do marcador, houve a necessidade de transformar as concentrações de Cr e Co-EDTA em valores relativos. Para cada animal, dentro de cada período e tratamento, assumiu-se o valor relativo de $100 \%$ para aquele que apresentou maior valor de leitura de Raio-X, na concentração de marcadores. As

demais leituras foram determinadas em função do maior valor percentual obtido na transformação da leitura de Raio-X. A partir da maior leitura, determinou-se a porção linear da curva descrita pelos valores de LN [Co] e LN [Cr] e, desta, obteve-se o coeficiente angular $(\operatorname{tg} \alpha=(\Delta y / \Delta x) * 100)$ que representou a taxa se passagem $(\mathrm{Kp})$ (Firkins et al., 1986). 


\subsection{Avaliação da digestibilidade aparente}

As determinações das digestibilidades aparente da MS, matéria orgânica, proteína bruta, FDN, FDA e hemicelulose no trato total, foram realizadas mediante pesagem total das fezes produzidas pelos animais, nos últimos quatro dias de cada período experimental, e somadas com o peso das amostras retiradas para análise da taxa de passagem.

As fezes foram quantificadas duas vezes ao dia (7:00 e 19:00 h), homogeneizadas e amostradas em $5 \%$ do total de cada pesagem. Estas amostras foram congeladas $\left(-20^{\circ} \mathrm{C}\right)$ e agrupadas por período do experimento e identificadas por animal, para posteriores análises de MS, MN, PB, FDN, FDA e lignina.

Para efeito de cálculo, a fórmula utilizada foi:

$$
\text { Digestibilidade }=\frac{(\text { Oferecido }- \text { Sobras })-F e z e s}{(\text { Oferecido-Sobras })} \times 100
$$

\subsection{Modelo estatístico}

O delineamento experimental adotado foi o quadrado latino $7 \times 7$, com sete tratamentos e sete períodos de avaliação.

Os resultados de parâmetros ruminais foram testados como medidas repetidas no tempo utilizando o procedimento PROC MIX, enquanto os demais foram analisados pelo procedimento GLM. Para efeito de análise, primeiramente, as variáveis animais, períodos e tratamentos foram submetidas ao teste de análise de variância. Utilizou-se o teste de comparação de médias dos quadrados mínimos para as médias dos tratamentos que apresentaram diferenças significativas a 5\% de probabilidade.

Dentro dos grupos de tratamento SA e CA foram testadas relações funcionais para os efeitos linear e quadrático e as interações destes, para as silagens com os teores crescentes de MS. 
O modelo matemático utilizado para analisar os resultados experimentais, através do programa SAS (1988), foi:

$\mathrm{Y}_{\mathrm{ijklm}}=\mu+\mathrm{U}_{\mathrm{i}}+\beta_{\mathrm{j}}+\mathrm{P}_{1}+\mathrm{V}_{\mathrm{m}}+(\mathrm{T} \beta)_{\mathrm{ij}}+(\mathrm{PV})_{\mathrm{lm}}+\mathrm{e}_{\mathrm{ijklm}}$

Onde:

$\mu=$ média geral

$\mathrm{U}_{\mathrm{i}}=$ efeito da porcentagem de matéria seca

$\beta_{\mathrm{j}}=$ efeito do aditivo

$(\mathrm{T} \beta)_{\mathrm{ij}}=$ efeito da interação matéria seca $\mathrm{x}$ aditivo

$\mathrm{P}_{1}=$ efeito do período

$\mathrm{V}_{\mathrm{m}}=$ efeito do animal

$(\mathrm{PV})_{\operatorname{lm}}=$ interação período $\mathrm{x}$ animal

$\mathrm{e}_{\mathrm{ijklm}}=$ efeito residual 


\section{RESULTADOS E DISCUSSÃO}

\subsection{Composição bromatológica das rações experimentais}

Reconhecendo que o concentrado compôs $20 \%$ da matéria seca de todas as rações experimentais, e com o intuito de se prever com maior acurácia, as possíveis mudanças na composição físico-química das silagens, a análise bromatológica do concentrado foi realizada separadamente e, pode ser observada na Tabela 3.

A partir da avaliação dos dados apresentados na Tabela 3, pode-se concluir que a concentração média de matéria seca esperada não foi precisamente atingida em todas as silagens experimentais, em decorrência das dificuldades operacionais na confecção dos fardos, existindo uma amplitude de variação entre os fardos, do mesmo tratamento, conforme Tabelas 3 e 4 . Por esta razão, resolveu-se preservar o objetivo inicial deste trabalho, mantendo os teores planejados para comparação $(25,45$ e $65 \%$ de MS) associados ou não ao inoculante bacteriano-enzimático, e um tratamento adicional contendo apenas a silagem exclusiva com 55\% de MS, assim denominados: 25SA, 45SA, 55SA, 65SA e 25CA, 45CA e 65CA.

A concentração de matéria seca das silagens apresentou-se significativamente $(\mathrm{P}=$ $0,01)$ diferente. Porém, a comparação de médias pelo teste $(\mathrm{t})$, geradas pelo procedimento PROC GLM do programa SAS, não detectou compatibilidade entre os teores médios de matéria seca das seguintes silagens: 25SA (32,3\%) com 25CA (25,3\%) e $65 \mathrm{SA}(65,7 \%)$ com $65 \mathrm{CA}(55,8 \%)$. Houve, entretanto, compatibilidade para os seguin- 
Tabela 3. Médias das variáveis de composição bromatológica observadas para ingredientes concentrados e para as silagens de capim Tifton 85.

\begin{tabular}{|c|c|c|c|c|c|c|c|c|c|c|c|c|c|c|}
\hline \multirow[t]{2}{*}{ Variável } & \multirow[t]{2}{*}{$\operatorname{Con}^{1}$} & \multicolumn{3}{|c|}{ Silagem com aditivo } & \multicolumn{4}{|c|}{ Silagem sem aditivo } & \multirow[t]{2}{*}{$\mathbf{C V}$} & \multicolumn{5}{|c|}{ Contrastes $^{2}(\mathrm{P}<)$} \\
\hline & & 25 & 45 & 65 & 25 & 45 & 55 & 65 & & $\mathbf{L}$ & $\mathbf{Q}$ & AD & $\mathbf{L} * \mathbf{A D}$ & Q*AD \\
\hline $\mathrm{MS}^{3}$ & 85,3 & $32,3^{\mathrm{d}}$ & $48,0^{\mathrm{c}}$ & $55,8^{b}$ & $25,3^{\mathrm{e}}$ & $44,7^{\mathrm{c}}$ & $52,7^{\mathrm{bc}}$ & $65,7^{\mathrm{a}}$ & 9 & 0,01 & 0,01 & 0,13 & 0,01 & 0,52 \\
\hline $\mathrm{MO}^{3}$ & 80,4 & $29,7^{\mathrm{e}}$ & $44,1^{\mathrm{cd}}$ & $51,5^{\mathrm{b}}$ & $24,7^{\mathrm{f}}$ & $41,1^{\mathrm{d}}$ & $48,3^{b c}$ & $60,5^{\mathrm{a}}$ & 18 & 0,01 & 0,01 & 0,16 & 0,01 & 0,52 \\
\hline $\mathrm{MM}^{3}$ & 5,8 & $8,1^{\mathrm{bc}}$ & $8,2^{\mathrm{bc}}$ & $7,7^{\mathrm{c}}$ & $8,8^{\mathrm{a}}$ & $8,0^{\mathrm{bc}}$ & $8,4^{\mathrm{ab}}$ & $7,9^{\mathrm{c}}$ & 6 & 0,02 & 0,41 & 0,79 & 0,01 & 0,63 \\
\hline $\mathrm{PB}^{3}$ & 11,3 & $10,5^{\mathrm{a}}$ & $10,8^{\mathrm{a}}$ & $10,4^{\mathrm{a}}$ & $12,0^{\mathrm{a}}$ & $11,2^{\mathrm{a}}$ & $11,1^{\mathrm{a}}$ & $10,8^{\mathrm{a}}$ & 10 & 0,23 & 0,94 & 0,23 & 0,01 & 0,92 \\
\hline $\mathrm{CNF}^{3}$ & 68,1 & $8,2^{\mathrm{ab}}$ & $8,5^{\mathrm{ab}}$ & $9,5^{\mathrm{a}}$ & $9,4^{\mathrm{ab}}$ & $9,2^{\mathrm{ab}}$ & $7,8^{\mathrm{b}}$ & $6,0^{\mathrm{c}}$ & 17 & 0,80 & 0,90 & 0,01 & 0,63 & 0,46 \\
\hline $\mathrm{EE}^{3}$ & 1,6 & $1,5^{\mathrm{c}}$ & $1,6^{b c}$ & $1,6^{\mathrm{bc}}$ & $1,8^{\mathrm{a}}$ & $1,8^{\mathrm{a}}$ & $1,7^{\mathrm{ab}}$ & $1,5^{\mathrm{c}}$ & 9 & 0,77 & 0,75 & 0,01 & 0,01 & 0,35 \\
\hline $\mathrm{FDN}^{3}$ & 13,3 & $71,7^{\mathrm{b}}$ & $71,0^{\mathrm{b}}$ & $70,8^{\mathrm{b}}$ & $67,9^{\mathrm{c}}$ & $69,8^{\mathrm{bc}}$ & $70,9^{b}$ & $73,9^{\mathrm{a}}$ & 3 & 0,13 & 0,90 & 0,01 & 0,02 & 0,57 \\
\hline FDA $^{3}$ & 10,1 & $49,0^{\mathrm{a}}$ & $49,2^{\mathrm{a}}$ & $50,5^{\mathrm{a}}$ & $48,6^{\mathrm{a}}$ & $46,2^{\mathrm{a}}$ & $50,0^{\mathrm{a}}$ & $49,0^{\mathrm{a}}$ & 7 & 0,28 & 0,12 & 0,35 & 0,76 & 0,20 \\
\hline $\mathrm{CEL}^{3}$ & 9,1 & $33,8^{\mathrm{a}}$ & $30,4^{\mathrm{a}}$ & $30,5^{\mathrm{a}}$ & $40,4^{\mathrm{a}}$ & $29,9^{\mathrm{a}}$ & $28,2^{\mathrm{a}}$ & $29,8^{\mathrm{a}}$ & 28 & 0,03 & 0,30 & 0,31 & 0,52 & 0,41 \\
\hline $\mathrm{HEMI}^{3}$ & 3,1 & $22,6^{\mathrm{a}}$ & $21,8^{\mathrm{a}}$ & $20,4^{\mathrm{a}}$ & $19,3^{\mathrm{a}}$ & $23,6^{\mathrm{a}}$ & $20,9^{\mathrm{a}}$ & $24,9^{\mathrm{a}}$ & 18 & 0,81 & 0,15 & 0,59 & 0,36 & 0,16 \\
\hline $\mathrm{LIG}^{3}$ & 1,0 & $7,8^{\mathrm{a}}$ & $7,7^{\mathrm{a}}$ & $8,0^{\mathrm{a}}$ & $6,8^{\mathrm{b}}$ & $6,8^{\mathrm{b}}$ & $7,6^{\mathrm{a}}$ & $7,9^{\mathrm{a}}$ & 9 & 0,05 & 0,22 & 0,03 & 0,01 & 0,19 \\
\hline N-FDN ${ }^{3}$ & 41,2 & $27,6^{\mathrm{d}}$ & $29,7^{\mathrm{d}}$ & $39,0^{\mathrm{ab}}$ & $18,5^{\mathrm{e}}$ & $30,6^{\mathrm{cd}}$ & $34,9^{\mathrm{bc}}$ & $44,0^{\mathrm{a}}$ & 14 & 0,01 & 0,92 & 0,34 & 0,01 & 0,28 \\
\hline N-FDA ${ }^{3}$ & 3,0 & $7,6^{\mathrm{a}}$ & $5,7^{\mathrm{b}}$ & $5,6^{\mathrm{b}}$ & $6,2^{\mathrm{ab}}$ & $5,4^{\mathrm{b}}$ & $5,7^{\mathrm{b}}$ & $5,4^{\mathrm{b}}$ & 22 & 0,02 & 0,11 & 0,18 & 0,22 & 0,65 \\
\hline $\mathrm{B}_{3}{ }^{4}$ & 38,2 & $20,0^{\mathrm{d}}$ & $24,1^{\mathrm{c}}$ & $33,0^{\mathrm{b}}$ & $12,3^{\mathrm{e}}$ & $25,1^{\mathrm{c}}$ & $29,2^{b c}$ & $38,6^{\mathrm{a}}$ & 17,5 & 0,01 & 0,53 & 0,51 & 0,01 & 0,33 \\
\hline
\end{tabular}

\footnotetext{
${ }^{1}$ Análise bromatológica do concentrado.

${ }^{2}$ Contrastes = L: matéria seca efeito linear; Q: matéria seca efeito quadrática; AD: efeito aditivo; L*AD: interação matéria seca linear e aditivo; $\mathrm{Q}^{*} \mathrm{AD}$ : interação matéria seca quadrática e aditivo.

${ }^{3}$ Matéria seca (MS) em \%, matéria orgânica (MO) em \%, matéria mineral (MM) em \% MS, proteína bruta (PB) em \% MS, carboidrato não fibroso (CNF) em \% MS, extrato etéreo (EE) em \% MS, fibra detergente neutro (FDN) em \% MS, fibra detergente ácido (FDA) em \% MS, celulose (CEL) em \% MS, hemicelulose (HEMI) em \% MS, lignina (LIG) em \% MS, N-FDN em \% N total e N-FDA em \% N total.

${ }^{4} \mathrm{~B}_{3}(\mathrm{NxFDN}-\mathrm{NxFDA} / \mathrm{N}$ total $\mathrm{x} 100)$.
} 
tes tratamentos 45SA $(44,7 \%)$ com 45CA $(48,0 \%)$, 45CA $(48,0 \%)$ com 55SA $(52,7 \%)$ e 55SA $(52,7 \%)$ com 65CA $(55,8 \%)$.

As silagens testadas apresentaram uma tendência melhor apresentada pela equação linear $(\mathrm{P}=0,01)$, com comportamento distinto para a presença de aditivo $(\mathrm{P}=0,01)$ sob determinados teores de MS. Pode-se dizer que o processo de desidratação de forragens pelo método do emurchecimento se mostrou eficiente na adequação do capim Tifton 85 para ensilagem, contudo é válido enfatizar que condições meteorológicas e uso de equipamentos apropriados são fatores de suma importância para a qualidade do produto (Reis \& Rodrigues, 1998 e Vilela, 1984).

Os menores teores de cinzas observados para as silagens contendo maior concentração de matéria seca, indicam um possível padrão de fermentação mais adequado nesses fardos. Apesar de se reconhecer que a respiração é uma importante forma de perda de carboidratos, e que esta ocorre mais significativamente nas silagens com maior teor de MS (65), existe por outro lado, a maior produção de efluentes e as fermentações indesejáveis como formas prejudiciais de consumo de açúcares em silagens mais úmidas. Na Tabela 3, as maiores concentrações de cinzas, nos tratamentos contendo silagens mais úmidas, possivelmente refletiram a ponderação das perdas e a presença de maior umidade na silagem determinou maior consumo de carboidratos resultando em maior concentração da fração mineral.

A análise da variável carboidratos não fibrosos (CNF) apresentada na Tabela 3 indica que houve efeito de aditivos e que as diferentes concentrações de MS não responderam uniformemente ao aditivo. As silagens inoculadas apresentaram média de $8,7 \%$ CNF e as não inoculadas de $8,1 \%$, contrariando a expectativa. Em geral, silagens inoculadas tem sua fração de carboidratos solúveis reduzida em decorrência da maior produção de ácidos orgânicos.

Para os constituintes da fibra, o teste F para a fração FDN, indicou diferença significativa, provavelmente, devido a esta fração ser mais representativa, e mais afetada pelo emurchecimento e, principalmente, devido a menor variação no teor de matéria seca entre fardos deste tratamento. Houve tendência $(\mathrm{P}=0,13)$ linear para o aumento no teor de FDN com o aumento na concentração de MS, que poderia ser justificado pela 
respiração de CNF durante a desidratação dos tratamentos. Contudo, essa tendência não foi verificada para os CNF. Além disso, as silagens inoculadas apresentaram maior teor de $\operatorname{FDN}(72,7 \%)$ em relação as não inoculadas $(70,8 \%)$ que também poderia sugerir o maior consumo de $\mathrm{CNF}$, nos tratamentos contendo inoculante. Uma vez que essa não foi a tendência da fração $\mathrm{CNF}$, os maiores teores de componentes de parede celular em silagens inoculadas não podem ser explicados pelo desaparecimento da fração de CNF.

Castro (2002) avaliando o uso de emurchecimento e uso do inoculante bacteriano enzimático na produção de silagem de Tifton 85 verificou decréscimo $(\mathrm{P}<0,05)$ do teor de FDN com o aumento da concentração de matéria seca das silagens, no primeiro instante até 16 dias após a ensilagem. No entanto, esse parâmetro sofreu acréscimo $(\mathrm{P}<0,05)$ com o incremento do conteúdo de matéria seca aos 8 e 32 dias. Aos 90 e 180 dias de estocagem, não houve diferença significativa $(\mathrm{P}>0,05)$, entre os tratamentos. As observações de Castro (2002) se deram com as mesmas silagens utilizadas no presente trabalho, e o início desta experimentação se fez após 60 dias de estocagem. Este fato possivelmente explica a interação linear entre matéria seca e aditivo $(\mathrm{P}<0,05)$, bem como o efeito do aditivo $(\mathrm{P}<0,05)$ para a variável $\mathrm{FDN}$ e a rápida estabilização desta fração em silagens inoculadas, antes do início da fase experimental.

De acordo com Castro (2002), observou-se aumento da fração N-FDN para silagens com conteúdo de matéria seca elevado, demonstrando maior preservação desta fração nas silagens. Esta observação está de acordo com o presente trabalho onde ambas, silagens exclusivas ou inoculadas tinham a fração N-FDN aumentada com a maior concentração de MS. Castro (2002), verificou redução dos conteúdos de N-FDN entre 8 e 90 dias para silagens inoculadas, indicando talvez que o tempo de estocagem altere a composição desta fração, contudo no presente experimento não se verificou diferença significativa $(\mathrm{P}>0,05)$ para período experimental. $\mathrm{A}$ fração $\mathrm{B}_{3}$ nas silagens apresentou tendência de aumento com a elevação da concentração de MS, em função da progressiva elevação da concentração da fração $\mathrm{N}$ insolúvel no FDN, simultaneamente à redução do N insolúvel no FDA.

As frações FDA e hemicelulose não sofreram alteração com a variação na concentração de MS das silagens ou com a inoculação. A fração celulose foi 
significativamente $(\mathrm{P}=0,03)$ reduzida com a maior concentração de MS. Contrariamente, a fração lignina sofreu incremento significativo $(\mathrm{P}=0,05)$ com o maior teor de MS da silagem. A fração N-FDA acompanhou a tendência da fração celulose e foi reduzida com a menor umidade da silagem.

Segundo Castro (2002) o emurchecimento elevou $(\mathrm{P}<0,05)$ a concentração de lignina durante os primeiros 90 dias após a ensilagem, e o uso de inoculante bacterianoenzimático reduziu a concentração deste composto até o décimo sexto dia de estocagem, não tendo efeito $(\mathrm{P}>0,05)$ nos demais períodos de amostragem. Os valores referentes à lignina apresentaram efeito para aditivo e interação linear entre matéria seca e aditivo. Assim, não destoaram dos resultados obtidos por Castro (2002), pois no período em que, provavelmente, ocorreram estas transformações as silagens ainda se encontravam armazenadas.

A colheita e estocagem de gramíneas e leguminosa como silagens ou fenos, é suscetível à alteração na composição bromatológica, uma vez que as perdas dos vários componentes não são homogêneas e proporcionais. Durante a ensilagem, perde-se parte da fração proteína e por isso, é importante conhecer quanto de proteína é convertida em nitrogênio não protéico. As forragens submetidas ao emurchecimento prévio, geralmente têm sua fração protéica melhor preservadas que aquelas obtidas pelo corte direto. Contudo, o emurchecimento também promove uma considerável alteração na fração protéica decorrente da respiração da planta (Lucci, 1997).

A concentração de proteína bruta não apresentou alteração significativa $(\mathrm{P}>0,05)$ contudo, houve elevação linear das frações N-FDN $(\mathrm{P}=0,01)$ e $\mathrm{B}_{3}(\mathrm{P}=0,01)$ com $\mathrm{o}$ aumento da matéria seca, além de um efeito adicional do inoculante para as silagens que o continham. Efeito inverso pode ser notado na fração N-FDA apenas para o aumento de matéria seca, contrariando as observações de Castro (2002) que verificou aumento no teor de nitrogênio insolúvel em detergente ácido, para as silagens com elevado teor de matéria seca, assim como para o uso do inoculante bacteriano-enzimático $(\mathrm{P}<0,05)$, durante os primeiros 32 dias de armazenagem. O efeito do emurchecimento sobre a proteólise deve-se, possivelmente, a menor concentração de água que impede a ação enzimática. 
Pedreira et al. (2001) avaliando as características químicas e fermentativas do capim Tifton 85, ensilado com diferentes teores de matéria seca, pela inclusão de diferentes percentuais de polpa cítrica e/ou pelo emurchecimento, verificaram que ambas as técnicas, associadas ou não, acarretaram no aumento nos teores de matéria seca e de carboidratos solúveis da planta. Os teores de FDN diminuíram, enquanto os de FDA aumentaram, durante a fermentação de todas as silagens. Devido as diferenças na idade fisiológica da planta no momento do corte, no tempo de desidratação e na escolha do aditivo, os teores de FDN daquele trabalho se mantiveram um pouco acima da média dos tratamentos aqui testados, contudo situação inversa foi constatada para os teores de FDA.

Vilela et al. (2001) fazendo uso da técnica de emurchecimento na ensilagem de capim elefante Paraíso, encontraram 17,5\% MS para silagem controle, 25,6\% MS para o emurchecimento por seis horas e $31,2 \%$ MS para o emurchecimento por doze horas. O emurchecimento por seis horas não influenciou o teores de FDN, FDA, e proteína bruta quando comparado ao controle, enquanto o emurchecimento por doze horas reduziu os teores de FDN e proteína bruta, além de resultar em menor produção de ácido lático, amônia e menor valor da digestibilidade in vitro da matéria seca. Aguiar et al. (2001) verificou que os tratamentos com o emurchecimento produziram o mesmo efeito da adição de polpa cítrica, em reduzir o teor de umidade de silagem de capim Tanzânia, como também foram observados maiores teores de proteína quando comparados aos tratamentos sem adição de polpa cítrica e sem emurchecimento.

Coan et al. (2001) verificaram maiores teores de matéria seca, FDN, FDA para silagens de capim Tanzânia e menores de proteína bruta, nitrogênio amoniacal quando comparada às de mombaça. Os valores de hemicelulose, lignina, e a digestibilidade in vitro da matéria seca foram similares para ambas as espécies. $\mathrm{O}$ uso do inoculante bacteriano-enzimático não melhorou as características qualitativas, fermentativas e nutricionais das silagens avaliadas, independente da espécie forrageira e da idade de corte. Além disso, o uso do inoculante bacteriano-enzimático manteve a concentração de carboidratos não fibrosos e de FDN estável em todas concentrações de matéria seca testadas, indicando melhor característica fermentativa para estas silagens. 


\subsection{Eficiência de utilização das silagens}

No decorrer do período experimental, pôde-se notar grande variação na ocorrência de perdas entre fardos, independente do tratamento. Estas perdas, provavelmente, iniciaram-se no campo, devido a aceleração da respiração celular provocada pela temperatura ambiente. A maior suscetibilidade a perdas também pode estar associada à contaminação do material ceifado, por colônias de microrganismos indesejáveis, geralmente do gênero Clostridium, associados a partículas de solo, prejudicando o padrão de fermentação da silagem. Assim, a perda da estabilidade aeróbica dos fardos após sua abertura, é fruto da interação entre espécie forrageira, microrganismos, clima, equipamentos, manejo de retirada da silagem e presença de oxigênio residual.

A deterioração aeróbica diminui o valor nutricional da silagem, e pode conferir alterações sensoriais, como a menor palatabilidade. Uma grave consequência da deterioração aeróbica é resultante de mudanças químicas que podem permitir a proliferação de patógenos prejudiciais aos animais (Ruxton \& Gibson, 1995).

A forma geométrica do silo gera impacto sobre a qualidade da silagem (Ruxton \& Gibson, 1995). Em silagens revestidas por lona plástica, na forma de fardos retangulares, o teor de matéria seca exerce influência direta no grau de compactação da silagem, que representa um mecanismo eficiente para eliminar a presença de oxigênio, possibilitando condições propícias de armazenagem. Após a abertura dos fardos, a perda de tensão exercida pela amarração que mantinha a compressão, torna-os menos densos e mais suscetíveis aos danos causados pela entrada de ar no sistema, principalmente pelo desenvolvimento de fungos e leveduras.

Este fato pode ser observado na Figura 1, onde são apresentadas perdas médias dos tratamentos, 25SA (12,1\%), 25CA (22,3\%), 45SA (28,6\%), 45CA (22,8\%), 55SA $(27,4 \%), 65 \mathrm{SA}(26,1 \%)$ e $65 \mathrm{CA}(32,9 \%)$. Ao agrupar as médias pela concentração de MS da silagem obteve-se $25(17,2 \%), 45(25,7 \%), 55(27,4)$ e $65(29,1 \%)$ de perdas, indicando tendência de elevação com o aumento na concentração de MS da silagem. Esta observação é coerente com dados sobre a técnica de emurchecimento obtidos por Vilela (1984) que associa perdas decorrentes da dificuldade de compactação do capim 
elefante com alta concentração de matéria seca. A avaliação de perdas influenciada pelo uso do inoculante bacteriano-enzimático se fez através da comparação entre silagens com concentrações similares, onde o efeito benéfico só pode ser observado com o uso do inoculante bacteriano-enzimático para o teor de 45\% MS.

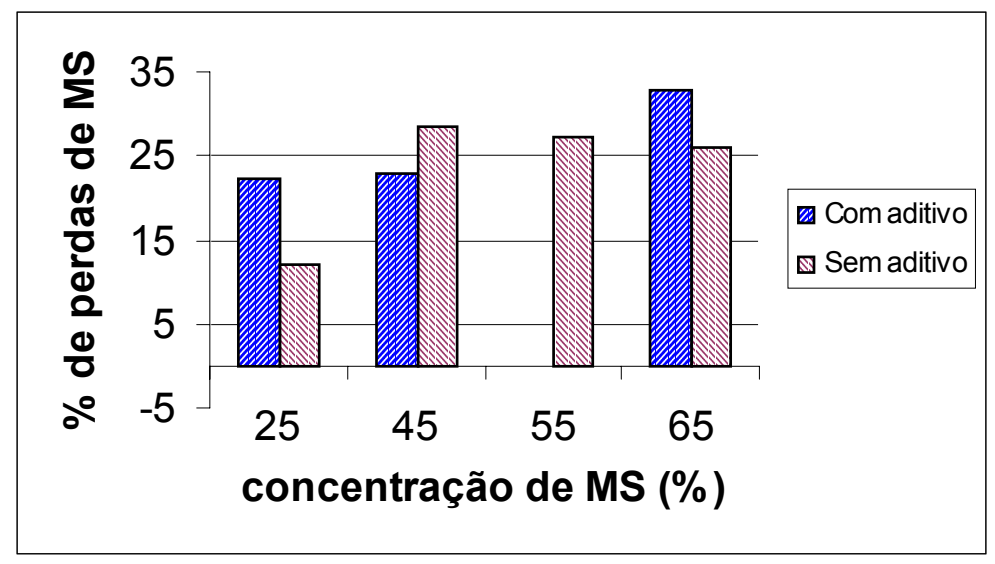

Figura 1 - Porcentagem de perdas em matéria seca nos fardos contendo silagens de capim Tifton 85 comparadas sob efeito de aditivo bacteriano-enzimático e de concentrações de MS.

A maior densidade da silagem proporciona dois importantes eventos: diminuir o volume de ocupação e preencher com o teor de matéria seca (massa) da forragem sua porosidade, conseqüentemente, diminuir as perdas na armazenagem, e inibir a deterioração após abertura do silo, contribuindo para redução no custo anual de armazenamento por tonelada de forragem. De acordo com Holmes \& Muck (1999) uma densidade de $225 \mathrm{~kg} \mathrm{MS} \mathrm{m}^{-3}$ pode ser considerada como o limite mínimo para que sejam evitadas perdas de MS advindas da compactação deficiente. Esta abordagem é coerente com a densidade média atingida para a maior parte da silagens e pode ser observada na Tabela 1. A elevação da concentração de matéria seca na ensilagem de Tifton 85, através da técnica de emurchecimento, proporcionou queda da densidade dos fardos, que possivelmente favoreceu a incidência de agentes negativos à conservação da silagem. 
Tabela 4. Médias dos quadrados mínimos para as variáveis de eficiência de utilização de fardos contendo silagens de capim Tifton 85.

\begin{tabular}{|c|c|c|c|c|c|c|c|c|c|}
\hline \multirow[t]{2}{*}{ Variáveis } & \multicolumn{3}{|c|}{ Com aditivo } & \multicolumn{4}{|c|}{ Sem aditivo } & \multirow[t]{2}{*}{$\mathbf{C V}$} & \multirow{2}{*}{$\begin{array}{r}\text { Trat }^{2} \\
(\mathbf{P}<)\end{array}$} \\
\hline & 25 & 45 & 65 & 25 & 45 & 55 & 65 & & \\
\hline MS observada, $\%$ & $34,2^{\mathrm{d}}$ & $47,5^{\mathrm{c}}$ & $59,1^{b}$ & $28,3^{\mathrm{e}}$ & $48,5^{\mathrm{c}}$ & $55,3^{b}$ & $69,1^{\mathrm{a}}$ & 9,8 & 0,01 \\
\hline Peso fardos, kg & $301,2^{\mathrm{a}}$ & $299,4^{\mathrm{a}}$ & $280,1^{\mathrm{a}}$ & $294,1^{\mathrm{a}}$ & $296,3^{\mathrm{a}}$ & $335,8^{\mathrm{a}}$ & $252,9^{\mathrm{a}}$ & 24,9 & 0,52 \\
\hline Peso MS fardos, kg & $102,9^{c}$ & $144,1^{b}$ & $163,1^{\mathrm{ab}}$ & $93,3^{\mathrm{c}}$ & $151,0^{\mathrm{ab}}$ & $186,6^{\mathrm{a}}$ & $172,5^{\mathrm{ab}}$ & 26,1 & 0,01 \\
\hline Perdas MS no fardo, $\%$ & $27,1^{\mathrm{cd}}$ & $33,0^{\mathrm{bc}}$ & $54,2^{\mathrm{a}}$ & $11,2^{\mathrm{d}}$ & $41,2^{\mathrm{abc}}$ & $60,4^{\mathrm{a}}$ & $46,7^{\mathrm{ab}}$ & 55,8 & 0,01 \\
\hline Tempo de utilização dos fardos, dias & $9,9^{\mathrm{b}}$ & $11,7^{\mathrm{ab}}$ & $12,9^{\mathrm{ab}}$ & $10,5^{\mathrm{b}}$ & $11,0^{\mathrm{ab}}$ & $14,6^{\mathrm{a}}$ & $12,7^{\mathrm{ab}}$ & 30,4 & 0,08 \\
\hline Escore contaminação fúngica & $1,4^{\mathrm{a}}$ & $1,0^{\mathrm{ab}}$ & $1,3^{\mathrm{a}}$ & $0,7^{\mathrm{b}}$ & $1,1^{\mathrm{ab}}$ & $1,1^{\mathrm{ab}}$ & $1,1^{\mathrm{ab}}$ & 49,0 & 0,08 \\
\hline
\end{tabular}

${ }^{1}$ Escore $(1=$ presença de fungos e leveduras em poucos pontos, $2=$ pequena incidência de colonização, $3=$ média colonização e 4= alta incidência de colonização).

${ }^{2}$ Teste $\mathrm{F}$ para o efeito de tratamento. 


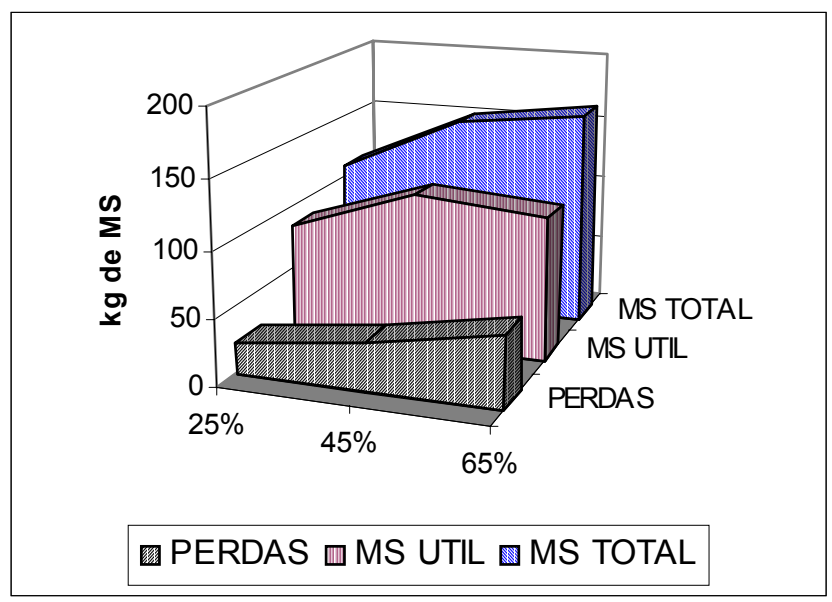

Figura 2 - Quantidade $(\mathrm{kg})$ de matéria seca útil, perdida e total contida nos fardos tratados com inoculante bacteriano-enzimático sob diferentes concentrações de MS.

O número de fardos utilizados por tratamento 25SA (12), 25CA (13), 45SA (11), 45CA (11), 55SA (9), 65SA (10) e 65CA (10), também pode ser associado ao teor de matéria seca, conforme as variáveis de eficiência apresentadas na Tabela 4. O peso dos fardos na matéria natural, não diferem significativamente, contudo com o progressivo aumento da concentração de matéria seca, houve elevação na densidade de MS nos fardos. É curioso que com o aumento na concentração de MS, da silagem, seria esperado menor número de fardos utilizados para o tratamento 65\% MS. Entretanto, ao considerar a maior incidência de descarte involuntário dos fardos contendo este tratamento, identificou-se uma maior utilização destes fardos.

Com relação aos motivos de descarte dos fardos, pode ser notado nas Figuras 2, 3, 4, 5 e na Tabela 4 que, com o aumento no teor de matéria seca houve maior freqüência de silagens descartadas involuntariamente. Uma possível explicação para a elevação nas perdas em silagens com maior teor de MS, se deve a menor quantidade de silagem retirada nesses fardos, uma vez que cada unidade experimental era composta de apenas um animal, determinando assim reduzida taxa e intensidade de retirada do painel nesses fardos. 
Observações de perdas nos painéis dos silos, levaram a constatação, principalmente na retirada de silagem pela manhã, que os pontos mais danificados se encontravam na parte superior. Este fato possivelmente é explicado pela infiltração de água proveniente de chuvas ou orvalho sobre os fardos que permaneciam sob constante exposição ao ambiente. E esta umidade externa, em associação à condensação de umidade interna ao fardo, garantiria condições de desenvolvimento fúngico na interface lona plástica e fardo.

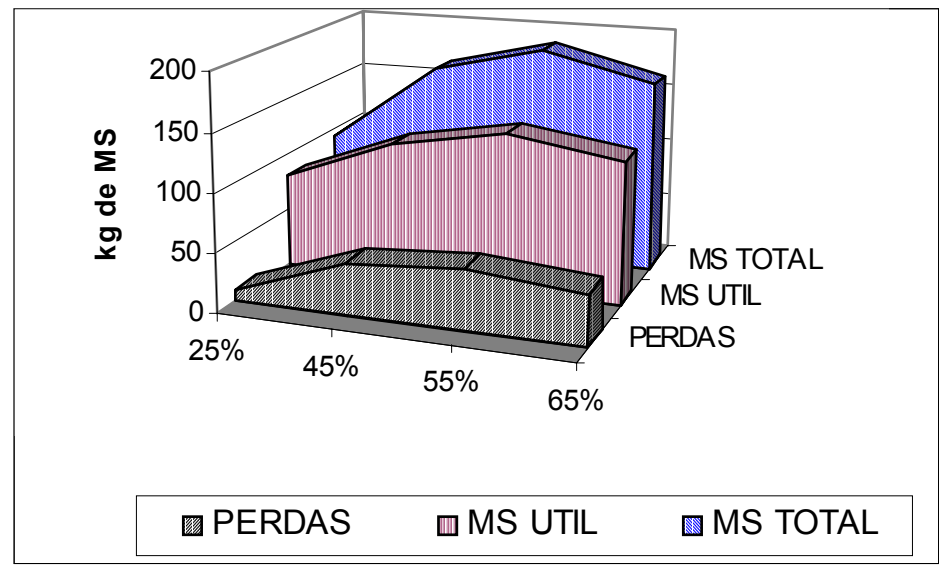

Figura 3 - Quantidade (kg) de matéria seca útil, perdida e total contida nos fardos não tratados com inoculante bacteriano-enzimático sob diferentes concentrações de MS.

De modo geral, as silagens tratadas com aditivos, apresentaram maiores problemas quanto a estabilidade aeróbica, exceto para o tratamento com 45\% MS, embora não seja confirmada pela análise estatística devido ao elevado coeficiente de variação $(55,8 \%)$. As silagens que continham menor teor de matéria seca (25SA e 25CA), mostraram maior eficiência para este parâmetro, podendo este efeito ser atribuído ao padrão de fermentação acética, próprio de silagens mais úmidas.

De acordo com Lambert \& Stratford (1999) a característica de proteção, através da presença de ácido acético, tem origem não pela morte do microrganismo, mas sim pela 
inibição do crescimento, principalmente na fase de colonização. A prevenção mostra-se efetiva em pH baixo, em que há aumento da concentração de ácidos fracos não dissociados. A inibição por ácidos fracos envolve rápida difusão de moléculas não dissociadas através da membrana plasmática. A dissociação destas moléculas, dentro da célula promove liberação de prótons, acidifica o citoplasma e prejudica o crescimento microbiano. Esta informação tem sido confirmada, pela nova tendência, de se produzir comercialmente cepas de bactérias heteroláticas produtoras de ácido lático e acético, afim de se diminuir perdas após abertura silo (Driehuis et al., 1999 e Driehuis et al., 2000).

Segundo Demarchi (2002) os inoculantes tradicionais promovem a formação de ácido lático, ideal para o rápido abaixamento do $\mathrm{pH}$ do silo e, conseqüente, estabilização, com perdas reduzidas. Porém, uma vez que o silo é aberto para consumo, o ácido lático pouco ajuda na preservação do material ao se disponibilizar como substrato para leveduras. O ácido acético, embora mais fraco do que o ácido lático e, portanto, não tão eficiente para garantir boa fermentação, acaba sendo mais eficiente do que o lático nesta etapa final do processo.

Castro et al. (2001a) estudando o perfil microbiológico das mesmas silagens de capim Tifton 85 sob efeito de emurchecimento e de inoculante bacteriano-enzimático, verificaram redução na atividade de água, e elevação no $\mathrm{pH}$ e na condutividade elétrica com o aumento da concentração de matéria seca. O incremento de matéria seca restringiu o crescimento bacteriano devido à redução da água livre, disponível no alimento. A presença do aditivo alterou a composição microbiológica das silagens, promovendo redução na contagem de microrganismos anaeróbicos e, respectivo aumento na população de aeróbicos, sugerindo que estas observações poderiam comprometer a estabilidade aeróbica. Diante desta análise, a comparação do escore de contaminação fúngica e da proporção de perdas de MS apresentado na Tabela 4, só apresentou coerência para o tratamento 25SA, sugerindo que a avaliação subjetiva da incidência de fungos e leveduras, nos painéis de silagem, apresentariam baixa acurácia.

Uma opinião errônea comum é de que os fungos são responsáveis pela deterioração da silagem quando está exposta ao ar. Entretanto, são as leveduras as 
principais responsáveis pela deterioração aeróbica e o aquecimento da silagem. Quando exposta ao ar, a levedura metaboliza ácido lático, que resulta na elevação do $\mathrm{pH}$ da silagem, permitindo assim o crescimento de bactérias, e favorecendo a deterioração da massa ensilada. A compactação do silo e a remoção de quantidade suficiente de silagem durante o fornecimento, podem ajudar na prevenção da deterioração aeróbica (Kung Júnior, 2000).

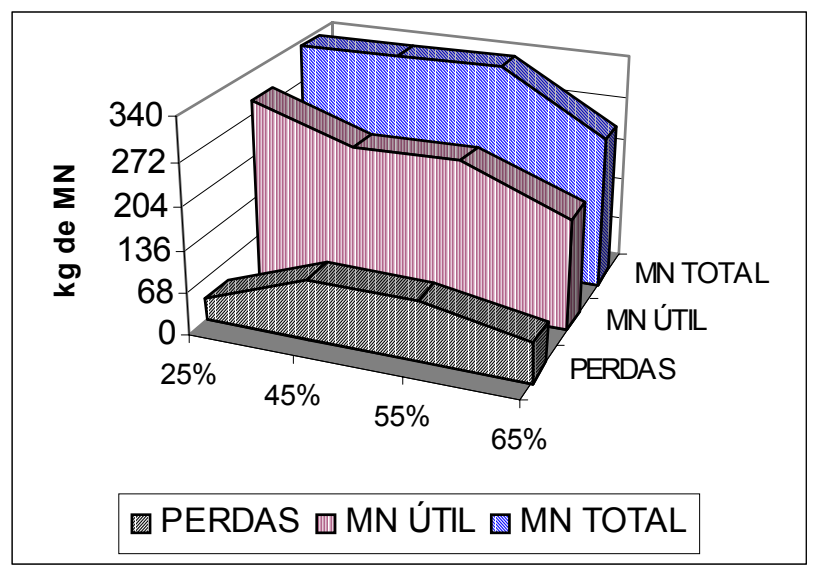

Figura 4 - Quantidade $(\mathrm{kg})$ de matéria natural útil, perdida e total contida nos fardos não tratados com inoculante bacteriano-enzimático sob diferentes concentrações de MS.

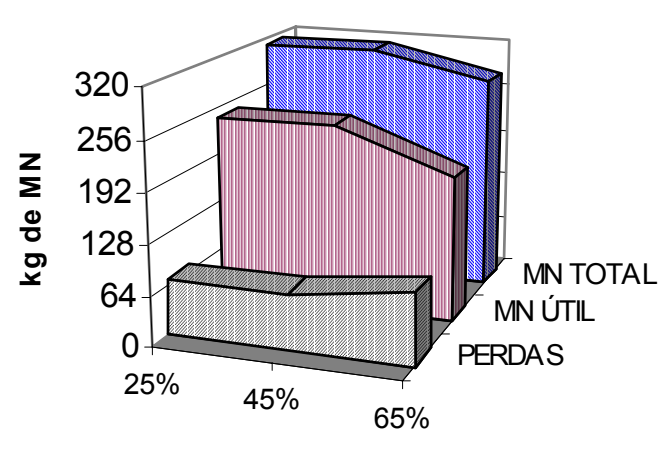

PERDAS $\square$ MN ÚTIL $\square$ MN TOTAL

Figura 5 - Quantidade $(\mathrm{kg})$ de matéria natural útil, perdida e total contida nos fardos tratados com inoculante bacteriano-enzimático sob diferentes concentrações de MS. 
É valido enfatizar, que este experimento foi conduzido na forma de quadrado latino, e cada unidade experimental foi representada por um animal, assim as silagens eram retiradas duas vezes ao dia para satisfazer às necessidades diárias de apenas um bovino. Esta informação contribui para explicar o comportamento das perdas das silagens após a abertura do silo. Em rebanhos comerciais, convivendo com maior taxa de consumo dos fardos decorrente de um maior número de animais que poderiam se alimentar simultaneamente, com silagem proveniente do mesmo fardo, haveria chance de uma menor exposição dos componentes da silagem à espoliação.

\subsection{Cinética ruminal}

\subsubsection{Consistência Ruminal}

A consistência ruminal, mensurada em função do tempo de ascensão do pêndulo imerso no rúmen, em segundos, não apresentou significância estatística pelo teste $\mathrm{F}$ $(\mathrm{P}=0,86)$. Portanto, pode-se considerar que a média dos tratamentos apresentados na Tabela 5, de 1365 segundos, é representativa para todos os tratamentos. Porém, a velocidade do pêndulo, avaliada em centímetros por segundos, apresentou alterações para os diferentes tratamentos estudados.

A velocidade de percurso apresentou tendência quadrática $(\mathrm{P}=0,11)$ em relação a concentração de matéria seca da silagem, havendo aumento da velocidade de percurso nas silagens com concentração de matéria seca extremas. O comportamento deste parâmetro não foi constante $(\mathrm{P}=0,03)$ para as silagens inoculadas e sem inoculante nos diversos teores de MS de silagens avaliadas. Os elevados coeficientes de variação também encontrados na Tabela 5 para as variáveis tempo de ascensão e velocidade de percurso podem ser explicados, em parte, pelo pequeno número de amostragens realizadas em cada período experimental e por diferenças individuais de comportamento ingestivo dos animais, mesmo que não tenham sido constatadas diferenças significativas pelo teste $\mathrm{F}$, para as variáveis período e animal no modelo de análise de variância. O delineamento empregado, em quadrados latinos, diluiu a margem de erro experimental, 
Tabela 5. Médias dos quadrados mínimos para variáveis de cinética ruminal observadas em bovinos e caracterização física de

\begin{tabular}{|c|c|c|c|c|c|c|c|c|c|c|c|c|c|}
\hline \multirow[t]{2}{*}{ Variável } & \multicolumn{3}{|c|}{ Com Aditivo } & \multicolumn{4}{|c|}{ Sem Aditivo } & \multirow[t]{2}{*}{$\mathrm{CV}$} & \multicolumn{5}{|c|}{ Contrastes $^{1}$} \\
\hline & 25 & 45 & 65 & 25 & 45 & 55 & 65 & & $\mathbf{L}$ & $\mathbf{Q}$ & AD & $\mathbf{L} * \mathbf{A D}$ & $\mathbf{Q}^{*} \mathbf{A D}$ \\
\hline \multicolumn{14}{|l|}{ Consistência ruminal } \\
\hline $\begin{array}{l}\text { Tempo de ascensão } \\
\quad \text { (seg.) }\end{array}$ & $1192^{\mathrm{a}}$ & $1379^{\mathrm{a}}$ & $934^{\mathrm{a}}$ & $1166^{\mathrm{a}}$ & $1338^{\mathrm{a}}$ & $1391^{\mathrm{a}}$ & $962^{\mathrm{a}}$ & 65 & 0,96 & 0,47 & 0,48 & 0,48 & 0,70 \\
\hline $\begin{array}{l}\text { Deslocamento } \\
\quad\left(\mathrm{cm} \mathrm{seg}^{-1}\right)\end{array}$ & $0,07^{\mathrm{b}}$ & $0,05^{\mathrm{b}}$ & $0,14^{\mathrm{a}}$ & $0,06^{\mathrm{b}}$ & $0,04^{\mathrm{b}}$ & $0,04^{\mathrm{b}}$ & $0,06^{\mathrm{b}}$ & 87 & 0,29 & 0,11 & 0,19 & 0,03 & 0,16 \\
\hline Taxa de passagem & & & & & & & & & & & & & \\
\hline Sólidos $\left(\%\right.$ hora $\left.^{-1}\right)$ & $3,52^{\mathrm{a}}$ & $2,20^{\mathrm{a}}$ & $3,64^{\mathrm{a}}$ & $2,84^{\mathrm{a}}$ & $3,21^{\mathrm{a}}$ & $3,20^{\mathrm{a}}$ & $2,81^{\mathrm{a}}$ & 33 & 0,57 & 0,12 & 0,48 & 0,20 & 0,16 \\
\hline Líquidos $\left(\%\right.$ hora $\left.^{-1}\right)$ & $3,77^{\mathrm{a}}$ & $3,55^{\mathrm{a}}$ & $4,57^{\mathrm{a}}$ & $3,76^{\mathrm{a}}$ & $5,25^{\mathrm{a}}$ & $5,15^{\mathrm{a}}$ & $4,96^{\mathrm{a}}$ & 42 & 0,14 & 0,89 & 0,54 & 0,69 & 0,12 \\
\hline \multicolumn{14}{|c|}{ Estratificação de partículas } \\
\hline \multicolumn{14}{|l|}{ Forragem oferecida } \\
\hline$<0,79 \mathrm{~cm}, \%$ & $0,53^{\mathrm{ab}}$ & $0,37^{\mathrm{b}}$ & $0,45^{\mathrm{ab}}$ & $0,40^{\mathrm{ab}}$ & $0,24^{\mathrm{b}}$ & $0,47^{\mathrm{ab}}$ & $0,67^{\mathrm{a}}$ & 54,6 & 0,05 & 0,04 & 0,14 & 0,24 & 0,67 \\
\hline $0,79-1,8 \mathrm{~cm}, \%$ & $1,87^{\mathrm{a}}$ & $1,10^{\mathrm{b}}$ & $1,17^{\mathrm{b}}$ & $1,34^{\mathrm{ab}}$ & $0,96^{\mathrm{b}}$ & $1,23^{\mathrm{b}}$ & $1,74^{\mathrm{a}}$ & 38,6 & 0,12 & 0,02 & 0,13 & 0,27 & 0,83 \\
\hline$>1,8 \mathrm{~cm}, \%$ & $97,6^{\mathrm{b}}$ & $98,5^{\mathrm{a}}$ & $98,4^{\mathrm{a}}$ & $98,3^{\mathrm{ab}}$ & $98,8^{\mathrm{a}}$ & $98,3^{\mathrm{ab}}$ & $97,6^{\mathrm{b}}$ & 0,7 & 0,01 & 0,47 & 0,50 & 0,02 & 0,03 \\
\hline Ração recusada & & & & & & & & & & & & & \\
\hline$<0,79 \mathrm{~cm}, \%$ & $5,62^{\mathrm{a}}$ & $11,0^{\mathrm{a}}$ & $10,8^{\mathrm{a}}$ & $7,46^{\mathrm{a}}$ & $9,01^{\mathrm{a}}$ & $21,2^{\mathrm{a}}$ & $15,7^{\mathrm{a}}$ & 123 & 0,18 & 0,83 & 0,53 & 0,40 & 0,85 \\
\hline $0,79-1,8 \mathrm{~cm}, \%$ & $5,85^{\mathrm{a}}$ & $4,80^{\mathrm{a}}$ & $6,75^{\mathrm{a}}$ & $6,11^{\mathrm{a}}$ & $6,74^{\mathrm{a}}$ & $4,17^{\mathrm{a}}$ & $5,73^{\mathrm{a}}$ & 67,2 & 0,77 & 0,98 & 0,28 & 0,54 & 0,87 \\
\hline$>1,8 \mathrm{~cm}, \%$ & $88,5^{\mathrm{a}}$ & $84,2^{\mathrm{a}}$ & $82,4^{\mathrm{a}}$ & $86,4^{\mathrm{a}}$ & $84,3^{\mathrm{a}}$ & $74,7^{\mathrm{a}}$ & $78,6^{\mathrm{a}}$ & 20,5 & 0,24 & 0,85 & 0,76 & 0,53 & 0,83 \\
\hline
\end{tabular}

${ }^{1}$ Contrastes =L: matéria seca efeito linear; Q: matéria seca efeito quadrática; AD: aditivo; L*AD: interação matéria seca linear e aditivo; Q*AD: interação matéria seca quadrática e aditivo. 
ao longo do experimento. Contudo, pressupondo-se o consumo de matéria seca ad libitum e a falta de homogeneidade na profundidade do rúmen entre os bois, estas variáveis poderiam causar grande impacto no tempo de ascensão do pêndulo e na velocidade de deslocamento.

A consistência ruminal de quatro novilhos canulados no rúmen, foi mensurada, após duas horas do fornecimento de alimentos pela manhã e ao entardecer Welch (1982). O tempo necessário para o peso ascender da parte ventral do rúmen até a porção dorsal foi considerada como indicativo da consistência ruminal. Um longo tempo de ascensão, pode ser associado com sólida quantidade de digesta fibrosa, e um curto período indicando uma camada superficial de menor resistência. Segundo Welch (1982) dietas baseadas em feno produziram denso conteúdo ruminal e maior tempo de ascensão do peso, 900 segundos pela manhã e 333 ao entardecer. As dietas à base de silagem de milho e, dieta com $80 \%$ de concentrado mais $20 \%$ de feno seguiram as respectivas ordens 201 e 89, 131 e 59 segundos, para os dois períodos de observação. Em outra dieta testada, a utilização de alfafa peletizada apresentou consistência ruminal baixa, com rápido tempo de ascensão do peso de 21 segundos para a mensuração matutina e 4 segundos para a vespertina, contudo algumas ascensões foram quase instantâneas. $\mathrm{O}$ tempo de ascensão decresce com aumento do tempo entre a alimentação e a amostragem no rúmen.

O aumento no consumo de alimentos foi testado, em outro experimento de Welch (1982), oferecendo os seguintes níveis de consumo de feno ad libitum de 40, 60, 80 e $100 \%$. A consistência ruminal foi mensurada duas vezes, com um intervalo de 13 horas e a unidade tempo usada foi o minuto, assim foram encontrados os seguintes tempos, para os respectivos níveis de consumo: $1,32 \pm 2,19$ e $0,23 \pm 0,35$ para $40 \%, 3,57 \pm 2,76$ e $2,16 \pm 2,30$ para $60 \%, 5,81 \pm 3,84$ e $5,38 \pm 0,84$ para $80 \%$ e $7,78 \pm 5,32$ e $5,42 \pm 4,16$ para $100 \%$ de feno. A variabilidade observada na estimativa destas médias, também revela a dificuldade de se identificar diferenças consistentes entre ingredientes, o que está de acordo com o que foi caracterizado na Tabela 5, no presente trabalho. Em resumo, as diferenças encontradas na mensuração da consistência ruminal, observadas em razão do tempo de ascensão do pêndulo, por Welch (1982) e não verificadas neste 
trabalho corroboram com as observações de Allen (1997). O referido autor afirma que a variação entre fontes similares de alimento tende a ser muito pequena, em comparação com outros alimentos. Este fato permitiria a possibilidade do valor da matéria orgânica, digestível no rúmen, poder ser usado genericamente, embora exista variação nas características do alimento, interações entre as dietas, animais e microrganismos ruminais, que afetam o tempo de resistência à digestão, no rúmen, e a atividade microbiológica. A variação de degradação ruminal entre alimentos tende a ser mais acentuada para fibras de fontes não oriundas de forragem, gerando diferenças no tempo de retenção no rúmen, com probabilidade de afetar a consistência ruminal.

Fitzgerald (1996) observou que cordeiros alimentados com silagem de azevém perene picado sob diferentes comprimentos de partícula, apresentaram declínio no consumo de 24,5 gramas de matéria seca para cada hora de aumento no tempo de retenção ruminal. Para cada centímetro reduzido em comprimento de partícula, houve aumento médio no consumo de silagem de 56 g MS, com ganho médio diário de 14 gramas, considerando um tempo de retenção ruminal reduzido a 1,53 horas. Na tentativa de se eliminar este efeito, uma das práticas de campo adotadas na ensilagem do capim Tifton 85, foi a regulagem da enfardadeira para que o tamanho das partículas se mantivesse dentro de um padrão homogêneo de corte, em torno de oito centímetros para todos os tratamentos. Devido a homogeneidade desta característica física nas silagens, assim como a utilização de um nível equivalente de concentrado em todas as rações, não se pode creditar influência do tamanho de partícula sob a consistência ruminal de qualquer tratamento.

Outros fatores alimentares que possivelmente causariam efeito neste parâmetro poderiam advir do consumo de matéria seca ou mais precisamente da ingestão de FDN; contudo, a avaliação destas estimativas, apresentadas na Tabela 7, não se mostraram significativas. Segundo Welch (1982) a digesta ruminal se constitui em uma massa estratificada com fibras longas e leves presentes no saco dorsal. Mudanças progressivas na flutuação da massa e a redução do tamanho médio de partícula, aumentam a gravidade específica das partículas e a passagem se torna máxima quando a gravidade específica atinge tamanho entre 1,10 a 1,20 $\mu \mathrm{m}$. Estes achados, sugerem que a 
combinação da digestão microbiana e da ruminação reduzem o tamanho da partícula, ao mesmo tempo hidratam a digesta com liberação de ar ou gases aprisionados na partícula. Com isto, é aumentada a chance da partícula obter acesso ao orifício retículo-omasal e aumentar a gravidade funcional específica no rúmen, próximo deste orifício.

A avaliação do consumo voluntário de alimentos, apresentado na Tabela 7, não foi caracterizada por diferenças significativas, porém houve um padrão de comportamento peculiar, que pode ser notado diariamente em função do oferecimento dos alimentos. Após o oferecimento matutino da refeição, os animais permaneciam ingerindo alimento, por um período aproximado de 3 horas, indistintamente a concentração de matéria seca das silagens. Como o início das atividades de mensuração se dava 4 horas após o fornecimento da ração, provavelmente, a atividade de ruminação exerceu pouca influência sobre o componente fibroso. Desta forma se existiram pequenas diferenças, provavelmente não foram detectadas.

Henriques et al. (2001b) estimaram o tempo de retenção ruminal da fase sólida em 66,2 e 92,6 horas e o tempo de retenção da fase líquida em 11,4 e 11,5 horas para silagens de capim elefante, tratadas ou não com ácido lático polimerizado (Acipim). Do mesmo modo foi estimado o tempo de retenção da fase sólida em 37,3 e 35,6 horas e 20,2 e 17,9 horas para fase líquida, em silagens de milho pelo modelo unicompartimental.

Castro et al. (2001b) verificando os parâmetros físico-químicos das mesmas silagem do capim Tifton 85, sob efeito do emurchecimento e de inoculante bacterianoenzimático, em função do tempo de armazenagem, encontraram uma queda mais acentuada no $\mathrm{pH}$ e também menores valores para este parâmetro em silagens inoculadas. Estes resultados sugerem a lise da membrana celular com extravasamento do conteúdo celular, consequentemente, levando à ocorrência de maior disponibilidade de substrato para o crescimento de microrganismos.

A associação destas duas idéias descritas anteriormente, pode possivelmente servir de explicação para a interação observada neste experimento. Partindo-se do princípio de que o tempo de retenção da fase sólida é maior que o tempo de retenção da fase líquida, para silagens que possuem menor concentração de matéria seca, e que esta relação se 
inverte, como também fica estreita com o acréscimo de matéria seca na silagem. O principal efeito da técnica de emurchecimento é o de elevar o teor de matéria seca, podendo explicar a primeira parte da associação, onde o inoculante bacterianoenzimático, na silagem de Tifton 85, proporcionou aumento da produção de ácidos orgânicos. Este efeito é similar ao do Acipim, que diminui o tempo de retenção de sólidos no rúmen e aumenta o tempo de retenção para a fase líquida.

\subsubsection{Taxa de passagem}

A taxa de passagem ruminal calculada para sólidos $(\mathrm{P}=0,39)$ e líquidos $(\mathrm{P}=0,44)$ não apresentou significância ao nível de $5 \%$ pelo teste $\mathrm{F}$, portanto as médias dos tratamentos apresentadas na Tabela 5 são equivalentes. Não ocorreu nenhum tipo de interação significativa para estes dois parâmetros.

Estes valores encontram-se próximos aos obtidos por Ribeiro et al. (2001c) que estimaram a taxa de passagem média de partículas 2,$78 ; 3,49 ; 3,16$ e $3,36 \% \mathrm{~h}^{-1} \mathrm{em}$ animais consumindo rações contendo feno de Tifton 85 aos 28, 35, 42 e 56 dias de idade, respectivamente, as quais não diferiram estatisticamente, encontrando-se como média geral $3,36 \% \mathrm{~h}^{-1}$.

Segundo Welch (1986) o tempo de permanência da fibra, no rúmen, e a taxa de passagem são importantes fatores que controlam o consumo, a digestibilidade e o metabolismo de proteínas. A retenção de uma fração de partículas pequenas, no interior do rúmen, se faz necessária para manter a atividade da população microbiana. A maior diferença na ingestão de ingredientes foi fundamentada na funcionalidade da gravidade específica, onde feno apresentando fibras longas ou moídas, tiveram uma gravidade específica inicial pouca funcional, sendo usualmente na ordem de 0,6 a 0,7. Entretanto, para concentrados a gravidade específica encontrada, foi em torno de 1,3 a 1,6.

Como as rações foram compostas basicamente pelas silagens de Tifton 85, e a proporção de concentrados baseada na matéria seca, as características físicas das rações se mantiveram constantes, assim, fatores independentes de sua composição química 
como: densidade energética, tamanho de partícula, solubilidade no rúmen e poder tampão, por exemplo, possivelmente não influenciaram a utilização do alimento.

O consumo de matéria seca também exerce influência sobre a taxa de passagem (Henriques et al., 2001b e Colucci et al., 1990). A verificação deste parâmetro na Tabela 7 não se mostrou significativa, portanto pode-se concluir que o consumo de matéria seca não deve ter exercido influência na estimativa da taxa de passagem.

\subsubsection{Tamanho de partícula}

A avaliação do tamanho das partículas das silagens pelo teste $\mathrm{F}$, através do percentual de material retido nas peneiras 1, 2 e 3, revelou diferença significativa ao nível de $5 \%$ de probabilidade, para a variável tratamento e período experimental, em relação ao conteúdo de partículas retido em todas as peneiras.

A avaliação do percentual de sobras das dietas retido nas peneiras 1, 2 e 3 não acusou diferença significativa pelo teste $\mathrm{F}$ ao nível de 5\% de probabilidade. Desta forma, pode-se dizer que o percentual médio encontrado na Tabela 5, para cada peneira, pode representar a quantidade de material retido para todos os tratamentos. Este fato sugere que o conjunto de peneiras utilizadas para a estratificação de partículas, não tenha sido suficientemente sensível para verificar alterações entre os tratamentos estudados.

Os dados obtidos para esta variável, no presente experimento, independente das diferenças estatísticas, sugerem que os percentuais das silagens e das sobras retidas na peneira 1 são elevados. Assim, no ato da agitação das peneiras, provavelmente não ocorreu desagregação suficiente para promover a passagem das mesmas pelos orifícios, sugerindo que o tamanho dos orifícios para avaliação de partículas em gramíneas tropicais perenes, deve ser revisto conforme já havia sido sugerido por Igarasi (2002).

Lima et al. (2001) através da análise da distribuição de partículas em silagem de milho, verificaram que a porcentagem de partículas maiores que 1,9 centímetros aumentou e, a porcentagem de partículas entre 8 e 19 centímetros diminuiu com a fiação das facas da ensiladora. Considerando as ensiladoras e as regulagens para o tamanho de corte, os equipamentos foram incapazes de proporcionar distribuição de partículas por 
tamanho e tamanho teórico médio de partículas adequados. Mais uma vez a caracterização física de silagens se mostrou problemática, neste caso apontando a necessidade de investimentos na indústria de fabricantes de equipamentos e colhedoras de forragem.

Crestana et al. (2001) verificaram que com o emurchecimento da forragem houve redução no teor de FDA e manutenção no teor de FDN, especialmente ao reduzir o tamanho médio de partículas. Aguiar et al. (2001) observaram que a redução no tamanho de partículas e a prática do emurchecimento foram mais eficientes na conservação das frações nitrogenadas, promovendo menores conversões destas frações em nitrogênio não protéico. Estas observações não puderam ser comprovadas no presente trabalho, pois, mesmo sabendo que houve diferenças significativas entre os tratamentos, a estratificação de partículas se mostrou muito homogênea. Da mesma forma, não puderam ser verificados os resultados descritos por Fitzgerald (1996), que observaram aumento progressivo no consumo e no desempenho de cordeiros alimentados com silagem de gramínea, quando o tamanho da partícula declinou de 32,4, 13, 9,1, 11,8 para 6,8 centímetros. O consumo foi de 572, 661, 750, 893 e 1129 ( $(21)$ g MS diárias para os

correspondentes ganhos de peso diário 3, 40, 53, 85 e $151( \pm 7,6)$ gramas dia ${ }^{-1}$. O aumento no consumo devido a precisão do corte de silagens, pôde ser associado ao curto tempo de retenção da digesta, no rúmen, ou pelo instinto de seleção de partículas da silagem.

\subsection{Comportamento do Animal}

O tempo médio de ingestão dos alimentos observado, neste experimento, durante 24 horas iniciais de cada período de coleta, não se mostrou diferente entre tratamentos, $(\mathrm{P}=0,20)$, podendo-se considerar que os novilhos da raça Nelore, em média, gastaram 324 minutos para fazerem suas refeições, conforme observado na Tabela 6 . 
Tabela 6. Médias dos quadrados mínimos para as variáveis de comportamento ingestivo de bovinos recebendo rações contendo silagens de capim Tifton 85 .

\begin{tabular}{|c|c|c|c|c|c|c|c|c|c|c|c|c|c|c|}
\hline \multirow[t]{2}{*}{ Variável } & \multicolumn{3}{|c|}{ Com Aditivo } & \multicolumn{4}{|c|}{ Sem Aditivo } & \multirow[t]{2}{*}{$\mathrm{CV}$} & \multirow[t]{2}{*}{ Média } & \multicolumn{5}{|c|}{ Contrastes $^{1}(\mathrm{P}<)$} \\
\hline & 25 & 45 & 65 & 25 & 45 & 55 & 65 & & & $\mathbf{L}$ & $\mathbf{Q}$ & AD & $L^{*} \mathbf{A D}$ & $\mathbf{Q} * \mathbf{A D}$ \\
\hline \multicolumn{15}{|l|}{ Ingestão de MS } \\
\hline Min $\operatorname{dia}^{-1}$ & $317^{\mathrm{a}}$ & $363^{\mathrm{a}}$ & $291^{\mathrm{a}}$ & $305^{\mathrm{a}}$ & $317^{\mathrm{a}}$ & $335^{\mathrm{a}}$ & $337^{\mathrm{a}}$ & 16 & 324 & 0,93 & 0,10 & 0,04 & 0,41 & 0,60 \\
\hline Min $\mathrm{kg}^{-1} \mathrm{MSI}^{2}$ & $47^{\mathrm{a}}$ & $52^{\mathrm{a}}$ & $41^{\mathrm{a}}$ & $45^{\mathrm{a}}$ & $46^{\mathrm{a}}$ & $49^{\mathrm{a}}$ & $50^{\mathrm{a}}$ & 20 & 47 & 0,80 & 0,27 & 0,07 & 0,37 & 0,87 \\
\hline Min $\mathrm{kg}^{-1} \mathrm{FDN}^{3}$ & $80^{\mathrm{a}}$ & $90^{\mathrm{a}}$ & $71^{\mathrm{a}}$ & $85^{\mathrm{a}}$ & $77^{\mathrm{a}}$ & $83^{\mathrm{a}}$ & $83^{\mathrm{a}}$ & 20 & 80 & 0,39 & 0,54 & 0,24 & 0,24 & 0,45 \\
\hline \multicolumn{15}{|l|}{ Ruminação } \\
\hline Min $\operatorname{dia}^{-1}$ & $514^{\mathrm{a}}$ & $524^{\mathrm{a}}$ & $499^{\mathrm{a}}$ & $543^{\mathrm{a}}$ & $530^{\mathrm{a}}$ & $515^{\mathrm{a}}$ & $498^{\mathrm{a}}$ & 6 & 518 & 0,08 & 0,35 & 0,51 & 0,05 & 0,97 \\
\hline Min $\mathrm{kg}^{-1} \mathrm{MSI}$ & $76^{\mathrm{a}}$ & $74^{\mathrm{a}}$ & $71^{\mathrm{a}}$ & $80^{\mathrm{a}}$ & $76^{\mathrm{a}}$ & $76^{\mathrm{a}}$ & $74^{\mathrm{a}}$ & 8 & 75 & 0,07 & 0,96 & 0,97 & 0,05 & 0,71 \\
\hline Min $\mathrm{kg}^{-1} \mathrm{FDN}$ & $125^{\mathrm{a}}$ & $126^{\mathrm{a}}$ & $122^{\mathrm{a}}$ & $141^{\mathrm{a}}$ & $130^{\mathrm{a}}$ & $127^{\mathrm{a}}$ & $120^{\mathrm{a}}$ & 8 & 126 & 0,06 & 0,86 & 0,16 & 0,02 & 0,79 \\
\hline \multicolumn{15}{|l|}{ Mastigação } \\
\hline Min $\operatorname{dia}^{-1}$ & $831^{\mathrm{a}}$ & $887^{\mathrm{a}}$ & $790^{\mathrm{a}}$ & $848^{\mathrm{a}}$ & $847^{\mathrm{a}}$ & $851^{\mathrm{a}}$ & $835^{\mathrm{a}}$ & 6 & 841 & 0,35 & 0,04 & 0,09 & 0,06 & 0,60 \\
\hline Min $\mathrm{kg}^{-1} \mathrm{MSI}$ & $123^{\mathrm{a}}$ & $126^{\mathrm{a}}$ & $114^{\mathrm{a}}$ & $124^{\mathrm{a}}$ & $122^{\mathrm{a}}$ & $125^{\mathrm{a}}$ & $124^{\mathrm{a}}$ & 10 & 123 & 0,29 & 0,41 & 0,19 & 0,12 & 0,95 \\
\hline Min $\mathrm{kg}^{-1} \mathrm{FDN}$ & $206^{\mathrm{a}}$ & $216^{\mathrm{a}}$ & $193^{\mathrm{a}}$ & $227^{\mathrm{a}}$ & $207^{\mathrm{a}}$ & $209^{\mathrm{a}}$ & $203^{\mathrm{a}}$ & 11 & 206 & 0,12 & 0,72 & 0,85 & 0,05 & 0,50 \\
\hline Ócio $\left(\min \operatorname{dia}^{-1}\right)$ & $589^{\mathrm{a}}$ & $530^{\mathrm{a}}$ & $613^{\mathrm{a}}$ & $560^{\mathrm{a}}$ & $558^{\mathrm{a}}$ & $549^{\mathrm{a}}$ & $571^{\mathrm{a}}$ & 9 & 567 & 0,74 & 0,05 & 0,20 & 0,02 & 0,75 \\
\hline $\begin{array}{l}\text { Ingestão de água } \\
\left(\mathrm{min}^{\left.-1 a^{-1}\right)}\right.\end{array}$ & $20^{\mathrm{a}}$ & $23^{\mathrm{a}}$ & $37^{\mathrm{a}}$ & $32^{\mathrm{a}}$ & $35^{\mathrm{a}}$ & $40^{\mathrm{a}}$ & $34^{\mathrm{a}}$ & 53 & 32 & 0,06 & 0,54 & 0,18 & 0,25 & 0,50 \\
\hline
\end{tabular}


A análise pelo teste $\mathrm{F}$ ao nível de $5 \%$ de probabilidade também não acusou diferença entre os tratamentos para os tempos médios de ruminação $(\mathrm{P}=0,09)$, ócio $(\mathrm{P}=0,09)$, mastigação $(\mathrm{P}=0,08)$ e ingestão de água $(\mathrm{P}=0,26)$ expressos em minutos. Logo, pode se considerar que as médias de 517 minutos dispensados para ruminação, 567 minutos em ócio, 841 minutos para mastigação e 31 minutos para ingestão de água, encontradas na Tabela 6, representam os tempos despendidos no exercício de cada atividade diária para todos os tratamentos. O coeficiente de variação para a ingestão de água se mostrou elevado 53,0\%, devido a uma ampla variação individual no consumo de água, mas à semelhança às demais variáveis seu comportamento esteve dentro de uma amplitude aceitável.

$\mathrm{O}$ tempo de ingestão apresentou efeito quanto ao uso de aditivo $(\mathrm{P}<0,05)$. A comparação das médias sugere aumento do tempo de ingestão para os tratamentos que receberam aditivos. $\mathrm{O}$ tempo de mastigação apresentou interação quadrática com o teor de matéria seca $(\mathrm{P}<0,05)$, sugerindo aumento no tempo de mastigação para silagens com teor de matéria seca em torno de $45-50 \%$.

O tempo em ócio observado para os animais apresentou efeito quadrático com o teor de matéria seca $(\mathrm{P}<0,05)$, e a análise das médias sugere um maior tempo em ócio para os tratamentos que estão nos dois extremos, estando de acordo com a tendência observada para o tempo de mastigação. $\mathrm{O}$ aumento do tempo em ócio para os tratamentos que receberam aditivos foi constatado, a medida que houve aumento da concentração de matéria seca. Adicionalmente, o teste $\mathrm{F}$ não acusou nenhuma forma de interação para os tempos de ruminação e de ingestão de água.

Valores próximos foram encontrados por Metz ${ }^{1}$ citado por Albright \& Arave (1997) observando vacas recebendo alimentos ad libitum onde, a duração do período de alimentação diário, apresentou variação de 148 a 392 minutos, com média de 330 minutos, e esta variabilidade não foi associada com o comportamento de consumo ou com o peso corporal dessas vacas. A ruminação diária abrangeu um período de 464 a 579 minutos, com média de 551 minutos, o número de ciclos de ruminação esteve em

\footnotetext{
${ }^{1}$ METZ, J.H.M. Time patterns of feeding and rumination in domestic cattle. Wageningen, Netherlands Meded Landbouwhogesch. PhD dissertation, NL 75-12, 1974.
} 
torno 10,8 a 16,9, com média de 14,0. O número de refeições foi mais frequente no início e ao final do dia, e quando mantidas em salas providas de iluminação contínua, as vacas alimentaram-se por 16 horas. O consumo de alimentos diários foi em média 14,7 $\mathrm{kg}(10,3$ a 18,5 kg). O número de refeições variou de 5,9 a 11,4 entre as vacas.

Fuller $^{2}$ citado por Albright \& Arave (1997) observou que aumento da concentração de FDN resultou em aumento quadrático na ruminação e no tempo total de mastigação para vacas leiteiras. Os valores encontrados para as respectivas taxas foram de 44,0 e 55,8 minutos dia $^{-1}$ com aumento de 26\% do FDN dietético, 403 e 651 minutos dia $^{-1}$ com aumento de $30 \%$ do FDN dietético e, 414 e 674 minutos dia ${ }^{-1}$ com aumento de $34 \%$ do FDN dietético. O consumo de feno gerou um aumento na produção de leite em $0,7 \mathrm{~kg} \mathrm{dia}^{-1}$, mas não determinou alterações nos tempos médios diários de ruminação, de mastigação, e ruminação diária por unidade de FDN consumido.

$\mathrm{O}$ teste $\mathrm{F}$ ao nível de $5 \%$ de probabilidade não acusou diferença significativa entre os tratamentos para a taxa de ingestão de $\mathrm{MS}(\mathrm{P}=0,39)$, a taxa de ruminação de $\mathrm{MS}$ $(\mathrm{P}=0,26)$ e a taxa de mastigação de $\mathrm{MS}(\mathrm{P}=0,41)$ com base no consumo médio de matéria seca da dieta. Portanto, pode-se considerar que a média dos tratamentos de 47,1, 75,2 e 122,6 min $\mathrm{kg}^{-1}$ de matéria seca, encontrados na Tabela 6, representam as respectivas taxas de ingestão, ruminação e mastigação para todos os tratamentos. Não foi registrada nenhuma interação para as taxas de ingestão, ruminação e mastigação de matéria seca das dietas.

Rabelo et al. (2001) verificaram influência do processamento de bagaço de cana sobre o comportamento ingestivo de novilhos de corte alimentados com dieta a base deste volumoso. Foram registrados maiores tempos despendidos às atividades de ingestão 20, 20 e $23 \mathrm{~min} \mathrm{~kg}^{-1}$ de matéria seca, ruminação 32, 34 e $45 \mathrm{~min} \mathrm{~kg}^{-1}$ de matéria seca e mastigação 53, 55 e $68 \mathrm{~min} \mathrm{~kg}^{-1}$ de matéria seca, com a substituição do bagaço tratado sob pressão e vapor pelos níveis 5, 10, e 15\% de bagaço in natura, obtido por difusão.

\footnotetext{
${ }^{2}$ FULLER, J.M. Some physical and physiological activities of dairy cows under conditions of modern herd management. Durham:New Hampshire Agricultural Experiment Station Technology Bulletin, 1928. v35.
} 
Em um tratamento adicional à substituição de $5 \%$ do bagaço base por bagaço in natura obtido por moagem, apresentou maior consumo de matéria seca (10,2 kg de MS) e menor tempo despendido com a atividade de ingestão e ruminação 15 e 28 min kg $^{-1}$ de matéria seca, respectivamente.

Os valores observados no presente experimento discordam dos encontrados por Rabelo et al. (2001). Neste ensaio a dieta continha apenas $20 \%$ de concentrado enquanto no trabalho de Rabelo et al. (2001) a dieta foi constituída com 50\% das exigências em ingredientes concentrados. Além disso, o processamento industrial garante atributos particulares ao bagaço de cana processado, havendo também diferenças devido ao tamanho de partícula.

Não foi detectada diferença significativa pelo teste $\mathrm{F}$, ao nível de $5 \%$ de probabilidade, para a ingestão de FDN ingerido na dieta $(\mathrm{P}=0,81)$, havendo um consumo médio de 4,10 kg de FDN equivalente a 1,11\% do peso corpóreo. De acordo com dados de literatura o consumo máximo de FDN pode ser projetado para valores próximos de $1,2 \%$ do peso corpóreo. Valor este, alcançado para o tratamento 25CA. Isto leva a concluir que o teor da parede celular seja fator limitante em dietas formuladas com alto teor de FDN, e que aumentos no consumo de matéria seca só serão possíveis quando houver decréscimo na quantidade de FDN da dieta. O que pode ser confirmado por Pereira et al. (1997) estudando o efeito da baixa e alta concentração de fibra na dieta sobre o consumo de matéria seca, em que notaram menor consumo de matéria seca $2,70 \%$ contra $3,02 \%$ do peso corporal e taxa de ganho de peso 0,78 contra $1,02 \mathrm{~kg} \mathrm{dia}^{-1}$ para rações com alta e baixa fibra, respectivamente. A limitação promovida pelo enchimento do rúmen-retículo e o maior tempo de retenção ruminal, são normalmente observados em dietas com altos teores de FDN. A ingestão de FDN apresentou diferenças significativas com relação ao nível de fibra, denotando maior consumo para a dieta de maior percentual de FDN, 3,45 contra 4,55 $\mathrm{kg} \mathrm{dia}^{-1}$.

No presente trabalho, não foram detectadas interações para as quantidades do FDN dietético expresso em porcentagem do peso corpóreo ou em quilos consumidos, conforme observações contidas nas Tabelas 6 e 7. 
Resultados inferiores aos observados neste trabalho foram reportados por Ribeiro et al. (2001b), que encontraram resposta quadrática ao consumo de FDN de feno em função da idade de crescimento da planta. Foram estimados consumos máximos de 3,4 $\mathrm{kg} \mathrm{dia}{ }^{-1}, 0,98 \%$ PV e 42,1 g/ $\mathrm{kg}^{0,75}$, em dietas contento feno com 41,5, 42,1 e 42,3 dias de crescimento, o que pode ser justificado pela similaridade no teor de FDN entre as rações testadas. Os maiores consumos de FDN em porcentagem de peso corporal encontrados na Tabela 7, deste trabalho, sugerem que comparativamente aos relatos de Ribeiro et al. (2001b), foram possivelmente resultantes da ocorrência de algum nível de substituição exercido pelo concentrado que representa $40 \%$ da ração.

Em relação a afirmação anterior, Pereira \& Armentano (1997) avaliando a digestibilidade aparente de dietas, variando quanto ao teor e origem do FDN, em um rebanho de 73 vacas, concluíram que o aumento no conteúdo de FDN diminuiu a digestibilidade de matéria orgânica, mas não afetou o consumo de matéria orgânica digestível. O consumo máximo observado, com o maior conteúdo de FDN e a similaridade no consumo de energia sugerem que a demanda energética determinou o nível de consumo em dietas com baixo teor de FDN, proveniente de forragem. Portanto, a origem do FDN deve ser considerada quando este é utilizado para previsão de consumo.

O teste $\mathrm{F}$ ao nível de $5 \%$ de probabilidade não acusou diferença significativa entre os tratamentos para a taxa de ingestão de $\operatorname{FDN}(\mathrm{P}=0,55)$, taxa de ruminação de FDN $(\mathrm{P}=0,06)$ e a taxa de mastigação de $\mathrm{FDN}(\mathrm{P}=0,31)$, com base no consumo médio de matéria seca da dieta. Portanto, pode-se considerar que a média dos tratamentos de 81,3, 127 e $208 \mathrm{~min} \mathrm{~kg}^{-1}$ de MS relatados na Tabela 6 representam as respectivas taxas médias de ingestão, ruminação e mastigação para todos os tratamentos. Não foi registrada nenhuma interação para as taxas de ingestão e mastigação de FDN das dietas. A taxa de ruminação de FDN apresentou interação linear entre o teor de matéria seca e a presença de aditivo $(\mathrm{P}<0,05)$, sugerindo queda da taxa de mastigação de FDN, com o aumento da concentração de matéria seca, para silagens tratadas com aditivo.

Segundo Allen (1997) a concentração da fibra (FDN e FDA) no alimento e o tamanho de partículas se relacionam positivamente $(\mathrm{P}<0,01)$ com o tempo total de 
mastigação, explicando uma variação de 26 a 32\%. A concentração de FDN e o percentual de forragem na dieta podem também se relacionar positivamente $(\mathrm{P}<0,01)$ com o tempo total de mastigação, respondendo por 10 a $20 \%$ de variação. O tamanho de partícula no momento da ceifa, o tipo de forragem (gramínea, leguminosa ou ambas em mistura), e o consumo de matéria seca não apresentaram correlação satisfatória com o tempo total de mastigação $(\mathrm{P}<0,05)$. Embora o tamanho de partícula não se relacione bem com o tempo total de mastigação, em alguns experimentos, pôde-se identificar a correlação. O tempo total de mastigação mostrou ser independente da variação no consumo de matéria seca (14,5 a 26,3 $\left.\mathrm{kg} \mathrm{dia}^{-1}\right)$, embora este consumo de matéria seca apresente relação positiva com o comportamento ingestivo em alguns experimentos.

Outra característica que deve ser abordada neste contexto, se refere à cronologia das atividades diárias. Após a oferta matutina de alimentos, representada por $60 \%$ da ração, pôde-se notar um período de alimentação em torno de três horas sem interrupção para todos os animais, seguido por um período de \pm 30 minutos em que os bois permaneceram em ócio. A partir deste horário, longos períodos de ruminação passaram a ser alternados com períodos de ócio, onde breves períodos de ingestão de alimentos e água também puderam ser constatados. Após o oferecimento da segunda refeição às 19:00 horas a freqüência da alimentação noturna se fez constante por aproximadamente uma hora depois deste horário, após a qual, a sucessão de eventos observados durante o dia se repetiu.

O levantamento das atividades diárias, proposto neste trabalho sugere que a concentração de matéria seca pelo uso da técnica de emurchecimento associada ou não ao uso de inoculante bacteriano-enzimático, na ensilagem de Tifton 85, não causou mudanças severas no comportamento ingestivo de novilhos Nelore e o provável controlador de consumo das dietas testadas, foi a concentração de FDN da silagem. Esta hipótese pode ser sustentada pelo pressuposto de que a maior parte do FDN dietético foi oriundo da forragem, o consumo de FDN para todas as dietas foi similar, podendo-se afirmar que a representatividade do concentrado das dietas, como moderador de consumo, foi pouco expressiva. 


\subsection{Ingestão de Matéria Seca}

$\mathrm{O}$ consumo de matéria seca das dietas não diferiu entre os tratamentos pelo teste $\mathrm{F}$ $(\mathrm{P}=0,95)$, desta maneira pode-se concluir que a média de consumo de 6,95 quilos de matéria seca da dieta representa o consumo médio de todos os tratamentos. O consumo de matéria seca da dieta expresso em percentual do peso corpóreo também não apresentou diferença significativa pelo teste $\mathrm{F}(\mathrm{P}=0,91)$. Assim, pode-se considerar que a média de consumo dos tratamentos encontrada na Tabela 7 de 1,88\% do peso corpóreo, também representa o consumo médio dos tratamentos. Os dados experimentais relatados por Erdman (1993), sugerem o declínio de uma unidade percentual em consumo, para o decréscimo de cada unidade percentual no conteúdo de matéria seca, fato que não foi observado no presente experimento. Aparentemente, a umidade das silagens não influencia o consumo voluntário diretamente, mas pela alteração do padrão de fermentação que possa ocorrer no interior do silo, incluindo degradação de proteínas e formação de vários ácidos orgânicos que passam a reduzir o consumo.

Resultados inferiores foram obtidos por Ribeiro et al. (2001b) que observaram comportamentos quadráticos dos consumos de matéria seca e orgânica de feno $\left(\mathrm{kg} \mathrm{dia}^{-1}\right.$, $\% \mathrm{PV}$ e $\mathrm{g} / \mathrm{kg}^{0,75}$ ), em função da idade de plantas forrageiras, exceto para o consumo de matéria orgânica (\%PV), que apresentou media de 1,53\% do peso corpóreo. Estimaramse consumos máximos MS de 5,81 $\mathrm{kg} \mathrm{dia}^{-1}, 1,67 \% \mathrm{PV}$ e $72 \mathrm{~g} / \mathrm{kg}^{0,75}$, quando as rações continham feno de Tifton 85 obtidos aos 40,6; 41,3; e 41,2 dias de rebrota, respectivamente. E o máximo consumo de matéria orgânica $5,51 \mathrm{~kg} \mathrm{dia}^{-1}$ e $68,39 \mathrm{~g} / \mathrm{kg}^{0,75}$ foi observado quando as rações continham feno de 40,6 e 41,1 dias, respectivamente. Contudo, advertiram que os consumos de matéria seca e matéria orgânica estiveram aquém dos esperados, provavelmente, devido ao estresse provocado nos animais pela metodologia de coletas realizadas, nesse tipo de experimento.

Os valores de NDT das silagens estimados de acordo com o NRC - gado de leite (2001) através da equação de Weiss modificada e apresentados na Tabela 10, estão de acordo com os valores apontados por Peixoto (1992) para silagens entre 4 e 10\% para proteína bruta e 50 a $65 \%$ para o NDT. 
Tabela 7. Médias dos quadrados mínimos para o consumo de matéria seca e ingestão de FDN observado em bovinos recebendo rações contendo silagens de capim Tifton 85 .

\begin{tabular}{|c|c|c|c|c|c|c|c|c|c|c|c|c|c|}
\hline \multirow[t]{2}{*}{ Variáveis } & \multicolumn{3}{|c|}{ Com aditivo } & \multicolumn{4}{|c|}{ Sem aditivo } & \multirow[t]{2}{*}{ C.V } & \multicolumn{5}{|c|}{ Contraste $(\mathrm{P}<)$} \\
\hline & 25 & 45 & 65 & 25 & 45 & 55 & 65 & & $\mathbf{L}$ & $\mathbf{Q}$ & AD & $\mathbf{L} * \mathbf{A D}$ & $\mathbf{Q}^{*} \mathbf{A D}$ \\
\hline \multicolumn{14}{|l|}{ Ingestão de MS } \\
\hline $\mathrm{kg} \mathrm{MS} \mathrm{dia}^{-1}$ & $6,80^{\mathrm{a}}$ & $7,09^{\mathrm{a}}$ & $7,16^{\mathrm{a}}$ & $6,98^{\mathrm{a}}$ & $7,00^{\mathrm{a}}$ & $6,81^{\mathrm{a}}$ & $6,83^{\mathrm{a}}$ & 8,5 & 0,77 & 0,36 & 0,80 & 0,78 & 0,59 \\
\hline $\begin{array}{c}\mathrm{kg} \mathrm{MS} 100 \mathrm{~kg} \text { peso } \\
\text { corpóreo }\end{array}$ & $1,96^{\mathrm{a}}$ & $1,87^{\mathrm{a}}$ & $1,89^{\mathrm{a}}$ & $1,89^{\mathrm{a}}$ & $1,89^{\mathrm{a}}$ & $1,84^{\mathrm{a}}$ & $1,80^{\mathrm{a}}$ & 11,0 & 0,49 & 0,84 & 0,94 & 0,49 & 0,84 \\
\hline \multicolumn{14}{|l|}{ Ingestão FDN } \\
\hline FDN dieta & $60,2^{\mathrm{ab}}$ & $58,5^{\mathrm{bc}}$ & $59,5^{\mathrm{ab}}$ & $57,5^{\mathrm{c}}$ & $58,8^{\mathrm{bc}}$ & $59,5^{\mathrm{ab}}$ & $61,3^{\mathrm{a}}$ & 2,9 & 0,36 & 0,34 & 0,15 & 0,05 & 0,14 \\
\hline kg FDN dia ${ }^{-1}$ & $4,06^{\mathrm{a}}$ & $4,16^{\mathrm{a}}$ & $4,14^{\mathrm{a}}$ & $3,84^{\mathrm{a}}$ & $4,21^{\mathrm{a}}$ & $4,07^{\mathrm{a}}$ & $4,19^{\mathrm{a}}$ & 9,1 & 0,36 & 0,28 & 0,81 & 0,37 & 0,64 \\
\hline $\begin{array}{l}\mathrm{kg} \text { FDN } 100 \mathrm{~kg} \text { peso } \\
\text { corpóreo }\end{array}$ & $1,20^{\mathrm{a}}$ & $1,08^{\mathrm{a}}$ & $1,12^{\mathrm{a}}$ & $1,03^{\mathrm{a}}$ & $1,13^{\mathrm{a}}$ & $1,10^{\mathrm{a}}$ & $1,10^{\mathrm{a}}$ & 14,0 & 0,88 & 0,89 & 0,51 & 0,17 & 0,33 \\
\hline
\end{tabular}

${ }^{1}$ Contrastes = L: matéria seca efeito linear; Q: matéria seca efeito quadrática; AD: aditivo; L*AD: interação matéria seca linear e aditivo; Q*AD: interação matéria seca quadrática e aditivo. 
De acordo com Boin (s.d.), o primeiro fator que controla o consumo voluntário de matéria seca de bovinos em confinamento é o enchimento do trato digestivo, em especial do retículo-rúmen. Portanto, o consumo aumenta a medida em que aumenta a digestibilidade da ração. Isto ocorre até um valor energético de aproximadamente 2,5 Mcal de EM kg-1 MS ( $\pm 70 \%$ de NDT), decrescendo a seguir. O baixo valor encontrado para o NDT das silagens, influenciou o NDT das dietas, levantando a suspeita de que as modificações propostas por Weiss ao calculo de NDT, estejam subestimando os valores de digestibilidade ao se comparar com os valores de digestibilidade in vivo da MS, também apresentados na Tabela 10.

Segundo Lucci (1997) as silagens têm potencial de ingestão de apenas 61\% a 70\% das forragens originais; os fenos curados a campo de $78 \%$ a $80 \%$, os secos em galpões, de $85 \%$ a $87 \%$. Os melhores valores de potencial de ingestão de forragens conservadas são obtidos com feno seco artificialmente $(98 \%)$ e silagens tratadas com ácido fórmico (97\%). Quanto ao potencial de digestibilidade em forragens conservadas é de $88 \%$ a 94\% da digestão de forragens frescas, mas o feno artificialmente desidratado mantém 99\% deste valor. O consumo potencial de forragens nem sempre se mantém durante o processo de ensilagem. O principal fator desta redução é associado diretamente à alta umidade de gramíneas e leguminosas no momento da ceifa ou pelo uso inadequado da técnica do emurchecimento.

No presente experimento, o consumo não revelou comportamento linear ou quadrático, para a elevação da concentração de matéria seca, divergindo desta maneira da avaliação de 136 silagens conduzida por Steen et al. (1998), que verificaram aumento linear entre o consumo de matéria seca, com o aumento do teor de matéria seca $(\mathrm{P}<0,01)$.

Segundo Steen et al. (1998), a menor concentração de matéria seca nas silagens resultou em decréscimo no consumo de MS, e o maior teor de MS esteve associado com o consumo máximo, encontrado para concentração de $320 \mathrm{~g} \mathrm{~kg}^{-1}$. Neste trabalho, também foi encontrada relação linear positiva $(\mathrm{P}<0,05)$ para consumo, proteína bruta, $\mathrm{N}$ insolúvel, N-solúvel, N-protéico e solúvel, ambos expressos na MS e baseados na 
proporção do N-total. Entretanto, a relação quadrática comportou-se melhor para representar os efeitos com exceção para a fração $\mathrm{N}$ protéico menos solúvel.

As alterações na fração protéica, provocadas pela taxa de desidratação e pelo padrão de fermentação, também foram observadas no presente trabalho (Tabela 3) e indicam haver aumentos progressivos das frações N-FDN em detrimento da Fração NFDA e $B_{3}$, apesar da fração $\mathrm{N}$ total não ter apresentada variação significativa $(\mathrm{P}>0,05)$.

Frost et al. (1995) observaram um consumo médio $45 \%$ mais elevado para silagens emurchecidas, comparado a silagens que foram diretamente ensiladas, embora ao final do período experimental, a diferença entre as silagens não tenha sido significativa. $O$ aumento de consumo pode ser atribuído a melhor preservação e também pelo aumento na concentração de matéria seca per se. As silagens que sofreram ação do emurchecimento apresentaram digestibilidade superior às silagens convencionais $(\mathrm{P}<0,01)$.

$\mathrm{O}$ aumento médio de consumo em resposta ao emurchecimento, em muitos estudos, pode ser atribuído à manutenção das características originais da planta no período de armazenagem. Esta característica, possibilitou melhora de 16\% no consumo de matéria seca em comparação com a secagem artificial de azevém perene e, $41 \%$ em comparação com a silagem controle. $\mathrm{O}$ efeito mais positivo do emurchecimento sobre o consumo, foi observado ao se atingir a concentração final de matéria seca de $470 \mathrm{~g} \mathrm{~kg}^{-1}$. Com relação ao uso de aditivos, a magnitude de respostas positivas no desempenho animal pôde ser relacionada com o conteúdo de carboidratos solúveis na planta, no momento da ensilagem (Dawson et al., 1999).

Diferenças de consumo também não foram registradas por Souza et al. (2001) que avaliaram o consumo de nutrientes, ganho de peso e conversão alimentar de 24 novilhos, mestiços inteiros, com peso inicial de $360 \mathrm{~kg}$ recebendo rações com diferentes proporções de silagem de sorgo e silagem emurchecida, de capim Tifton 85, suplementadas com $40 \%$ de concentrado. Os consumos médios diários em $\mathrm{kg} \mathrm{dia}^{-1}$, de matéria seca, matéria orgânica, proteína bruta, extrato etéreo, e carboidratos totais não foram influenciados pelas rações, registrando-se valores de 9,46; 9,05; 1,20; 0,51 e 7,43 $\mathrm{kg}$, respectivamente. O consumo médio de matéria seca mais elevado observado nestas 
dietas, sugere que a proporção de concentrado e a concentração de nutrientes presentes na dieta, influenciaram a ingestão de alimentos (Castillo et al., 1997).

Keady \& Mayne (2001) encontraram diferenças no teor de matéria seca, no parâmetro de fermentação e no potencial de consumo de silagens de azevém perene sobre influência de diferentes técnicas de ensilagem. Esta diferença foi de 3,7 quilos de matéria seca para silagem emurchecida tratada com inoculante, quando comparada com silagem convencional. McAllister et al. (1998) verificou que a inoculação com Lactobacilus plantarum em conjunto Enterococcus faecium ou somente a inclusão de Lactobacilus plantarum, em silagem de alfafa, aumentou o consumo de matéria seca de novilhos, quando comparados com a silagem controle. Em média, a eficiência alimentar foi melhor para o uso dos inoculantes associados, quando comparado ao segundo tratamento, contudo, a silagem controle se posicionou entre os dois tratamentos.

Rodrigues et al. (2001c) não observaram alteração no consumo de matéria seca utilizando doze ovinos machos e castrados alimentados com silagem de capim elefante inoculada (Pioneer $1174^{\circledR}$ ) com bactérias ácido láticas $\left(423,5 \mathrm{~g} \mathrm{dia}^{-1}\right.$ ) em relação ao controle $\left(435,9 \mathrm{~g} \mathrm{dia}^{-1}\right)$. A baixa disponibilidade de energia e baixa concentração de proteína, da silagem, podem explicar o baixo consumo das silagens, que em média foi de 1,5\% do peso corpóreo. Da mesma forma, Rodrigues et al. (2001e), utilizando outro produto comercial (Sil-All ${ }^{\circledR}$ ) contendo inoculante bacteriano na ensilagem de sorgo, também não encontraram aumento significativo do consumo voluntário de oito ovinos, que em média foi de 1,7\% do peso corpóreo. Rodrigues et al. (2001b) avaliando o valor nutritivo da silagem de girassol inoculada com bactérias homoláticas em oito ovinos machos e castrados, não observaram efeito no consumo de matéria seca $\left(737,4 \mathrm{~g} \mathrm{dia}^{-1}\right)$ da silagem inoculada em relação ao controle $\left(775,7 \mathrm{~g} \mathrm{dia}^{-1}\right)$. Com o mesmo propósito e metodologia similar, Rodrigues et al. (2001d) adicionaram o mesmo produto comercial (Pioneer $1174^{\circledR}$ ) em silagem de milho mas este também não caracterizou efeito positivo sobre o consumo de matéria seca de ovinos, que em media foi de 2,2\% do peso corpóreo. Rodrigues et al. (2001a) em um outro experimento encontraram aumento significativo na ordem de $13,7 \%$ com a adição de outra marca comercial (Silobac) de 
inoculante em silagem de alfafa. Os ovinos consumiram 2,8\% de PV contra 2,5\% de seu controle.

Silagens de azevém perene tratadas com Lactobacilus plantarum ou ácido fórmico apresentaram significativo $(\mathrm{P}<0,05)$ aumento no consumo de matéria seca. $\mathrm{O}$ tratamento com inoculante aumentou o ganho de peso, e os aditivos apresentaram tendência aos aumentos do ganho na carcaça $(\mathrm{P}=0,14)$ (Keady \& Steen, 1995).

\subsection{Parâmetros Ruminais}

\subsection{1 pH}

Não foi detectada diferença significativa pelo teste $\mathrm{F}$ ao nível de $5 \%$ de probabilidade para os valores de $\mathrm{pH}$ ruminal em função da variável tratamento $(\mathrm{P}=0,81)$ e para a interação entre tratamento e tempo $(\mathrm{P}=0,99)$, portanto pode-se afirmar que o valor médio de $\mathrm{pH}(6,76)$ em função do tempo (Tabela 10) pode representar a média de todos os tratamentos ao longo do período experimental. $\mathrm{O}$ teste $\mathrm{F}$ acusou diferença para a variável tempo $(\mathrm{P}<0,01)$ havendo assim, alteração do valor de $\mathrm{pH}$ ao longo dos horários de coleta.

Os valores de $\mathrm{pH}$ encontrados nas Tabelas 8 e 9 estiveram sempre acima de 6,0. Segundo Lucci (1997), em geral, o pH estável no rúmen, varia entre 5,5 e 6,8 e é mantido nesta amplitude graças ao poder tamponante da saliva, e ao mecanismo de absorção de ácidos graxos. Quando o $\mathrm{pH}$ aumenta no interior do proventrículo, a absorção de ácidos orgânicos pelas paredes epiteliais é diminuída.

Somente a concentração FDN, na dieta, não pode ser relacionada com o $\mathrm{pH}$ ruminal, embora a concentração FDN seja relacionada com o tempo total de mastigação em rações completas a base de forragem. A relação positiva entre ambos é devido a porcentagem de matéria orgânica realmente digestível no rúmen, e não pelo $\mathrm{pH}$ ruminal, uma vez que o aumento da produção de ácidos pela fermentação é função do aumento da porcentagem de matéria orgânica, digestível no rúmen. O aumento da degradação ruminal é desejável para maximizar a produção de proteína microbiana e o consumo de 
Tabela 8. Médias dos quadrados mínimos para as variáveis ruminais observadas em bovinos recebendo rações contendo silagens de capim Tifton 85 .

\begin{tabular}{|c|c|c|c|c|c|c|c|c|c|c|}
\hline \multirow[t]{2}{*}{ Variáveis } & \multicolumn{3}{|c|}{ Com aditivo } & \multicolumn{4}{|c|}{ Sem aditivo } & \multirow{2}{*}{$\begin{array}{l}\text { Trat }^{1} \\
(\mathbf{P}<)\end{array}$} & \multirow{2}{*}{$\begin{array}{c}\text { Tempo }^{2} \\
(\mathbf{P}<)\end{array}$} & \multirow{2}{*}{$\begin{array}{c}\text { Trat**Tempo }^{3} \\
(\mathbf{P}<)\end{array}$} \\
\hline & 25 & 45 & 65 & 25 & 45 & 55 & 65 & & & \\
\hline \multicolumn{11}{|l|}{$\begin{array}{l}\text { Concentração de AGV } \\
(\mathrm{mM})\end{array}$} \\
\hline $\mathrm{C} 2$ & $94,84^{\mathrm{a}}$ & $94,09^{\mathrm{a}}$ & $99,71^{\mathrm{a}}$ & $100,05^{\mathrm{a}}$ & $99,18^{\mathrm{a}}$ & $100,71^{\mathrm{a}}$ & $94,67^{\mathrm{a}}$ & 0,96 & 0,57 & 0,34 \\
\hline $\mathrm{C} 3$ & $24,03^{\mathrm{a}}$ & $24,93^{\mathrm{a}}$ & $23,93^{\mathrm{a}}$ & $24,41^{\mathrm{a}}$ & $25,36^{\mathrm{a}}$ & $26,57^{\mathrm{a}}$ & $24,23^{\mathrm{a}}$ & 0,81 & 0,06 & 0,57 \\
\hline $\mathrm{C} 4$ & $13,86^{\mathrm{a}}$ & $13,46^{\mathrm{a}}$ & $13,65^{\mathrm{a}}$ & $13,37^{\mathrm{a}}$ & $13,96^{\mathrm{a}}$ & $14,07^{\mathrm{a}}$ & $12,96^{\mathrm{a}}$ & 0,97 & 0,01 & 0,59 \\
\hline CI4 & $1,37^{\mathrm{a}}$ & $1,32^{\mathrm{a}}$ & $1,17^{\mathrm{a}}$ & $1,62^{\mathrm{a}}$ & $1,34^{\mathrm{a}}$ & $1,41^{\mathrm{a}}$ & $1,25^{\mathrm{a}}$ & 0,48 & 0,03 & 0,75 \\
\hline $\mathrm{C} 5$ & $1,33^{\mathrm{a}}$ & $1,26^{\mathrm{a}}$ & $1,32^{\mathrm{a}}$ & $1,44^{\mathrm{a}}$ & $1,35^{\mathrm{a}}$ & $1,27^{\mathrm{a}}$ & $1,32^{\mathrm{a}}$ & 0,62 & 0,01 & 0,44 \\
\hline CI5 & $1,66^{\mathrm{a}}$ & $1,63^{\mathrm{a}}$ & $1,72^{\mathrm{a}}$ & $1,92^{\mathrm{a}}$ & $1,90^{\mathrm{a}}$ & $1,46^{\mathrm{a}}$ & $1,44^{\mathrm{a}}$ & 0,08 & 0,01 & 0,54 \\
\hline $\mathrm{C} 2 / \mathrm{C} 3$ & $4,22^{\mathrm{a}}$ & $3,95^{\mathrm{a}}$ & $4,23^{\mathrm{a}}$ & $4,26^{\mathrm{a}}$ & $4,37^{\mathrm{a}}$ & $3,98^{\mathrm{a}}$ & $4,05^{\mathrm{a}}$ & 0,72 & 0,16 & 0,73 \\
\hline TOTAL & $137,10^{\mathrm{a}}$ & $136,72^{\mathrm{a}}$ & $141,51^{\mathrm{a}}$ & $142,88^{\mathrm{a}}$ & $143,10^{\mathrm{a}}$ & $144,84^{\mathrm{a}}$ & $135,91^{\mathrm{a}}$ & 0,96 & 0,28 & 0,46 \\
\hline pH & $6,81^{\mathrm{a}}$ & $6,74^{\mathrm{a}}$ & $6,74^{\mathrm{a}}$ & $6,72^{\mathrm{a}}$ & $6,73^{\mathrm{a}}$ & $6,82^{\mathrm{a}}$ & $6,77^{\mathrm{a}}$ & 0,81 & 0,01 & 0,99 \\
\hline $\mathrm{N}$-amoniacal (mg dL $\left.{ }^{-1}\right)$ & $6,18^{\mathrm{a}}$ & $6,49^{\mathrm{a}}$ & $6,25^{\mathrm{a}}$ & $7,62^{\mathrm{a}}$ & $6,12^{\mathrm{a}}$ & $5,94^{\mathrm{a}}$ & $5,61^{\mathrm{a}}$ & 0,08 & 0,01 & 0,75 \\
\hline
\end{tabular}

\footnotetext{
${ }^{1}$ Teste $\mathrm{F}$ para o efeito de tratamento.

${ }^{2}$ Teste F para o efeito de tempo.

${ }^{3}$ Teste F para o efeito da interação tratamento*tempo.
} 
Tabela 9. Evolução temporal das média dos quadrados mínimos para as variáveis ruminais observadas em bovinos recebendo rações contendo silagens de capim Tifton 85 .

\begin{tabular}{|c|c|c|c|c|c|c|c|c|c|c|}
\hline \multirow{2}{*}{$\begin{array}{l}\text { Horário } \\
\text { de coleta }\end{array}$} & \multirow[t]{2}{*}{$\mathrm{C} 2$} & $\mathrm{C} 3$ & $\mathrm{C} 4$ & CI4 & $\mathrm{C} 5$ & CI5 & $\mathrm{C} 2 / \mathrm{C} 3$ & TOTAL & $\mathrm{pH}$ & \multirow[t]{2}{*}{$\begin{array}{c}\text { N-amoniacal } \\
\mathrm{mg} \mathrm{dL}^{-1}\end{array}$} \\
\hline & & \multicolumn{6}{|c|}{ Concentração média de ácidos graxos voláteis (mM) } & & & \\
\hline 0:00 & 93,02 & 23,79 & 12,33 & 1,33 & 0,96 & 1,49 & 4,30 & 135,80 & 6,78 & 3,80 \\
\hline 2:00 & 98,67 & 23,24 & 12,71 & 1,49 & 1,60 & 2,09 & 4,41 & 139,81 & 6,87 & 10,83 \\
\hline 4:00 & 95,51 & 24,10 & 13,62 & 1,49 & 1,60 & 1,97 & 4,13 & 139,31 & 6,79 & 9,53 \\
\hline $6: 00$ & 95,75 & 24,43 & 14,06 & 1,50 & 1,49 & 1,85 & 4,16 & 140,08 & 6,81 & 7,87 \\
\hline 8:00 & 99,06 & 25,04 & 14,30 & 1,54 & 1,33 & 1,61 & 4,05 & 142,86 & 6,80 & 5,05 \\
\hline $10: 00$ & 101,79 & 25,05 & 14,29 & 1,39 & 1,21 & 1,59 & 4,15 & 145,34 & 6,67 & 4,15 \\
\hline $12: 00$ & 92,43 & 23,44 & 12,61 & 1,35 & 1,17 & 1,43 & 4,13 & 132,42 & 6,90 & 3,68 \\
\hline $14: 00$ & 100,73 & 26,86 & 14,51 & 1,28 & 1,64 & 1,93 & 3,94 & 146,97 & 6,58 & 9,85 \\
\hline $16: 00$ & 102,31 & 27,33 & 14,61 & 1,43 & 1,53 & 1,79 & 4,00 & 149,23 & 6,69 & 7,04 \\
\hline $18: 00$ & 100,34 & 25,93 & 14,23 & 1,28 & 1,29 & 1,58 & 4,11 & 144,56 & 6,74 & 5,63 \\
\hline 20:00 & 93,03 & 24,99 & 13,32 & 1,21 & 1,11 & 1,44 & 4,18 & 135,18 & 6,75 & 4,38 \\
\hline $22: 00$ & 92,64 & 23,18 & 15,63 & 0,99 & 1,02 & 1,37 & 4,25 & 131,85 & 6,80 & 3,96 \\
\hline
\end{tabular}


energia, mas o aumento da produção de ácidos deve ser compensado pela necessidade de aumento do conteúdo FDN na dieta ou aumento da efetividade física FDN para manter o pH, com estimulação da secreção de tamponantes através da saliva, via mastigação (Allen, 1997).

Resultados inferiores foram registrados por Ribeiro et al. (2001c) que verificaram pH mínimo de 6,08, aproximadamente 6:00 horas após a alimentação com feno de Tifton 85, não havendo efeito da idade cronológica da planta sobre os valores de $\mathrm{pH}$ ruminal. Valores similares foram encontrados por Henriques et al. (1997a) verificando possíveis diferenças no $\mathrm{pH}$ do líquido ruminal de bovinos que receberam silagens de milho tratadas ou não com ácido lático polimerizado residual (Acipim), porém as silagens de capim elefante tratadas da mesma forma apresentaram $\mathrm{pH}$ superior às encontradas neste trabalho. Possivelmente as diferenças encontradas para este parâmetro, se deram pela fermentação restrita, oriunda da concentração de matéria seca e, possivelmente, pelas características do silo.

A concentração de íon hidrogênio também afeta as diferenças na constante de dissociação dos ácidos, com dez vezes mais intensidade para o ácido lático. Embora o grau de dissociação seja dependente do $\mathrm{pH}$, um $\mathrm{pH}$ ruminal pouco abaixo de 6,0, determina a diferença entre todos os ácidos fermentados. Porque, o ácido lático atinge sua completa dissociação enquanto os ácidos graxos voláteis são tampões a um pH mais elevado. O acúmulo de ácido lático ocorre quando o fluxo glicolítico é alto devido a alta intensidade de fermentação de hexoses por unidade de tempo, sendo típico durante o período de adaptação de dietas ricas em carboidratos não estruturais, levando facilmente a diminuição do $\mathrm{pH}$ ruminal. Embora a maioria dos íons hidrogênio seja removida do rúmen por absorção e passagem, as flutuações do $\mathrm{pH}$, são dependentes do aumento da taxa de absorção de AGVs, taxa de passagem de fluidos, fluxo de entrada de água no rúmen ou saída através da parede ruminal, do padrão da refeição e da taxa de degradação e passagem da matéria orgânica (Allen, 1997). 


\subsubsection{Evolução temporal da concentração do pH}

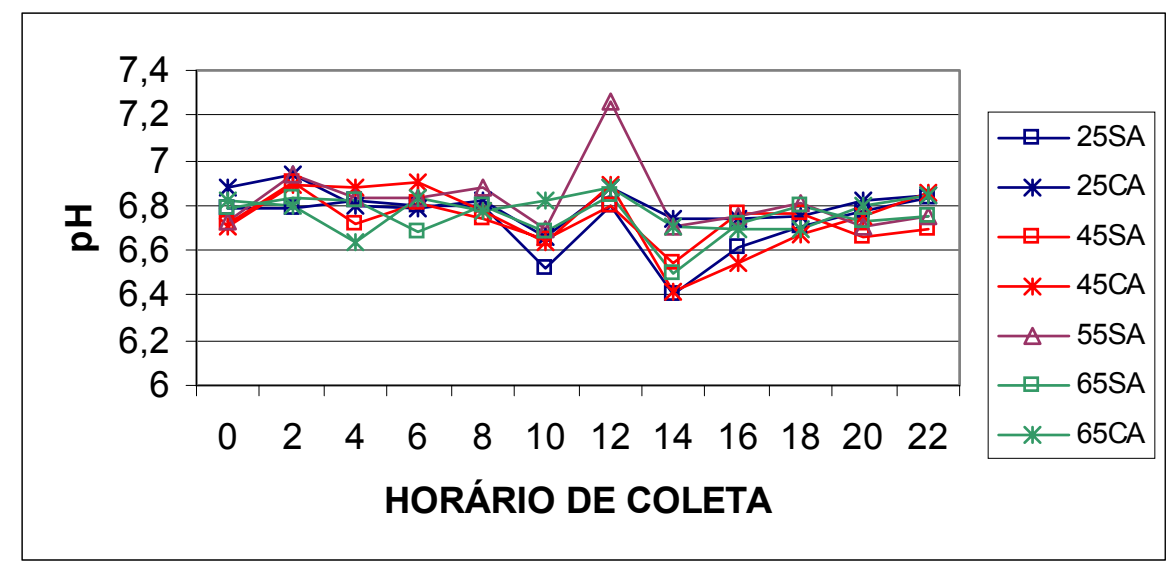

Figura 6 - Efeito das dietas experimentais sobre a evolução diária do $\mathrm{pH}$, no fluido ruminal.

Os efeitos dos horários de coleta sobre os valores de $\mathrm{pH}$ do fluido ruminal, estão apresentados na Figura 6, sendo importante lembrar que os animais foram alimentados duas vezes ao dia, às 7:00 e às 19:00 horas e que a evolução diária apresentada é iniciada (0h) a partir da primeira refeição diária (7:00). A variação do pH durante o dia seguiu um padrão de evolução normal onde os maiores valores de $\mathrm{pH}$ são observados anteriormente aos horários de alimentação. Os picos de baixa no pH do fluido ruminal ocorreram entre às 4:00 e 8:00 horas e por volta das 14:00 horas após alimentação, quando existiu grande concentração de ácidos orgânicos, provenientes da fermentação dos substratos pelos microorganismos, no fluido ruminal. As médias de $\mathrm{pH}$ ruminal dos tratamentos, se mostraram sempre superiores a 6,0, no decorrer do dia. Isto indica que as alterações nos parâmetros de fermentação ruminal impostos pelos tratamentos, não foram suficientemente expressivos a ponto de determinar redução significativa no $\mathrm{pH}$ ruminal, o que já era esperado pelo percentual de participação de volumosos na dieta. 


\subsection{2 Ácidos graxos voláteis}

A análise dos ácidos graxos voláteis é apresentada na seguinte seqüência: concentração média de ácido acético (C2), ácido propiônico (C3), ácido butírico (C4), ácido isobutírico (CI4), ácido valérico (C5) e ácido isovalérico (CI5). Foi também avaliada a proporção entre o ácido acético e o ácido propiônico, bem como a concentração total de os ácidos graxos voláteis.

Não foi detectada diferença pelo teste $\mathrm{F}$ ao nível de $5 \%$ de probabilidade para a concentração individual dos ácidos graxos voláteis, em razão da variável tratamento e para interação entre tratamento e tempo. Com base no exposto, é possível afirmar que as concentrações médias dos ácidos graxos voláteis analisados em função do tempo, podem representar a média dos tratamentos ao longo do período experimental, conforme apresentados na Tabela 8. O teste $\mathrm{F}$ acusou diferença da variável tempo para as concentrações dos ácidos butírico $(\mathrm{P}<0,01)$, isobutírico $(\mathrm{P}<0,05)$ valérico $(\mathrm{P}<0,01)$ e isovalérico $(\mathrm{P}<0,01)$. Assim, pode-se concluir que houve alteração da concentração destes ácidos, ao longo dos dias de coleta, enquanto esta variável não foi relevante para a concentração dos ácidos acético $(\mathrm{P}=0,57)$ e apresentou tendência para alterações na concentração molar de ácido propiônico $(\mathrm{P}=0,06)$.

Não foi detectada diferença pelo teste $\mathrm{F}$ ao nível de $5 \%$ de significância para a relação entre os ácidos acético e propiônico em razão da variável tratamento $(\mathrm{P}=0,72)$, tempo $(\mathrm{P}=0,16)$ e para interação entre tratamento e tempo $(\mathrm{P}=0,73)$. Portanto, pode-se afirmar que a proporção destes em função do tempo não se alterou ao longo dos dias de coleta. Os valores dessa relação sumarizados na Tabela 8 podem representar a média de todos os tratamentos ao longo do período experimental.

Não foi detectada diferença significativa pelo teste $F$ ao nível de $5 \%$ de significância para a concentração média dos ácidos graxos voláteis totais no fluido ruminal em razão da variável tratamento $(\mathrm{P}=0,96)$, tempo $(\mathrm{P}=0,28)$ e para interação entre tratamento e tempo $(\mathrm{P}=0,46)$ conforme apresentado nas Tabelas 8 e 9.

No que se refere ao padrão de fermentação ruminal da dieta, pode-se observar nas Tabelas 8 e 9, que a proporção entre os ácidos acético (C2), propiônico (C3) e butírico. 
(C4) em relação ao somatório total de ácidos, sugerem uma relação de 70:20:10 que, acompanhada, de seus respectivos valores de $\mathrm{pH}$, refletem um padrão de fermentação ruminal típico de animais alimentados exclusivamente com volumosos. Desta forma, pode-se inferir que não foram observadas mudanças específicas na população de microrganismos fibrolíticos, mantendo elevada a digestibilidade da fibra. A dose de concentrado utilizado na dieta possivelmente ajudou a manter a biodiversidade de microrganismos ruminais. $\mathrm{O}$ uso de inoculante bacteriano-enzimático aliado a diferentes níveis de matéria seca, não causou impacto sobre o padrão de fermentação ruminal.

A produção de ácidos é resultante das características do alimento e do produto final de fermentação da matéria orgânica, no rúmen, ou consumido na silagem (Allen, 1997). A via de fermentação é determinada pela composição da população microbiana e, grandes mudanças são determinadas pela dieta basal, particularmente pelo tipo de carboidrato desta dieta. A forma física, o nível de consumo, a freqüência de alimentação e o uso de aditivos químicos, também podem interferir no padrão de fermentação (France \& Siddons, 1993).

Ensilar forragens com alta umidade, possibilita a ocorrência de grandes perdas pelo processo fermentativo, o aumento da intensidade de fermentação resulta em aumento da produção dos ácidos acético e butírico. A acidificação na ensilagem do meio, pode contribuir para reduzir perdas, mas, também poderá reduzir o consumo voluntário pelos animais (Erdman, 1993).

Variação no pH ruminal não altera a taxa de absorção de ácido acético, 0,31 hora $^{-1}$, mas há aumento na taxa de absorção do ácido propiônico de 0,35 para 0,68 hora $^{-1} \mathrm{e}$ do ácido butírico de 0,28 para 0,85 hora $^{-1}$ com o decréscimo no valor de $\mathrm{pH}$ de 7,2 para 4,5. A diferença da taxa média de absorção de AGV ocorre quando houver um gradiente entre o rúmen e a circulação, para o ácido butírico, e em algumas vezes para o propiônico, dependendo da extensão do metabolismo epitelial, do rúmen. Embora a maior absorção de $\mathrm{AGV}$ resulte em incremento na taxa de dissociação de ácidos, os efeitos desta causam alterações no $\mathrm{pH}$ ruminal, devido às diferenças na taxa de absorção. $\mathrm{O}$ ácido acético causa maior impacto na redução do $\mathrm{pH}$ ruminal que o ácido propiônico que por sua vez, é mais importante que o butirato. Aumentos da taxa de absorção de 
AGV, no epitélio ruminal e, consequentemente, elevação da taxa de absorção de AGV caracterizam maior concentração molar total de ácidos, no rúmen (Allen, 1997).

A silagem emurchecida de azevém perene resultou na diminuição na concentração de amônia na silagem e promoveu aumento da concentração molar ruminal de acetato e da relação acetato:propionato. Nesta adição de inoculante bacteriano ou o emurchecimento alteram o $\mathrm{pH}$, a concentração molar de propionato, butirato, valérico, e não glicogênicos e a proporção (acetato+butirato)/propionato, no rúmen. (Keady \& Mayne, 2001). Segundo estes mesmos autores, o tempo de coleta das amostras alterou o pH $(\mathrm{P}<0,01)$, a concentração de amônia $(\mathrm{P}<0,01)$, AGVs totais $(\mathrm{P}<0,01)$, acetato $(\mathrm{P}<0,01)$, butirato $(\mathrm{P}<0,01)$, valérico $(\mathrm{P}<0,01)$, bem como a relação acetato:propionato $(\mathrm{P}<0,01)$, não havendo diferença $(\mathrm{P}>0,05)$ para a concentração molar de propionato, de ácidos graxos voláteis não glicogênicos e da relação (acetato+butirato)/propionato. A fonte de energia e o tipo de silagem não apresentaram interação $(\mathrm{P}>0,05)$ com o tempo de amostragem, para os parâmetros de fermentação mensurados.

O fluxo de absorção de $\mathrm{AGV}$, pelo rúmen, também pode ser relacionado positivamente com a superfície específica de absorção das papilas ruminais; a medida que a taxa de absorção diminui, o volume de líquidos aumenta de 10 para 30 litros. $\mathrm{O}$ teor de FDN da forragem estimula a motilidade ruminal, resultando em uma intensa mistura da ingesta, no rúmen. Esta ação eleva a concentração de AGVs no epitélio, que pode resultar em um aumento da absorção de ácidos, oriundos da fermentação e renovação, no rúmen, como resultado do gradiente (Allen, 1997).

\subsubsection{Evolução temporal da concentração de ácidos graxos voláteis}

A concentração de ácidos graxos voláteis no fluido ruminal, apresentada nas Figuras 7 a 14, revelou picos mais acentuados nas primeiras horas após a alimentação, para os tratamentos recebendo silagens com uma concentração de matéria seca mais elevada. A provável explicação para o ocorrido pode ser baseada na suposta diluição tanto dos componentes que serviram de substrato para ação dos microrganismos 
ruminais, como para os produtos originados da fermentação em dietas contendo silagens com menor teor de matéria seca.

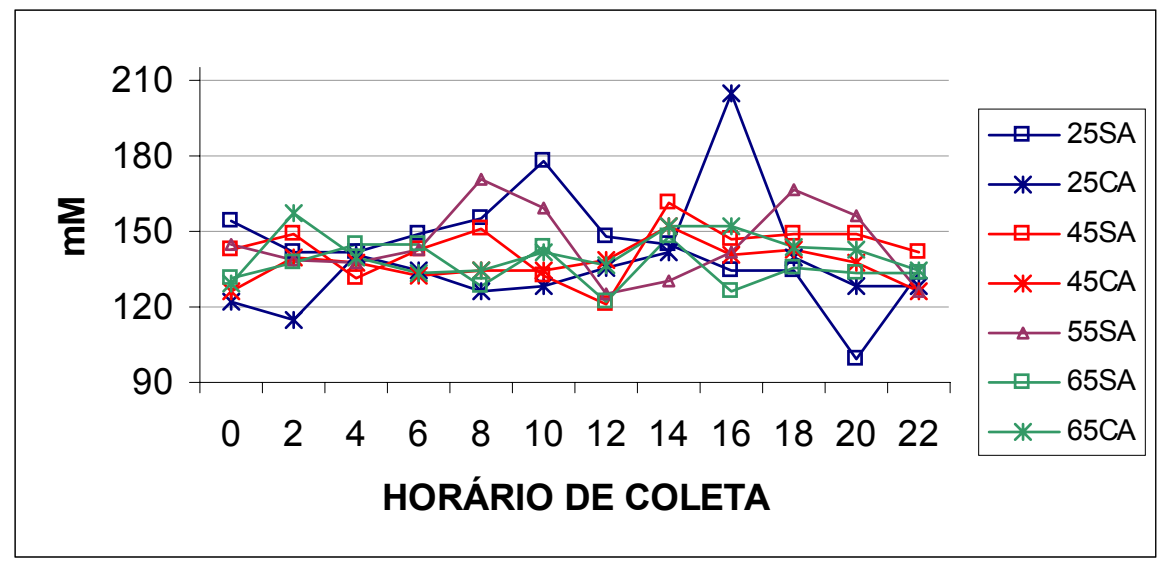

Figura 7 - Efeito das dietas experimentais sobre a evolução diária da concentração molar de ácidos graxos voláteis totais, no fluido ruminal.

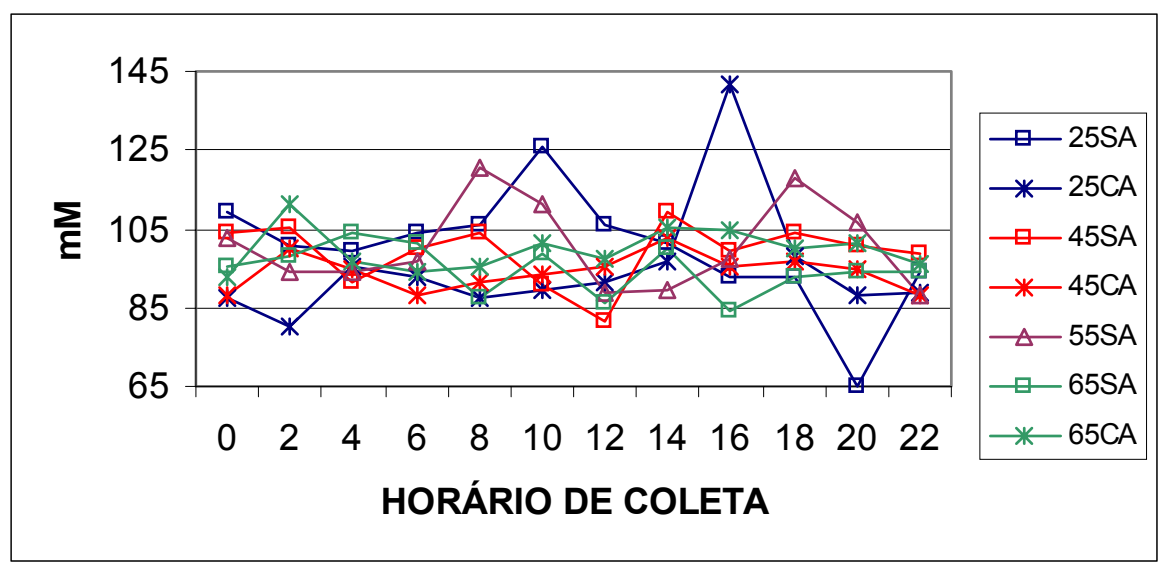

Figura 8 - Efeito das dietas experimentais sobre a evolução diária da concentração molar de ácido acético, no fluido ruminal. 


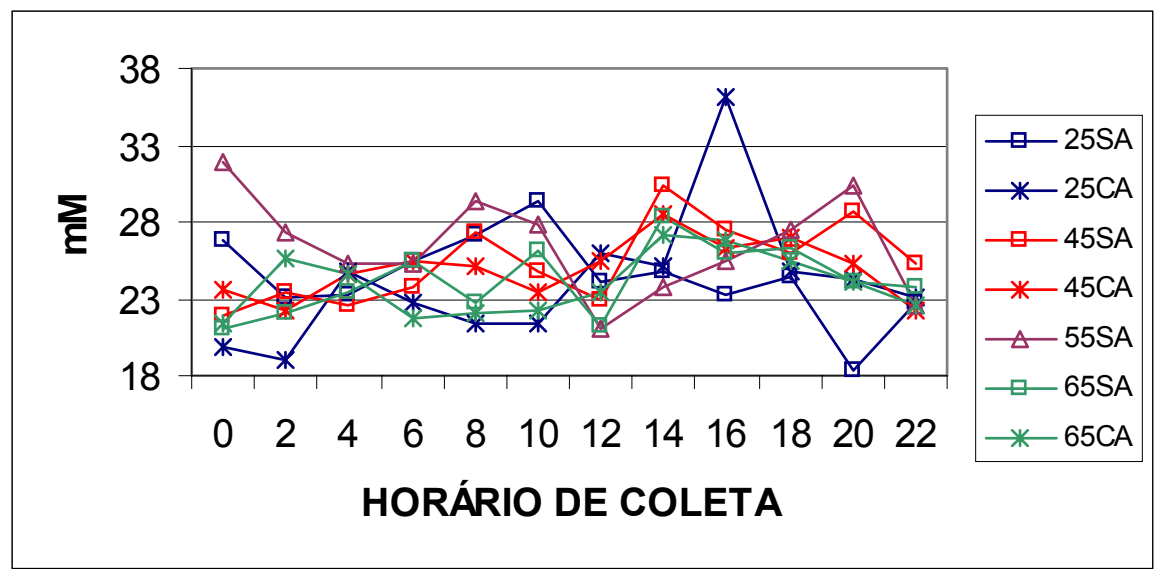

Figura 9 - Efeito das dietas experimentais sobre a evolução diária da concentração molar de ácido propiônico, no fluido ruminal.

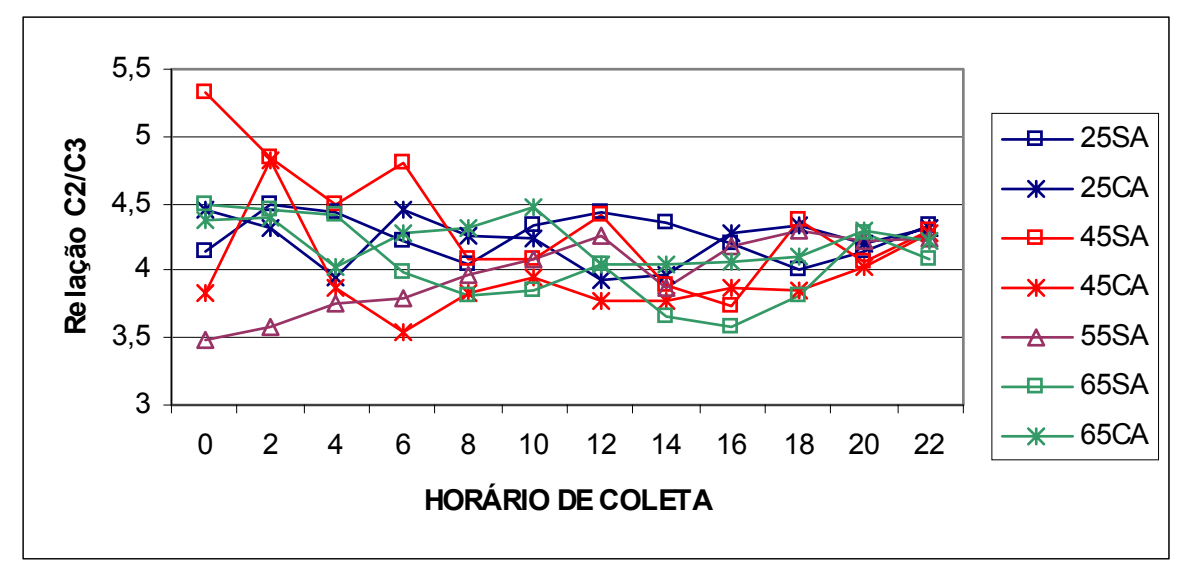

Figura 10 - Efeito das dietas experimentais sobre a evolução diária da concentração molar da relação ácido acético:propiônico, no fluido ruminal.

Os valores da relação acetato:propionato, encontrados na Figura 10, praticamente não sofreram alterações durante os horários de coleta, provavelmente devido ao fato de que tendências observadas para ácido acético e propiônico apresentarem padrões 
semelhantes de elevação ao longo do dia, com aumentos a partir de duas horas após a alimentação, atingindo picos de baixa ao redor dos horários de alimentação.

A evolução temporal das concentrações de butirato, isobutirato, valérico e isovalérico no fluido ruminal estão apresentadas nas Figuras 11 a 14, onde pode-se observar que os aumentos na concentração dos mesmos ocorreram com a elevação do consumo de matéria seca, após as alimentações diárias.

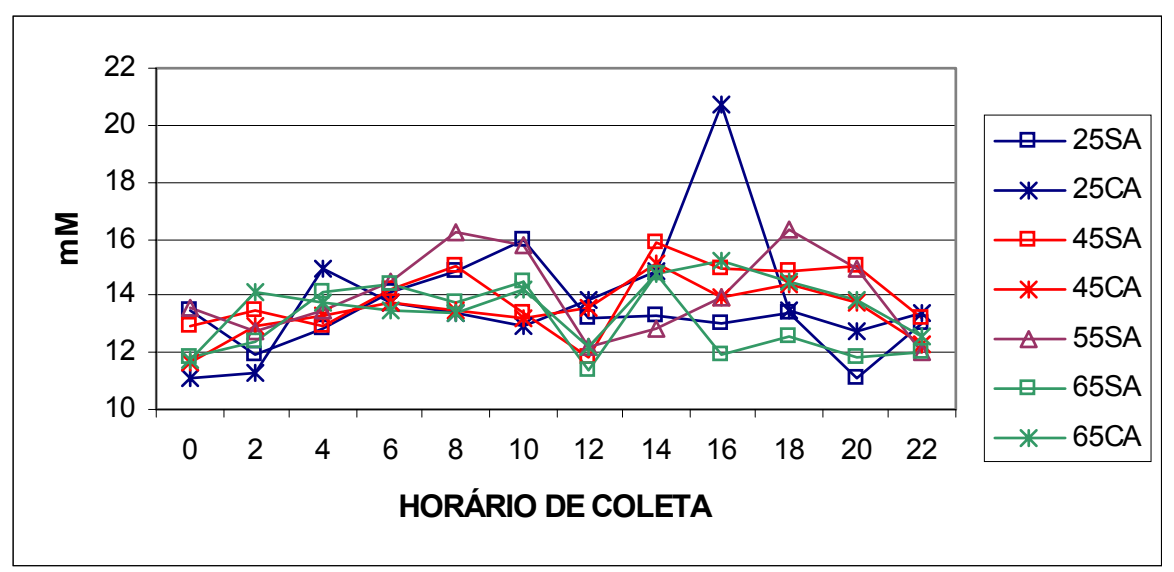

Figura 11 - Efeito das dietas experimentais sobre a evolução diária da concentração molar de ácido butírico, no fluido ruminal.

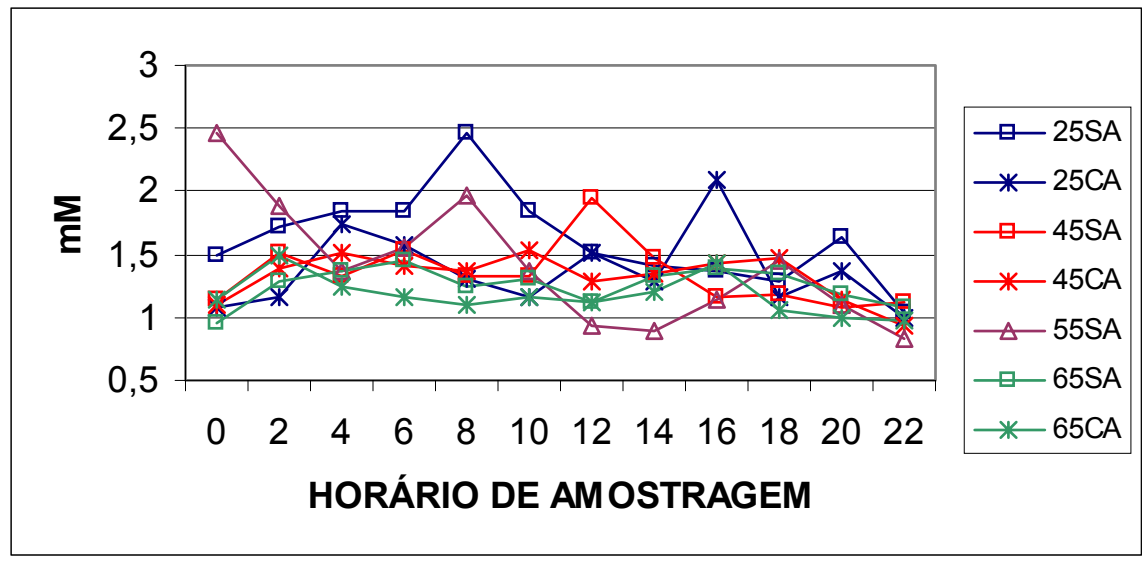

Figura 12 - Efeito das dietas experimentais sobre a evolução diária da concentração molar de ácido isobutírico, no fluido ruminal. 


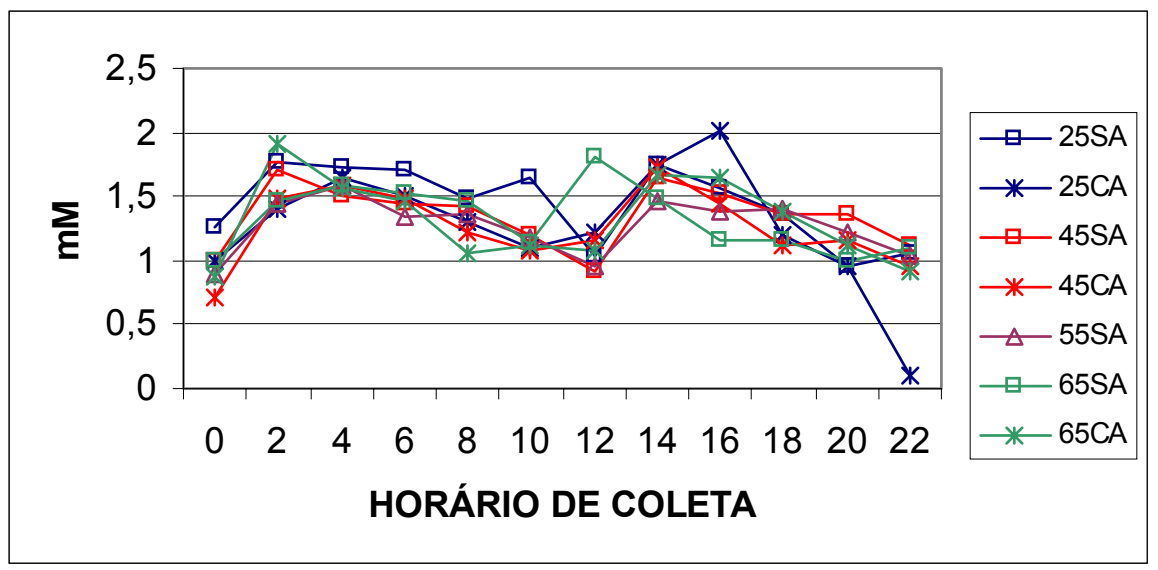

Figura 13 - Efeito das dietas experimentais sobre a evolução diária da concentração molar de ácido valérico, no fluido ruminal.

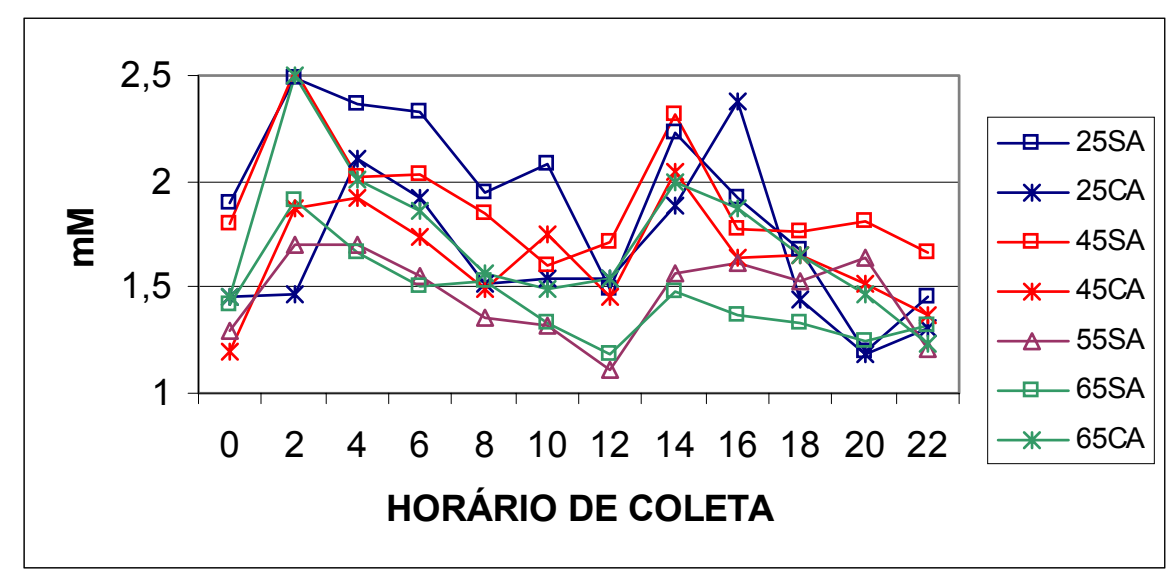

Figura 14 - Efeito das dietas experimentais sobre a evolução diária da concentração molar de ácido isovalérico, no fluido ruminal.

\subsubsection{Nitrogênio amoniacal}

Não foi detectada diferença pelo teste $\mathrm{F}$ ao nível de $5 \%$ de probabilidade para a concentração de amônia ruminal em razão da variável tratamento $(\mathrm{P}=0,75)$ e para a interação entre tratamento e tempo $(\mathrm{P}=0,64)$. Portanto, pode-se inferir que os valores médios da concentração de amônia em função do tempo, sumarizados na Tabela 9 , 
representam a média dos tratamentos ao longo do período experimental. O teste $\mathrm{F}$ acusou diferença para a variável tempo $(\mathrm{P}<0,01)$, sugerindo que houve alteração do valor de $\mathrm{N}$-amoniacal ruminal ao longo dos horários de coleta.

O uso de inoculante bacteriano-enzimático não promoveu alteração sobre o perfil de $\mathrm{N}$-amoniacal, no rúmen, dos animais recebendo silagem emurchecida Tifton 85 . A verificação de seu comportamento, ao longo do dia, sugere que os valores $\mathrm{N}$-amoniacal atingiram seus picos duas horas após a alimentação, pois nestes horários a fermentação ruminal se apresentou intensa, decorrente da maior disponibilidade dos nutrientes das dietas.

Segundo Van Soest (1994) um nível adequado de N-amoniacal no rúmen, para garantir suficiência aos processos de fermentação e síntese de proteína microbiana, seria

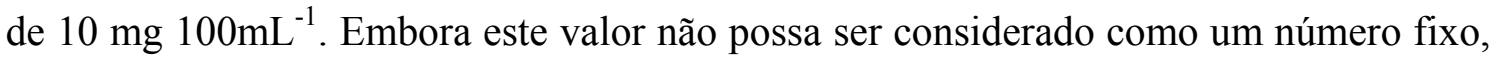
pois a capacidade bacteriana de síntese de proteínas requer aumento da concentração de amônia. No presente experimento, a média geral entre tratamentos revelou $6,31 \mathrm{mg} \mathrm{dL}^{-1}$ conforme Tabela 8 , havendo amplitude de 3,68 a 10,83 $\mathrm{mg} \mathrm{dL}^{-1}$ entre os horários de coleta de fluido ruminal, como apresentados na Tabela 9.

A fonte preferencial de nitrogênio para os microrganismos do rúmen, é a amônia e parece que sua utilização, pelas bactérias, não ocorre por simples difusão passiva, mas sim por um mecanismo específico de transporte. Existem ao menos dois possíveis mecanismos de transporte: utilizando a glutamina sintetase (que exige ATP) e outro usando glutamato desidrogenase. Para existir uma população típica de microrganismos celulolíticos, alguns fatores propiciados pelo proventrículo têm importância, isto é, a amônia auxilia a manutenção de um $\mathrm{pH}$ mais elevado, principalmente, quando sua presença no líquido ruminal for expressiva (Lucci, 1997).

Pode-se concluir, através da análise conjunta de todos os parâmetros ruminais e pela baixa proporção de concentrado nas dietas, que as silagens emurchecidas de Tifton 85 apresentaram excesso de nitrogênio solúvel. Possivelmente, houve falta de sincronia no rúmen, entre energia e os compostos nitrogenados, principalmente para os tratamentos contendo menor teor de matéria seca, pois a produção de AGVs totais se 
manteve dentro de um patamar constante, seguido de um ligeiro declínio, após os picos de amônia.

Keady \& Mayne (2001), encontraram efeito significativo para o tempo de amostragem, durante 24 horas de observação da concentração de N-amoniacal, a partir do oferecimento diário de alimentos às 6:00 horas, com tipo de processamento na silagem. Às 11:00 horas a concentração de amônia foi significativamente mais elevada para a silagem emurchecida por 24 horas e inoculada, comparada com uma silagem convencional. Enquanto que, às 12:00, 14:00 e 18:00 horas a concentração de amônia foi significativamente maior para a silagem emurchecida por 24 horas e inoculada quando comparada a silagem úmida, inoculada exclusivamente.

Valores similares foram observados por Ribeiro et al. (2001a) que não encontraram efeito da maturidade da planta sobre as concentrações de $\mathrm{N}-\mathrm{NH}_{3}$, em rações contendo feno de Tifton 85 verificando que as concentrações de $\mathrm{N}$-amoniacal não foram elevadas, o que pode ser atribuído a um bom sincronismo na digestão de carboidratos e proteínas, resultando em máxima concentração de $\mathrm{N}$-amoniacal em torno de 9,7 $\mathrm{mg}$ $100 \mathrm{~mL}^{-1}$, tendo ocorrido às 1,4 horas após a alimentação dos animais.

\subsubsection{Evolução temporal sobre a concentração de nitrogênio amoniacal}

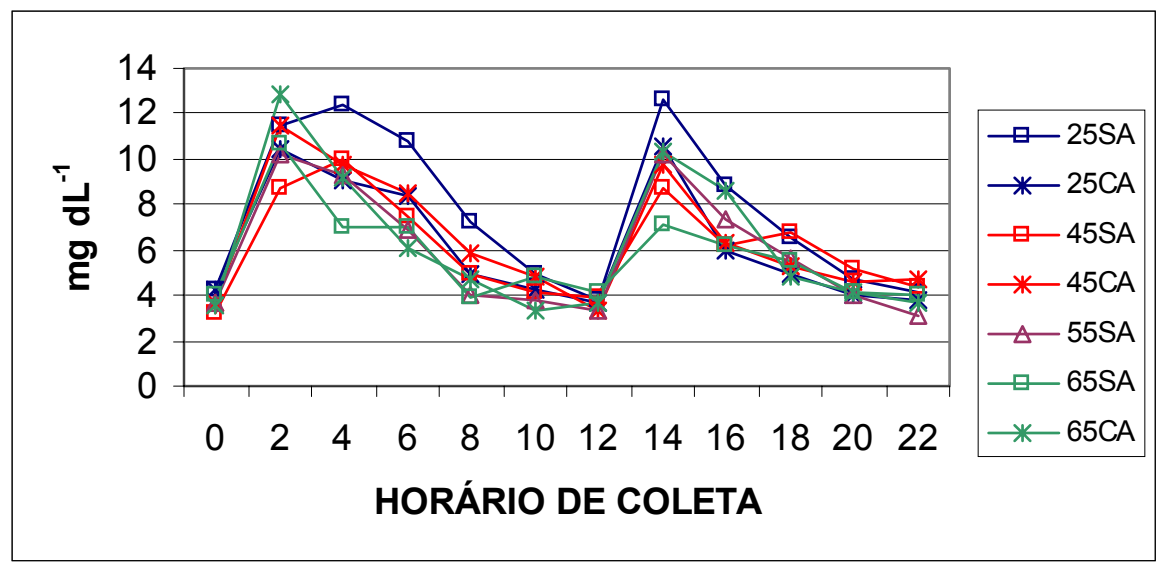

Figura 15 - Efeito das dietas experimentais sobre a evolução diária da concentração de nitrogênio amoniacal, no fluido ruminal. 
$\mathrm{Na}$ Figura 15, além da tendência geral de mostrar que os picos de $\mathrm{N}$-amoniacal ocorreram duas a quatro horas após a alimentação, nos tratamentos contendo silagem mais úmida como o 25SA, os picos mais intensos e a extensão da concentração de Namoniacal permanecem mais elevada por maior tempo. Este fato possivelmente reflete a maior proteólise ocorrida em silagens mais úmidas de Tifton 85, conforme descrito anteriormente por Castro (2002).

\subsection{Digestibilidade aparente no trato digestivo}

A análise da digestibilidade aparente no trato digestivo total, não acusou diferença significativa entre os tratamentos pelo teste $\mathrm{F}$, para os parâmetros, matéria orgânica digestível $(\mathrm{P}=0,07)$, proteína bruta digestível $(\mathrm{P}=0,22)$, FDA digestível $(\mathrm{P}=0,20)$ e hemicelulose digestível $(\mathrm{P}=0,14)$. Assim, pode-se considerar que as médias dos tratamentos encontrada na Tabela 10 representam as variáveis descritas acima. Porém, diferença significativa se fez para as variáveis matéria seca digestível $(\mathrm{P}=0,04)$ e FDN digestível $(\mathrm{P}=0,02)$, que foram maximizadas em silagens com $45 \%$ de concentração de MS.

Andrade et al. (1997) verificaram valores similares para o coeficiente de digestibilidade da matéria seca $(65,3 \%)$, matéria orgânica $(71,3 \%)$ e FDN $(65,1 \%)$ para silagem emurchecida do capim Coastcross $n^{\circ}$, porém o valor estimado para NDT $(76 \%)$ foi superior. Yan et al. (1997) encontraram valores mais elevados para o coeficiente de digestibilidade da matéria orgânica(76 vs. 78\%), da energia bruta (72 vs. $73 \%$ ) e do nitrogênio (67 vs. 69\%), para silagens emurchecidas de azevém perene e inoculada contra àquelas exclusivamente emurchecidas.

Observações referentes à variável matéria seca digestível, propõem comportamento quadrático, devido ao aumento da concentração de matéria seca $(\mathrm{P}=0,05)$, com pico para concentração de matéria seca próximo a $45 \%$. A presença do inoculante bacteriano-enzimático causou efeito negativo sobre o coeficiente de digestibilidade das silagens $(\mathrm{P}=0,06)$. 
Tabela 10. Médias dos quadrados mínimos para os coeficientes de digestibilidade, NDT estimado e ingestão de nutrientes digestíveis para matéria seca, matéria orgânica, proteína bruta, FDN, FDA e hemicelulose em rações contendo silagens de capim Tifton 85 .

\begin{tabular}{|c|c|c|c|c|c|c|c|c|c|c|c|c|c|}
\hline \multirow[t]{2}{*}{ Variável } & \multicolumn{3}{|c|}{ Com aditivo } & \multicolumn{4}{|c|}{ Sem aditivo } & \multirow[t]{2}{*}{$\mathrm{CV}$} & \multicolumn{5}{|c|}{ Contrastes $^{1}(\mathrm{P}<)$} \\
\hline & 25 & 45 & 65 & 25 & 45 & 55 & 65 & & $\mathbf{L}$ & $\mathbf{Q}$ & AD & $\mathbf{L} * \mathbf{A D}$ & $\mathbf{Q}^{*} \mathbf{A D}$ \\
\hline \multicolumn{14}{|l|}{ Matéria seca } \\
\hline$\%$ & $67,8^{\mathrm{bc}}$ & $71,8^{\mathrm{ab}}$ & $71,7^{\mathrm{ab}}$ & $71,4^{\mathrm{ab}}$ & $73,3^{\mathrm{a}}$ & $71,2^{\mathrm{ab}}$ & $69,6^{\mathrm{bc}}$ & 4,2 & 0,11 & 0,05 & 0,06 & 0,19 & 0,78 \\
\hline $\mathrm{kg} \operatorname{dia}^{-1}$ & 4,61 & 5,09 & 5,13 & 4,98 & 5,13 & 4,85 & 4,75 & & & & & & \\
\hline \multicolumn{14}{|l|}{ Matéria orgânica } \\
\hline$\%$ & $68,2^{\mathrm{a}}$ & $72,3^{\mathrm{a}}$ & $72,2^{\mathrm{a}}$ & $71,8^{\mathrm{a}}$ & $73,6^{\mathrm{a}}$ & $72,3^{\mathrm{a}}$ & $69,9^{\mathrm{a}}$ & 4,4 & 0,09 & 0,13 & 0,15 & 0,16 & 0,85 \\
\hline $\mathrm{kg} \operatorname{dia}^{-1}$ & 4,27 & 4,74 & 4,79 & 4,60 & 4,76 & 4,53 & 4,42 & & & & & & \\
\hline \multicolumn{14}{|l|}{ Proteína bruta } \\
\hline$\%$ & $68,0^{\mathrm{a}}$ & $71,8^{\mathrm{a}}$ & $69,0^{\mathrm{a}}$ & $70,4^{\mathrm{a}}$ & $69,7^{\mathrm{a}}$ & $68,7^{\mathrm{a}}$ & $66,2^{\mathrm{a}}$ & 5,9 & 0,83 & 0,21 & 0,84 & 0,50 & 0,22 \\
\hline $\mathrm{kg} \operatorname{dia}^{-1}$ & 0,49 & 0,60 & 0,52 & 0,58 & 0,55 & 0,46 & 0,43 & & & & & & \\
\hline \multicolumn{14}{|l|}{ FDN } \\
\hline$\%$ & $67,0^{\mathrm{b}}$ & $73,4^{\mathrm{a}}$ & $71,1^{\mathrm{a}}$ & $70,6^{\mathrm{a}}$ & $73,7^{\mathrm{a}}$ & $72,6^{\mathrm{a}}$ & $70,8^{\mathrm{a}}$ & 4,6 & 0,02 & 0,01 & 0,44 & 0,05 & 0,71 \\
\hline $\mathrm{kg} \operatorname{dia}^{-1}$ & 2,74 & 3,04 & 2,95 & 2,83 & 3,09 & 2,95 & 2,97 & & & & & & \\
\hline \multicolumn{14}{|l|}{ FDA } \\
\hline$\%$ & $60,4^{\mathrm{a}}$ & $66,2^{\mathrm{a}}$ & $68,0^{\mathrm{a}}$ & $64,2^{\mathrm{a}}$ & $66,2^{\mathrm{a}}$ & $65,0^{\mathrm{a}}$ & $64,4^{\mathrm{a}}$ & 7,7 & 0,04 & 0,29 & 0,17 & 0,81 & 0,34 \\
\hline $\mathrm{kg} \operatorname{dia}^{-1}$ & 1,64 & 2,15 & 2,07 & 1,82 & 1,80 & 1,87 & 1,86 & & & & & & \\
\hline \multicolumn{14}{|l|}{ Hemicelulose } \\
\hline$\%$ & $80,7^{\mathrm{a}}$ & $83,0^{\mathrm{a}}$ & $78,1^{\mathrm{a}}$ & $86,0^{\mathrm{a}}$ & $86,8^{\mathrm{a}}$ & $86,0^{\mathrm{a}}$ & $82,5^{\mathrm{a}}$ & 7,4 & 0,60 & 0,30 & 0,85 & 0,01 & 0,26 \\
\hline $\mathrm{kg} \operatorname{dia}^{-1}$ & 1,02 & 1,14 & 0,95 & 0,96 & 1,02 & 0,87 & 0,99 & & & & & & \\
\hline NDT $^{2}$ Forragem & $49,5^{\mathrm{b}}$ & $50,0^{\mathrm{b}}$ & $50,1^{\mathrm{b}}$ & $52,0^{\mathrm{a}}$ & $52,1^{\mathrm{a}}$ & $50,1^{\mathrm{b}}$ & $49,1^{\mathrm{b}}$ & 2,6 & 0,22 & 0,16 & 0,01 & 0,02 & 0,28 \\
\hline NDT $^{2}$ Ração & $55,7^{\mathrm{b}}$ & $56,0^{\mathrm{b}}$ & $56,1^{\mathrm{b}}$ & $57,6^{\mathrm{a}}$ & $57,8^{\mathrm{a}}$ & $56,2^{\mathrm{b}}$ & $55,4^{\mathrm{b}}$ & 1,8 & 0,22 & 0,16 & 0,01 & 0,02 & 0,28 \\
\hline
\end{tabular}

Contrastes = L: matéria seca efeito linear; Q: matéria seca efeito quadrática; AD: aditivo; L*AD: interação matéria seca linear e aditivo; Q*AD: interação matéria seca quadrática e aditivo.

${ }^{2}$ NDT estimado de acordo com o NRC- gado de leite 2001- Equação de Weiss modificada. 
Para os constituintes da fibra, a variável FDA digestível, apresentou efeito linear positivo $(\mathrm{P}=0,04)$ com o aumento da concentração de matéria seca, enquanto para a variável FDN digestível pôde-se verificar efeito linear positivo $(\mathrm{P}<0,05)$ e quadrático $(\mathrm{P}<0,05)$ com pico para concentração de matéria seca próxima a 45\%. Da mesma forma, o aumento da concentração de matéria seca, estabeleceu efeito linear positivo $(\mathrm{P}<0,05)$ para silagem inoculada, contudo seus coeficientes de digestibilidade se mostraram inferiores. A variável hemicelulose digestível apresentou efeito linear negativo $(\mathrm{P}<0,05)$ para a interação entre a concentração de matéria seca e aditivo. Assim, as silagens inoculadas apresentaram sempre menor coeficiente de digestibilidade para este parâmetro. Nenhum registro de interação significativa foi detectado para as variáveis matéria orgânica digestível e proteína bruta digestível.

Charmley \& Thomas (1987) observaram que a técnica do emurchecimento reduziu a digestibilidade da matéria seca. Contudo, efeito similar pôde ser observado na matéria orgânica, do nitrogênio e da energia bruta, $(\mathrm{P}<0,01)$. Apesar disto, o emurchecimento não influenciou o consumo de matéria seca, nem o consumo de energia digestível, porém melhorou o consumo de nitrogênio para novilhos recebendo silagem de azevém perene ad libitum.

A provável explicação para a diferença significativa $(\mathrm{P}<0,05)$ encontrada para as digestibilidades da matéria seca e do FDN, não verificada para matéria orgânica $(\mathrm{P}>0,05)$, independente da concentração de matéria seca, esteja na alteração da solubilidade da fração de minerais da planta, decorrente do processo de desidratação da forragem ao campo. A lise de células ocorrida com o emurchecimento da forragem poderia ao menos, parcialmente, explicar as variações de solubilidade dos minerais presentes na forragem fresca. Além disto, apesar de não ter havido efeito significativo $(\mathrm{P}>0,05)$ para a digestibilidade de matéria orgânica, houve tendência para significância $(\mathrm{P}=0,07)$ que em ensaios metabólicos pode ser considerada para comparação de tratamentos.

Foram observados efeitos significativos do período experimental sobre as variáveis matéria seca digestível $(\mathrm{P}<0,05)$, hemicelulose digestível $(\mathrm{P}<0,01)$ e FDN 
digestível $(\mathrm{P}<0,05)$. Estas diferenças, possivelmente, causaram impacto sobre $\mathrm{o}$ coeficiente de variação, uma vez que as observações descritas no item composição bromatológica (Tabela 3), trazem indícios de que ocorreram variações da concentração de matéria seca e da fração FDN, entre fardos correspondentes ao mesmo tratamento. Além disto, houve alteração da quantidade e qualidade das sobras das dietas, observadas, para um mesmo tratamento e em diferentes períodos, o que sugere seletividade da ingestão de alimentos. Este fato é considerado relevante, e pode ser caracterizado na Tabela 5 pelos coeficientes de variação relativos às proporções de sobras recusadas.

von Keyserlingk et al. (1996) avaliando as características de degradabilidade da matéria seca e da proteína bruta nas silagens de milho, de gramínea e em fenos de gramínea e alfafa, observaram que os coeficientes de correlação com a composição inicial de nutrientes nas forragens (MS, NIDA, FDN, FDA, PB e suas frações A e B), não foram significativos $(\mathrm{P}>0,05)$. Não obstante, especificamente em silagens de gramíneas foram observadas diferenças significativas $(\mathrm{P}<0,05)$ correlacionadas com $\mathrm{O}$ FDN inicial da forragem e a degradabilidade da fração B e da PB. Embora a degradabilidade efetiva da proteína bruta em feno de gramíneas apresente íntima relação $(\mathrm{P}<0,01)$ com o FDN inicial do alimento $(\mathrm{r}=-0,91)$, não resultou $(\mathrm{P}>0,05)$ em correlação com o conteúdo de FDN inicial para os fenos de alfafa. Em outra avaliação, a degradabilidade da proteína bruta da alfafa exibiu diferença significativa $(\mathrm{P}<0,05)$ relacionada com o conteúdo inicial de matéria seca $(\mathrm{r}=0,52)$.

O desaparecimento de proteína no trato digestivo total, para ambos os tipos de silagens testadas, variou de 77,6 a 90,0\%, para a silagem de milho, e de 64,5 para 93,0\% para silagens de gramíneas. Nos fenos de alfafa e de gramínea a média de desaparecimento em 12 horas foi 65,37 e 54,85\%, respectivamente. Em ambos tipos de feno estudados, uma porcentagem mínima de matéria seca desapareceu, no intestino, e as observações ocorridas exclusivamente do intestino tenderam a zero, considerando um valor máximo de $23,5 \%$ e $18,4 \%$ para os fenos de gramínea e alfafa, respectivamente. $\mathrm{O}$ desaparecimento médio da proteína bruta no intestino foi de 18,07 e 22,03\%, para fenos de alfafa e gramínea, respectivamente. Já para o trato digestivo total o desaparecimento 
de proteína bruta variou entre 81,2 a 93,8\%, para o feno de alfafa, e de 71,7 para 93,4\%, para o feno de gramínea (von Keyserlingk et al., 1996).

As observações mencionadas acima, confirmam que a degradabilidade ruminal de carboidratos estruturais é correlacionada com o teor de FDN inicial da forragem e suas respectivas frações nitrogenadas N-FDN, N-FDA e $B_{3}$. Portanto, uma explicação possível para o menor coeficiente de digestibilidade do FDN verificado para o tratamento 25SA (Tabela 10) pode ser confirmado pela análise bromatológica desta forragem apresentada na Tabela 3, revelando o maior teor de FDN associado a menor proporção de N-FDN. Outra confirmação pode ser baseada pelo coeficiente de digestibilidade da matéria orgânica $(\mathrm{P}=0,07)$, que confirma a similaridade deste tratamento como o tratamento 25CA. Como esta semelhança também é admitida para o tratamento 65SA, possivelmente para o capim Tifton 85 as características observadas para concentração de matéria seca talvez tenham correlação.

Guimarães et al. (2001), utilizando quatro novilhos da raça holandesa, com peso médio de $340 \mathrm{~kg}$ e recebendo dois níveis de volumosos (30 e 70\%), notaram efeito significativo do nível de volumoso sobre a digestibilidade ruminal de FDA e FDN, digestibilidade intestinal e total da MS, MO, PB, amido e digestibilidade total da energia bruta. A explicação, contraria aos resultados, do presente experimento, foi fundamentada por mudanças provocadas no ambiente ruminal, em função da proporção de concentrado.

De acordo com os relatos de Wright et al. (2000) sobre o efeito do aumento da proporção de concentrado em rações baseadas em silagens emurchecidas e silagens convencionais, houve decréscimo de resposta sobre a taxa de ganho de peso diário para silagens emurchecidas em função do tempo de desidratação. Assim, pode-se concluir que com a elevação da concentração de matéria seca pelo emurchecimento da planta a campo, possivelmente, a digestibilidade da matéria seca tenha diminuído Contudo, devido a proposta inicial do presente trabalho em se fixar a quantidade de concentrado na composição da ração, a interação entre emurchecimento e nível de concentrado não pôde ser avaliada. 
De acordo com os resultados obtidos na Tabela 10, o efeito do aditivo bacterianoenzimático não pôde ser correlacionado com nenhum beneficio para os coeficientes de digestibilidade analisados, corroborando assim, com as observações obtidas por Rodrigues et al. (2001a,b,c,d,e), realizadas com diferentes aditivos microbianos associados a diversas fontes de forragem. Excepcionalmente, para a silagem de alfafa, o inoculante Silobac aumentou as digestibilidades aparentes de matéria seca, do extrato não nitrogenado, do FDN, do FDA e do amido o que resultou em aumento do NDT em 4,9\% (Rodrigues et al., 2001a). 


\section{CONCLUSÕES}

Pode se constatar que, após a abertura dos silos, silagens mais úmidas apresentaram proporção de perdas inferiores às silagens com uma concentração de matéria seca mais elevada, possivelmente, pela alteração no padrão de fermentação das silagens que, provavelmente, não decorreu do uso do inoculante bacteriano-enzimático. O comportamento das silagens após a abertura poderá ser amplamente alterado mediante a adoção de maiores taxas diárias de retirada de silagens.

A magnitude de variação observada nos parâmetros físico-químicos das silagens avaliadas, decorrentes das práticas de emurchecimento e/ou inoculante bacterianoenzimático, não causam efeito consistente nas variáveis de cinética ruminal, digestibilidade de nutrientes, comportamento ingestivo e consumo voluntário em bovinos.

A prática do emurchecimento se caracteriza por relatos conflitantes na literatura, cuja inconsistência de resultados aponta para a importância das condições vigentes durante o processo de desidratação da forragem a campo. A antítese desses resultados se estende aos parâmetros de metabolismo e desempenho de animais.

Analogamente, os resultados com inoculantes bacterianos-enzimáticos são contraditórios, onde a menor eficiência do aditivo testado na silagem de capim Tifton 85 poderia ser atribuída a supostas causas como condições ecológicas inadequadas aos microrganismos inoculados e falta de especificidade do complexo bacteriano-enzimático a esta forragem, fato que inclusive sugere a continuidade destes estudos apoiado por avaliação microbiológica da forragem, antes da ensilagem. 
As silagens testadas, independente do tratamento, foram caracterizadas como volumosos de bom valor nutritivo, traduzido pelos elevados valores de digestibilidade. Este fato, indica o potencial dessa forma de conservação e estimula a caracterização desses efeitos em ensaios voltados à avaliação do desempenho de animais. 


\section{REFERÊNCIAS BIBLIOGRÁFICAS}

AGNEW, R.E.; CARSON, M.T. The effect of a silage additive and level of concentrate supplementation on silage intake, animal performance and carcass characteristics of finishing beef cattle. Grass and Forage Science, v.55, p.114-124, 2000.

AGUIAR, R.N.S.; CRESTANA, R.F.; BALSALOBRE, M.A.A.; NUSSIO, L.G.; SANTOS, P.M.S.; CORSI, M. Efeito do tamanho de partículas na composição da fração nitrogenada de silagem de capim tanzânia. In: ANAIS DA REUNIÃO ANUAL DA SOCIEDADE BRASILEIRA DE ZOOTECNIA, 38., Piracicaba, 2001. Anais Piracicaba: FEALQ, 2001. p.314-316.

ALBRIGHT, J.H.; ARAVE, C.W. The behaviour of cattle. New York: Cab international, 1997. cap.5, p.100-126: Feeding behaviour.

ALLEN, M.S. Relationship between fermentation acid production in the rumen and the requirement for physically effective fiber. Journal of Dairy Science, v.80, p.1447$1462,1997$.

ANDRADE, J.B.; FERRARI JUNIOR, E.; PAULINO, V.T.; NOGUEIRA, J.R.; BRAUN, G.; CASTRO, F.B. Dry matter yield and nutritive value of coast-cross $n^{\circ}$ 1 preserved as hay, silage and haylage. In: INTERNATIONAL GRASSLAND CONGRESS, 18., Winnipeg; Manitoba; Saskatoon; Saskatchewan, 1997. Resumos. Winnipeg; Manitoba; Saskatoon; Saskatchewan, 1997. v.1, p.14.3-14.4. 
ASSOCIATION OF OFFICIAL ANALYTICAL CHEMISTS. Official methods of analysis. 13. ed. Washington: Association Official Analytical Chemists, v.1, 1980.

BALSALOBRE, M.A.A., NUSSIO, L.G., MARTA JUNIOR,G.B. Controle de perdas de silagens de gramíneas Tropicais. In: REUNIÃO ANUAL DA SOCIEDADE BRASILEIRA DE ZOOTECNIA, 38., Piracicaba, 2001. Anais: A produção animal na visão dos brasileiros. Piracicaba: FEALQ, 2001. p.890-911.

BOIN, C. Formulação de rações para bovinos de corte em confinamento-custo mínimo. Piracicaba: Depto de Zootecnia, ESALQ-USP, p.38, s.d.

CASTILlO, A.R.; BARBI, J.H.; BEEVER, D.E.; SUTTON, J.D.; HUMPHRIES, D.J. Influence of different energy supplements on nitrogen utilisation by dairy cows fed grass silage diets. In: INTERNATIONAL GRASSLAND CONGRESS, 18., Winnipeg, Manitoba; Saskatoon; Saskatchewan; 1997. Resumos. Winnipeg, Manitoba; Saskatoon; Saskatchewan, 1997. p.73.

CASTRO, F.G.F. Uso de pré-emurchecimento, inoculante bacteriano-enzimático ou ácido propiônico na produção de silagem de tifton 85 (Cynodon sp.). Piracicaba, 2002. 136p. Tese (Doutorado) - Escola Superior de Agricultura "Luiz de Queiroz", Universidade de São Paulo.

CASTRO, F.G.F.; NUSSIO, L.G.; SIMAS, J.M.C.; HADDAD, C.M.; TOLEDO, P.; COELHO, R.M.; MARI, L.J. Perfil bacteriológico da silagem de Tifton 85 (Cynodon sp.) sob efeito de pré-emurchecimento e de inoculante bacteriano-enzimatico. In: ANAIS DA REUNIÃO ANUAL DA SOCIEDADE BRASILEIRA DE ZOOTECNIA, 38., Piracicaba, 2001a. Anais Piracicaba: FEALQ, 2001a. p.202-203. 
CASTRO, F.G.F.; NUSSIO, L.G.; SIMAS, J.M.C.; HADDAD, C.M.; TOLEDO, P.; COELHO, R.M.; MARI, L.J. Parâmetros físico-quimicos da silagem de Tifton 85 (Cynodon sp.) sob efeito de pré-emurchecimento e de inoculante bacterianoenzimático. In: ANAIS DA REUNIÃO ANUAL DA SOCIEDADE BRASILEIRA DE ZOOTECNIA, 38., Piracicaba, 2001b. Anais Piracicaba: FEALQ, 2001. p.269270.

CHAMBERLAIN, A.T.; WILKINSON, J.M. Feeding the dairy cow. Lincoln: Chalcomb, 2000. 241p.

CHANEY, A.L.; MARBACH, E.P. Modified reagents for determination of urea and amonia. Clinical Chemistry, v.8. p.130-137, 1962.

CHARMLEY, E.; THOMAS, C. Wilting of herbage prior to ensiling: effects on conservation losses, silage fermentation and growth of beef cattle. British Society of Animal Production, v.45, p.191-203, 1987.

CHURCH, D.C. The ruminant animal digestive phisiology and nutrition. 2.ed. New Jersey: Waveland, 1993. 564p.

COAN, R.M.; VIEIRA, P.F.; SILVEIRA, R.N.; PEDREIRA, M.S; REIS, R.A. Efeitos do inoculante enzimático-bacteriano sobre a composição química, digestibilidade e qualidade das silagens dos capins tanzânia e mombaça. In: ANAIS DA REUNIÃO ANUAL DA SOCIEDADE BRASILEIRA DE ZOOTECNIA, 38., Piracicaba, 2001. Anais Piracicaba: FEALQ, 2001. p.124-126.

COLUCCI, P.E.; MACLEOD, G.K.; GROVUM, W.L.; McMILLAN, I.; BARNEY, D.J. Digesta kinetics in sheep and Cattle fed diets with different forage to concentrate ratios at high and low intakes. Journal of Dairy Science, v.73, p.2143-2156, 1990. 
CORSI, M.; MARTA JUNIOR, G.B. Manejo de pastagens para produção de carne e leite. In: SIMPÓSIO SOBRE MANEJO DE PASTAGEM, 15., Piracicaba, 1998. Anais. Piracicaba: FEALQ, 1998. p.55-84.

CRESTANA, R.F.; AGUIAR, R.N.S.; BALSALOBRE, M.A.A.; NUSSIO, L.G. SANTOS, M.S.; CORSI, M. Efeito da fermentação na fração fibra de silagens de capim tanzânia. . In: ANAIS DA REUNIÃO ANUAL DA SOCIEDADE BRASILEIRA DE ZOOTECNIA, 38., Piracicaba, 2001. Anais Piracicaba: FEALQ, 2001. p.354-355.

DAVIES, D.R.; WERRY, R.J.; BAKEWELL, E.L. The effect of timing of slurry application on the microflora of grass, and changes occurring during silage fermentation. Grass and Forage Science, v.51, p.42-51, 1996.

DAWSON, L.E.R.; FERRIS, C.P.; STEEN, R.W.J.; GORDON, F.J.; KILPATRICK, D.J. The effects of wilting grass before ensiling on silage intake. Grass and Forage Science, v.54, p.237-247, 1999.

DEHORITY, B.A.; TIRABASSO, P.A. Effect of feeding frequency on bacterial and fungal concentrations, $\mathrm{pH}$, and other parameters in the rumen. Journal of Dairy Science, v.79, p.2908-2912, 2001.

DEMARCHI, J.J.A.A. Novo inoculante pode reduzir perdas por fungos e leveduras e pode ser opção econômica. milkpoint.com.br, (6 jan. 2002).

DRIEHUIS, F.; OUDE ELFERINK, S.J.W.H.; SPOELSTRA, S.F. Anaerobic lactic acid degradation during ensilage of whole crop maize inoculated with lactobacillus buchneri inhibits yeast growth and improves aerobic stability. Journal of Applied Microbiology, v.87, p.583-594, june. 1999. 
DRIEHUIS, F.; OUDE ELFERINK, S.J.W.H.;VAN WIKSEAAR, P.G. Fermentation characteristics and aerobic stability of grass silage inoculated with Lactobacillus buchneri alone and in mixture with Pedicocus pentosaceus and lactocillus plantarum. In: GENERAL MEETING OF THE EUROPEAN GRASSLAND FEDERATION, 18., Aalborg, 2000. GRASSLANG FARMING Balance environmental and ecomomic demands. Aalborg: Soegaard, K.; Ohlsson, C.; Sehested, J.; Hutchings, N.J.; Kristensen, T., 2000. p.41-43.

ELLIS, W.C.; POPPI, D.; MATIS, J.H. Feed intake in ruminants: kinetic aspects. In: D MELLO, J.P.F. Farm Animal Metabolism and Nutrition. CAB International, 2000. cap.16, p.335-363.

ERDMAN, R. Silage fermentation characteristics affecting feed intake. In: PROCEEDINGS NATIONAL SILAGE PRODUCTION CONFERENCE, New York, 1993. NRAES-67. New York: Ithaca, 1993. p.210-219.

FARIA, V.P. de Técnicas de Produção de feno. In: PEIXOTO, A.M.; MOURA, J.C.; FARIA, V.P. DE (Ed). Pastagens-Fundamentos da exploração racional. 2 ed. Piracicaba: FEALQ. 1994. p.679-694.

FARIA, V.P. de; CORSI, M. Técnicas de Produção de silagem. In: PEIXOTO, A M.; MOURA, J. C.; FARIA, V. P. DE (Ed) Curso de Alimentação de Bovinos. Ed.: Piracicaba: FEALQ. 1992 .p.165-192.

FERREIRA, L.M.A.; FONTES, C.M.G.A.; FERNANDES, T.H. A fibra em nutrição animal. Revista Portuguesa de Ciências Veterinárias, v.94, n.531, p.119-130, julho/set 1999. 
FILYA, I.; ASHBELL, G.; HEN, Y.; WEINBERG, Z.G. The effect of bacterial inoculants on the fermentation and aerobic stability of whole crop wheat silage. Animal Feed Science and Technology, v.88, p.39-46, Aug., 2000.

FITZGERALD, J.J. Grass silage as a basic feed for store lambs.2.Effect of harvesting system and chop length of grass silage on silage intake and performance of store lambs. Grass and Forage Science, v.51, p.378-388, 1996.

FONTES, C.A.; FERNANDES, T.H.; FERREIRA, L.M.A. Estratégias de degradação biológica da celulose e hemiceluloses. Revista Portuguesa de Ciências Veterinárias, v.91, n. 519, p.106-115, jul/set 1996.

FRANCE, J.; SIDDONS, R.C. Volatile fatty acid production. In: FORBES, J.M.; FRANCE, J. Quantitative aspects of ruminant digestion and metabolism. Wallingford: CAB International, 1993. cap 5, p.107-122.

FIRKINS, J.L; BERGER, L.L.; MERCHEN, N.R.; FAHEY JR, G.C. NELSON, D.R. Effects of feed intake and protein degradability on ruminal characteristics and site of digestion in steers. Journal of Dairy Science, v.86, p.2111-2123, 1996.

FROST, J.P.; POOTS, R.; KNIGHT, A.; GORDON, F.J.; LONG, F.N.J. Effect of forage matting on rate of grass drying, rate of silage fermentation, silage intake and digestibility of silage by sheep. Grass and Forage Science, v.50, p.21-30, 1995.

GOERING, H.K.; VAN SOEST, P.J. Forage fiber analysis. Aparatus, reagents, procedures and some applications. Washington: USDA, 1970. 379p. (ARS Agricultural Handbook) 
GUIMARÃES, K.C.; BRANCO, A.F.; ZEOULA, L.M.; PRADO, I.N.; MOURO, G.F.; MAIA, F.J.; RIGOLON, L.P. Efeito do período experimental sobre a digestão parcial e total em bovinos alimentados com dois níveis de volumosos. Revista Brasileira Zootecnia, v.30, n.3, p.888-896, 2001.

HENRIQUES, L.T.; SILVA, J.F.C.; ESTRADA, L.H.C.; VÁSQUES, H.M.; ARAUJO, G.G.L.; SCÁRDUA, S.S.; BARROS, E.E.L. pH e amônia ruminais de bovinos alimentados com silagem de capim elefante e de milho adicionadas de acipin. In: ANAIS DA REUNIÃO ANUAL DA SOCIEDADE BRASILEIRA DE ZOOTECNIA, 38., Piracicaba, 2001a. Anais Piracicaba: FEALQ, 2001a. p.13221323.

HENRIQUES, L.T.; SILVA, J.F.C.; VÁSQUES, H.M.; ARAUJO, G.G.L.; BARROS, E.E.L.; CECON, P.R.; GOMES, H.L. Efeito do acipin sobre a degradabilidade e a taxa de passagem de silagens de capim elefante e de milho, em bovinos mestiços holandês x zebu ANAIS DA REUNIÃO ANUAL DA SOCIEDADE BRASILEIRA DE ZOOTECNIA, 38., Piracicaba, 2001b. Anais Piracicaba: FEALQ, 2001b. p.1321-1322.

HOLDEN, L.A. Comparison of methods of in vitro dry matter digestibility for ten feeds. Journal of Dairy Science, v.82, p.1791-1794, 1999.

HOLMES, B.J.; MUCK, R.E. Factors affecting bunker silo densities. Madison: University of wisconsin, 1999. $7 \mathrm{p}$.

IGARASI, M.S. Controle de perdas na ensilagem de capim tanzânia (Panicum Maximum jacq. cv Tanzânia) sob os efeitos do teor de matéria seca, do tamanho de partícula, da estação do ano e da presença do inoculante bacteriano. Piracicaba, 2002. 132p. Dissertação (Mestrado) - Escola Superior de Agricultura "Luiz de Queiroz", Universidade de São Paulo. 
KEADY, T.W.J.; STEEN, R.W.J. The effects of treating low dry-matter, low digestibility grass with a bacterial inoculant on the intake and performance of beef cattle, and studies on its mode of action. Grass and Forage Science, v.50, p.217-226, 1995.

KEADY, T.W.J.; O'KIELY, P. An evaluation of the effects of rate of nitrogen fertilization of grassland on silage fermentation, in-silo losses, effluent production and aerobic stability. Grass and Forage Science, v.51, p.350-362, 1996.

KEADY, T.W.J.; MAYNE, C.S. The effects of concentrate energy source on feed intake and rumen fermentation parameters of dairy cows offered a range of grasss silages. Animal Feed Science and Tecnology, v.90, p.117-129, 2001.

KEYSERLINGK, M.A.G. von; SWIFT, M.L.; PUCHALA, R.; SHELFORD, J.A. Degradability characteristics of dry matter and crude protein of forages in ruminants. Animal Feed Science Technology, v.57, p. 291-311, 1996.

KORNDÖRFER, C.M. Eficiência de utilização do feno de Braquiaria decumbens na alimentação de ovinos Santa Inês. Piracicaba, 1999. 110p. Tese (Doutorado) - Escola Superior de Agricultura “Luiz de Queiroz”, Universidade de São Paulo.

KRYSHNAMOORTHY, U.; SNIFFEN, C.J.; STERN, M.D.; VAN SOEST, P.J. Evaluation of a mathemetical model of rumen digestion and in vitro simulation od rumen proteolysis to estimate teh rumen-undegraded nitrogen content od feedstufs. British Journal of Nutrition, v.50, p.555-568, 1983.

KUNG JÚNIOR, L. Aditivos microbianos e químicos para silagem- efeitos na fermentação e resposta animal. In: WORKSHOP SOBRE MILHO PARA SILAGEM, 2., Piracicaba, 2000. Anais Piracicaba: FEALQ, 2000. p.53-73. 
KUNG JÚNIOR, L.; GRIEVE, D.B.; THOMAS, J.W.; HUBER, J.T. Added ammonia or microbial inocula for fermentation and nitrogenous compounds of alfafa ensiled at various percents of dry matter. Journal of Dairy Science, v.67, n.5, p.299-306, May. 1994.

KUNG JÚNIOR, L.; MUCK, R.L. Animal response to silage additives. In: SILAGE: Field to Feedbunk, New York, 1997. NRAES-99. New York: Ithaca,1997. p.200210.

KUNG JÚNIOR, L.; RANJIT, N.K. The effect of Lactobacillus buchneri and other additives on the fermentation and aerobic stability of barley silage. Delaware Agricultural Experiment Station, v.40, p.18, s.d.

KUNG JÚNIOR, L.; TREACHER, R.J.; NAUMAN, G.A.; SMAGALA, A.M.; ENDRES, K.M.; COHEN, M.A. The effect of treating forages with fibrolytic enzymes on its nutritive value and lactation performance of dairy cows. Journal of Dairy Science, v.83, p.115-122, 2000.

LAMBERT, R.J.; STRATFORD, M. Weak-acid preservatives: modelling microbial inhibition and response. The Society for Applied Microbiology, v.86, p.157-164, 1999.

LAMMERS, B.P.; BUCKMASTER, D.R.; HEINRICHS, J. A simple method for the analysis of particle sizes of forage and total mixed rations. Journal of Dairy Science, v.79, n.5, p.922-928, 1996.

LEWIS, G.E.; HUNT, C.W.; SANCHEZ, W.K.; TREACHER, R.; PRITCHARD, G.T.; FENG, P. Effect of direct-fed fibrolytic enzymes on the digestive characteristics of a forage-based diet fed to beef steers. Journal of Dairy Science, v.74, p.3020-3028, 1996. 
LEWIS, G.E.; SANCHEZ, W.K.; HUNT, W.C.; GUY, M.A.; PRITCHARD, G.T.; SWANSON, B.I.; TREACHER, R.J. Effect of direct-fed fibrolytic enzymes on the lactational performance of dairy cows. Journal of Dairy Science, v.82, p.611-617, 1999.

LIMA, M.L.M.; MATTOS, W.R.S.; ROSA, B.; MORAIS, A.M.; SOUZA, R..A Avaliação da distribuição de partículas por tamanhos do milho (Zea mays) colhido para ensilagem. In: ANAIS DA REUNIÃO ANUAL DA SOCIEDADE BRASILEIRA DE ZOOTECNIA, 38., Piracicaba, 2001. Anais Piracicaba: FEALQ, 2001. p.43-44.

LIN, C.; BOLSEN, K K.; BRENT, B.E.; FUNG, D.Y.C. Epiphytic lactic acid bacteria succession during the pre-ensiling and ensiling periods of alfafa and maize. Journal of Applied Bacteriology, v.73, n.9, p.375-387, 1992a.

LIN, C.; BOLSEN, K.K.; HART, R.A.; FEYERHERM, A M.; AIMUTIS, W.R. Epiphytic microflora on alfalfa and whole-plant corn. Journal of Dairy Science, v.75, n.9, p.2484-2493, $1992 b$.

LUCCI, C.S. Nutrição e Manejo de Bovinos Leiteiros. São Paulo: Manole, 1997. p.169.

MAHANNA, W. C. Silage fermentation and additive use in North America. In: PROCEEDINGS NATIONAL SILAGE PRODUCTION CONFERENCE, New York, 1993. NRAES-67. New York: Ithaca, 1993. p.85-95.

MANDEBVU, P.; WEST, J.W.; HARTFIELD, R.D.; HILL, G.M.; FROETSCHEL, A.; GATES, R.N. Effect of enzymes or treatment of bermudagrass forage before ensiling on nutrient composition, recovery and digestion.. Journal of Dairy Science, v.75, p.220, 1997. (Supplement 1). 
MANDEBVU, P.; WEST, J.W.; HARTFIELD, R.D.; HILL, G.M.; FROETSCHEL, A.; GATES, R.N. Effect of treating bermudagrass forages at ensiling with fibrolytic enzymes or microbial inoculant on carbohydrate content of cell walls, concentrations of p-coumaric and ferulic acids, and in situ digestion. Journal of Dairy Science, v.76, p.198, 1998. (Supplement 1).

MARTINS, L.C.T. Bovinos-Volumosos Suplementares. São Paulo: Nobel, 1997. p.143.

MATTOS, W. Alimentos para ruminantes: noções básicas e valor nutritivo: In: PEIXOTO, A.M.; MOURA, J.C.; FARIA, V.P. de, Curso de Alimentação de Bovinos, Piracicaba: FEALQ, 1992. p.53-70.

McALLISTER, T.A.; FENIUK, R.; MIR, Z.: MIR, P.; SELINGER, L.B.; CHENG, K.J. Inoculants for alfafa silage: effects on aerobic stability, digestibility and the growth performance of feedlot steers. Livestock Production Science, v.53, p.171-181, 1998.

McDONALD, P.; HENDERSON, A.R.; HERON, S.J.E. Biochemistry of Silage. 2.ed. Marlow: Chalcombe, 1991. p.340.

MINSON, D.J. Forage in ruminant nutrition. California: Academic Press, 1990. 483p.

MORAIS, J.P.G. Avaliação do efeito de inoculante bacteriano sobre a Qualidade de silagem e desempenho animal. Piracicaba, 1995. 77p. Dissertação (Mestrado) Escola Superior de Agricultura “Luiz de Queiroz”, Universidade de São Paulo.

MUCK, R.E. The role of silage additives in making high quality silage. In: PROCEEDINGS NATIONAL SILAGE PRODUCTION CONFERENCE, New York, 1993. NRAES-67. New York: Ithaca, 1993 p.106-116. 
MUCK, R. E.; KUNG, L. Effects of silage additives on ensiling. In: SILAGE: FIELD TO FEEDBUNK, New York, 1997. NRAES-99. New York: Ithaca, 1997. p.187-199.

NADEAU, E..M.G.; BUXTON, D.R.; RUSSELL, J.R.; ALLISON, M.J.; YOUNY, J.W. Enzyme, bacterial inoculant, and formic acid effects on silage composition of orchardgrass and alfalfa. Journal Dairy Science, v.83, p.1487-1502, 2000.

NATIONAL RESEARCH COUNCIL. Nutrients Requirements of dairy Cattle. 6.ed. Washington: National Academy of Sciences,1989. 157p.

NATIONAL RESEARCH COUNCIL. Nutrients Requirements of Beef Cattle. 7.ed. Washington: National Academy of Sciences, 1996. 242p.

NATIONAL RESEARCH COUNCIL. Nutrients Requirements of dairy Cattle. 7 .ed. Washington: National Academy of Sciences,2001. 381 p.

NOGUEIRA FILHO, J.C.M. Digestão microbiana da parede celular vegetal. In: SIMPÓSIO GOIANO SOBRE MANEJO E NUTRIÇÃO DE BOVINOS, 3., Goiânia, 2001. Anais. Goiânia: SGMNBG, 2001 p.47-74.

NUNES, C.S.; BAPTISTA, A.O. Implicações da reação de Maillard nos alimentos e nos sistemas biológicos. Revista Portuguesa de Ciências Veterinárias, v.96, n. 538, p.53-59, 2001.

NUSSIO, L.G.; HUBER, J.T.; THEURER, C.B.; NUSSIO, C.B.; SANTOS, J.E.R.; TARAZON, M.; LIMA FILHO, R.O.; RIGGS, B.; LAMOREAUX, M.; TREACHER, $\mathrm{R}$. Influence of cellulase/xylanase $(\mathrm{C} / \mathrm{X})$ complex on lactational performance of dairy cows fed alfalfa hay based diets. In: ANNUAL MEETING, 92, Ontário, 1997. ADSA. Ontário:Guelph, 1997. p220. 
NUSSIO, G.N.; MANZANO, R.P.; PEDREIRA, C.G.S. Valor alimentício em plantas do gênero Cynodon. In: SIMPÓSIO SOBRE MANEJO DE PASTAGEM, 15. Piracicaba, 1998. Anais. Piracicaba: FEALQ, 1998. p.203-242.

PALMQUIST, D.L.; CONRAD, H.R. Origin of plasma fatty acids in lactating cows fed high grain fat diets. Journal of Dairy Science, v.54, p.1025, 1971.

PEDREIRA, C.G.S. Avaliação de novas gramíneas do gênero Cynodon para a pecuária dos Estados Unidos. In: WORKSHOP SOBRE O POTENCIAL FORRAGEIRO DO GÊNERO CYNODON. Juiz de Fora, 1996. Anais. EMBRAPA-CNPGL, p. 111-126.

PEDREIRA, M.S.; MOREIRA, AL.; REIS, R.A.; COAN, R.M.; SILVEIRA, R.N.; AZEVEDO, P.T.; SEIXAS, P.F. Características químicas e fermentativas do tifton 85 (Cynodon spp.) ensilado com diferentes conteúdos de matéria seca e níveis de polpa cítrica. In: ANAIS DA REUNIÃO ANUAL DA SOCIEDADE BRASILEIRA DE ZOOTECNIA, 38., Piracicaba, 2001. Anais Piracicaba: FEALQ, 2001. p.100-102.

PEDROSO, A.F.; FREITAS, A.R.; SOUZA, G.B. Efeito do inoculante bacteriano sobre a qualidade da silagem e perda de matéria seca durante a ensilagem de sorgo. Revista Brasileira Zootecnia, v.29, n.1, p.48-52, 2000.

PEIXOTO, A.M.; BOIN, C.; HADDAD, C.M.; BOSE, M.L.V. O Confinamento de bois. 5.ed. São Paulo: Globo, 1988. p.172.

PEIXOTO, A.M. Alimentação de bovinos de corte em confinamento. In: PEIXOTO, A.M.; MOURA, J.C.; DE FARIA, V.P Curso de Alimentação de bovinos. Piracicaba: FEALQ, 1992. p.53-70. 
PEREIRA, E.L.; QUEIROZ, A.C.; NEVES, J.S; MIRANDA，L.F.; DUTRA，A.R.; CAMPELO, I.S.G. Níveis de fibra em dietas de novilhas leiteras.1.consumo e desempenho. In: ANAIS DA REUNIÃO ANUAL DA SOCIEDADE BRASILEIRA DE ZOOTECNIA, 34., Juiz de Fora,1997 Anais Juiz de Fora: SBZ,v.1., 1997. p.521-523.

PEREIRA, M.N.; ARMENTANO, L.E. Efeito da concentração dietética e da origem da fibra sobre o consumo de energia em vacas leiteiras. In: ANAIS DA REUNIÃO ANUAL DA SOCIEDADE BRASILEIRA DE ZOOTECNIA, 34., Juiz de Fora,1997 Anais Juiz de Fora: SBZ,v.1., 1997. p.131-133.

PITT, R.E. Additives for silage and hay preservation. In: SILAGE AND HAY PRESERVATION, New York, 1990a. NRAES-5. New York: Ithaca, 1990. p.28-44.

PITT, R.E. The probability of inoculant effectiveness in alfafa silages. American Society of Agricultural Engineers, v.33, n.6, p.1771-1778, $1990 \mathrm{~b}$.

RABELO, M.M.A.; PIRES, A.V.; TURINO, V.; NUSSIO, L.G.; FERNANDES, J.J.R. Comportamento ingestivo de novilhos de corte alimentados com dietas à base de bagaço de cana de açúcar tratado sob pressão e vapor in natura. In: ANAIS DA REUNIÃO ANUAL DA SOCIEDADE BRASILEIRA DE ZOOTECNIA, 38., Piracicaba, 2001. Anais Piracicaba: FEALQ, 2001. p.1060-1061.

RAYMOND, F.; REDMAN, P.; WALTHAM, R.. Principles of forage conservation. In: RAYMOND, F. Forage conservation and feeding. 4.ed. Marlow: Farm Press, 1986. p.64

REIS, R.A.;RODRIGUES, L.R..A. Aditivos para produção de fenos. In: REUNIÃO ANUAL DA SOCIEDADE BRASILEIRA DE ZOTECNIA, 35., Botucatu,1998. Anais. Botucatu: SBZ, 1998. p.109-152. 
RIBEIRO, K.G. Rendimento forrageiro e valor nutritivo do capim Tifton 85, sob diferentes doses de nitrogênio e idades de rebrota,e na forma de feno, com bovinos. Viçosa, 2000. 106 p. Dissertação (Doutorado)- Universidade Federal de Viçosa.

RIBEIRO, K.G.; PEREIRA, O.G.; VALADARES, S.C.F.; GARCIA, R; CABRAL, L.S. Caracterização das frações que constituem as proteínas e os carboidratos, e respectivas taxas de digestão, do feno de capim-tifton 85 de diferentes idades de rebrota. Revista Brasileira Zootecnia, v.30, n.2, p.589-595, $2001 \mathrm{a}$.

RIBEIRO, K.G.; PEREIRA, O.G.; VALADARES, S.C.F.; GARCIA, R; CECON, P.R. Consumo e digestibilidades aparentes total e parcial, de nutrientes, em bovinos recebendo rações contendo feno de capim-tifton 85 de diferentes idades de rebrota. Revista Brasileira Zootecnia, v.30, n.2, p.573-580, 2001 b.

RIBEIRO, K.G.; PEREIRA, O.G.; VALADARES, S.C.F.; GARCIA, R; CECON, P.R. Eficiência microbiana, fluxo de compostos nitrogenados no abomaso, amônia e pH ruminais, em bovinos recebendo dietas contendo feno de capim-tifton 85 de diferentes idades de rebrota. Revista Brasileira Zootecnia, v.30, n.2, p.581-588, $2001 \mathrm{c}$.

ROCHA, M.H.M. da; SUSIN, I.; PIRES, A.V.; FERNANDES, R.H.R.; NUSSIO, L.G; CASTRO, F.G.F. Uso de silagem pré-emurchecida de Tifton 85 (Cynodon spp.) para cabritos em crescimento. In: ANAIS DA REUNIÃO ANUAL DA SOCIEDADE BRASILEIRA DE ZOOTECNIA, 38 ., Piracicaba, 2001. Anais Piracicaba: FEALQ, 2001. p.1071-1072.

RODRIGUES, L.R.A.; REIS, R.A.; FILHO, C.V.S. Estabelecimento de pastagens de Cynodon. In: SIMPÓSIO SOBRE MANEJO DE PASTAGEM, 15., Piracicaba, 1998. Anais. Piracicaba: FEALQ, 1998. p.115-128. 
RODRIGUES, P.H.M.; ANDRADE, S.J.T.; ALMEIDA, L.F.S.; MEYER, P.M.; LIMA, F.R.; LUCCI, C.S. Valor nutritivo de silagens inoculadas com bactérias ácido láticas. 5. inoculação da silagem de alfafa. In: ANAIS DA REUNIÃO ANUAL DA SOCIEDADE BRASILEIRA DE ZOOTECNIA, 38., Piracicaba, 2001. Anais Piracicaba: FEALQ, 2001a. p.916-918.

RODRIGUES, P.H.M.; ANDRADE, S.J.T.; ALMEIDA, T.F.; MEYER, P.M.; MELOTTI, L. Valor nutritivo de silagens inoculadas com bactérias ácido láticas. 3. inoculação da silagem de girasol. In: ANAIS DA REUNIÃO ANUAL DA SOCIEDADE BRASILEIRA DE ZOOTECNIA, 38., Piracicaba, 2001. Anais Piracicaba: FEALQ, 2001b. p.915-916.

RODRIGUES, P.H.M.; ANDRADE, S.J.T.; FERNANDES, T.; LIMA, F.R.; MELOTTI, L. LUCCI, C.S. Valor nutritivo de silagens inoculadas com bactérias ácido láticas. 4. inoculação da silagem de capim efefante. In: ANAIS DA REUNIÃO ANUAL DA SOCIEDADE BRASILEIRA DE ZOOTECNIA, 38., Piracicaba, 2001. Anais Piracicaba: FEALQ, 2001c. p.911-912.

RODRIGUES, P.H.M.; ANDRADE, S.J.T.; RUZANTE, J.M.; LIMA, F.R.; MELOTTI, L. Valor nutritivo de silagens inoculadas com bactérias ácido láticas. 1. inoculação da silagem de milho. In: ANAIS DA REUNIÃO ANUAL DA SOCIEDADE BRASILEIRA DE ZOOTECNIA, 38., Piracicaba, 2001d. Anais Piracicaba: FEALQ, 2001d. p.920-921.

RODRIGUES, P.H.M.; SENATORE, A.L.; LUCCI, C.S.; ANDRADE, S.J.T.; LIMA, F.R.; MELOTTI, L. Valor nutritivo de silagens inoculadas com bactérias ácido láticas. 2. inoculação da silagem de sorgo. In: ANAIS DA REUNIÃO ANUAL DA SOCIEDADE BRASILEIRA DE ZOOTECNIA, 38., Piracicaba, 2001. Anais Piracicaba: FEALQ, 2001e. p.918-920. 
ROOK, A.J.; GILL, M. Prediction of the voluntary intake of grass silages by beef cattle.1. linear regression analyses. Animal Production, v.50: p.425-438, 1990.

ROOKE, J.A. The numbers of epiphitic bacteria on grass at ensilage on commercial farms. Journal of the Science of Food and Agriculture, v.51, p.525-533, 1990.

RUXTON, G.D; GIBSON, G.J. A mathematical model of the aerobic deterioration of bigbale silage and its implications for the growth of Listeria monocytogenes. Grass and Forage Science, v.50, p.331-344, 1995.

SAS INSTITUTE. SAS USER'S GUIDE, REALESE 6.0.3. Cary, 1988. 1028 p.

SHINNERS, K.J.; JIROVEC, A.G.; SHAVER, R.D.; BAL, M. Processing wilted alfafa with crop processing rolls on a pull-type forage harvester American Society of Agricultural Engineers, v.16, n.4, p.333-340, 2000.

SILVA, A.W.L. da; MACEDO, A.F.; MIQUELLUTI, D.J.; NETO, W.H. Efeito do uso de inoculante bacteriano e diferentes proporções de grãos na massa sobre a composição bromatológica da silagem de milho. In: ANAIS DA REUNIÃO ANUAL DA SOCIEDADE BRASILEIRA DE ZOOTECNIA, 34, Juiz de Fora,1997 Anais Brasília: SBZ, 1997. v.1. p.170-172.

SOUZA, V.G.; PEREIRA, O.G.; FILHO, S.C.V.; RIBEIRO, K.G.; MORAES, S.A. Consumo, ganho de peso e conversão alimentar de bovinos de corte recebendo rações à base de silagem de sorgo e pré-secado de capim Tifton 85 In: ANAIS DA REUNIÃO ANUAL DA SOCIEDADE BRASILEIRA DE ZOOTECNIA, 38., Piracicaba, 2001. Anais Piracicaba: FEALQ, 2001. p.1237-1238. 
STEEN，RW.J.; GORDON，F.J.; DAWSON，L.E.R.; PARK，R.S.; MAYNE，C.S.; AGNEW, R.E.; KILPATRICK, D.J.; PORTER, M.G. Factors affecting the intake of grass silage by cattle and prediction of silage intake. Journal of Animal Science, v.66, p.115-127, 1998.

THIAGO, L.R.L.S. Fatores afetando o consumo e utilização de forrageiras de baixa qualidade por ruminantes. Campo Grande: EMBRAPA-CNPGC, 1984 . 35p. (Documentos, n.9).

THIAGO, L.R.L.S.; GILL, M. Consumo Voluntário: fatores relacionados com a degradação e passagem da forragem pelo rúmen. Campo Grande: EMBRAPACNPGC, 1990. 65p. (Documentos, n.43).

THOMAS, P.C.; CHAMBERLAIN, D.G. Silage as a foodstuff. In: ROOK, J.A.F.; THOMAS, P.C. Silage for Milk Production. London: chalcomb, 1992. (Technical Bulletin 2).

TOSI, P.; MATTOS, W.R.S.; TOSI, H.; JOBIM, C.C.; LAVEZZO, W. Avaliação química e microbiana da silagem do capim-elefante CV TAIWAN A-148, sob diferentes técnicas de redução de umidade. In: REUNIÃO ANUAL DA SOCIEDADE BRASILEIRA DE ZOOTECNIA, 34:, Juiz de Fora,1997 Anais Juiz de Fora: SBZ,v.1., 1997. p.206-208.

TRIOPLAST AB. The bale wrapping handbbok. Smalandsstenar: TRIOPLAST AB, 1995. 52p.

UDÉN, P.; COLUCCI, P.E.;VAN SOEST, P.J. Investigation of chromium, cerium, and cobalt as markers in digesta. Rate of passage studies. Journal of the Science of food and Agriculture, v.31, p.625-632, 1980. 
UMANÃ, R.; STAPLES, C.R.; BATES, D.B.; WILCOX, C.J.; MAHANNA, W.C. Effects of a digestibility of bermudagrass ensiled at two moisture contents. Journal of Animal Science, v.69, p.4588-4601, 1991.

VAN SOEST, P.J. Nutritional Ecology of The Ruminant. 2.ed. New York: Cornell University Press, 1994. 476p.

VAN SOEST, P.J.; ROBERTSON, J.B.; LEWIS, B.A. Methods for dietary fiber, neutral detergent fiber, and nonstarchch polysaccharides in relation to animal nutrition. Journal of Dairy Science, v.74, n.10, p 3583, 1991.

VARGAS, G.A.; KOLVER, E.S. Microbial and Animal Limitations to Fiber Digestion and Utilization. American Society for Nutritional Sciences,v.127, p.819S-823S, 1997. (Suplemento). Resumo Apresentado ao 37th Annual Ruminant Nutrition Conference "New Developments in Forage Science Contributing to Enhanced Fiber Utilization by Ruminants”, Washington, 1996.

VILELA, D. Aditivos na ensilagem Coronel Pacheco: EMBRAPA-CNPGL, 1984. 32p. (Circular Técnica, 21).

VILELA, D. Avaliação nutricional da silagem de capim-elefante (Pennisetum purpureum, Schum) submetido a emurchecimento e adição de ureia na ensilagem. Viçosa, 1989. 186p. Tese(Doutorado)-UFV, Universidade Federal de Viçosa.

VILELA, D. Aditivos para silagens de plantas de clima tropical. In: REUNIÃO ANUAL DA SOCIEDADE BRASILEIRA DE ZOTECNIA, 35., Botucatu,1998. Anais. Botucatu: SBZ, 1998. p.73-108. 
VILELA, D. Utilização do capim- elefante na forma de forragem conservada. CapimElefante: Produção e Utilização. Coronel Pacheco: EMBRAPA-CNPGL, 1994. p. $117-164$

VILELA, H.; BARBOSA, F.A.; DIAS, E.T.; RODRIGUES, N.; BENEDETTI, E. Qualidade das silagens de capim elefante paraíso (Pennisetum hybridum cv. Paraíso) submetidas a três tempos de emurchecimento. In: ANAIS DA REUNIÃO ANUAL DA SOCIEDADE BRASILEIRA DE ZOOTECNIA, 38., Piracicaba, 2001. Anais Piracicaba: FEALQ, 2001. p.323-324.

WALLACE, R.J.; WALLACE, S.J.A.; MCKAIN, N.; NSEREKO, N.L.; HARTNELL, G.F. Influence of supplementary fibrolytic enzymes on the fermentation of corn and grass silages by mixed ruminal microorganisms in vitro. Journal of Animal Science, v.79, p.1905-1916, 2001.

WALLACE, R.J; HARTNELL, G.F. Technical note: methods for detecting liquid enzyme additives added to animal feeds. Journal of Dairy Science, v.79, p 2731-2735, 2001.

WEINBERG, Z.G.; ASHBELL, G.; BOLSEN, K.K.; PAHLOW, G.; YAIRA, H.; AZRIELLI, A. The effect of propionic acid bacterial inoculant applied at ensiling, with or without lactic acid bacteria, on aerobic stability of pearl millet and maize silages. Journal of Applied Bacteriology, v.78, p. 43-436, 1995.

WEINBERG, Z.W.; MUCK, R.E. New trends and opportunities in the development and use of inoculants for silage. FEMS Microbiology reviews, v.19, p.53-68, july. 1996.

WELCH, J.G. Rumination, particle size and passage from the rumen. Journal of Animal Science, v.54, n.4, p.885-894, 1982. 
WELCH, J.G. Physical parameters of fiber affecting passage from the rumen. Journal of Dairy Science, v.69, p 2750-2754, 1986.

WILKINSON, J. M. Beef production from silage. New York: Longman, 1985. 137p.

WILKINSON, J.M. Additives for ensiled temperate crops. In: REUNIÃO ANUAL DA SOCIEDADE BRASILEIRA DE ZOTECNIA, 35., Botucatu,1998. Anais. Botucatu: SBZ, 1998. p.53-72.

WRIGHT, D.A.; GORDON, F.J.; STEEN, R.W.J.; PATTERSON，D.C. Factors influencing the response in intake of silage and animal performance after wilting of grass before ensiling: a review. Grass and Forage Science, v.55, p.1-13, 2000.

YAN, T.; GORDON, F.J.; DAWSON, L.E.R.; FERRIS, C.P.; STEEN, R.W.J.; KILPATRICK, D.J. The effect of wilting and type on energy utilization of grass silage by growing cattle. In: INTERNATIONAL GRASSLAND CONGRESS, 18., Winnipeg, Manitoba; Saskatoon; Saskatchewan, 1997. Resumos. Winnipeg, Manitoba; Saskatoon; Saskatchewan, 1997. v.1, p.14.3-14.4.

YANG, W.Z.; BEAUCHEMIN, K.A.; RODE, L.M. A Comparison of Metodos of Adding Fibrolytic Enzymes to Lactating Cow Diets. Journal of Dairy Science, v.83, p 2512$2520,2000$. 